\title{
Alaska Division of Geological \& Geophysical Surveys \\ ANNUAL REPORT 2017
}

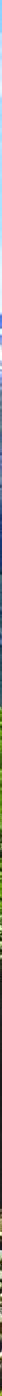




\section{STATE OF ALASKA}

Bill Walker, Governor

\section{DEPARTMENT OF NATURAL RESOURCES}

Andrew T. Mack, Commissioner

\section{DIVISION OF GEOLOGICAL \& GEOPHYSICAL SURVEYS}

Steve Masterman, State Geologist and Director

Publications produced by the Division of Geological \&

Geophysical Surveys (DGGS) are available to download from the

DGGS website (dggs.alaska.gov). Publications on hard-copy or

digital media can be examined or purchased in the Fairbanks

office:

\section{Alaska Division of Geological \& Geophysical Surveys}

3354 College Rd., Fairbanks, Alaska 99709-3707

Phone: (907) 451-5010 Fax (907) 451-5050

dggspubs@alaska.gov | dggs.alaska.gov

\section{DGGS publications are also available at:}

Alaska State Library,

Historical Collections \& Talking Book Center

395 Whittier Street

Juneau, Alaska 99811

Alaska Resource Library and Information Services (ARLIS)

3150 C Street, Suite 100

Anchorage, Alaska 99503

\section{Suggested citation:}

DGGS Staff, 2018, Alaska Division of Geological \& Geophysical Surveys Annual

Report 2017: Alaska Division of Geological \& Geophysical Surveys Annual Report

2017, 51 p. http://doi.org/10.14509/29844

\section{Statutory Authority}

Alaska Statutes Sec. 41.08.010. Division of geological and geophysical surveys. There is established in the Department of Natural Resources a Division of geological and geophysical surveys under the direction of the state geologist. (1 ch 93 SLA 1972)

Sec. 41.08.015. State geologist. The commissioner of natural resources shall appoint the state geologist, who must be qualified by education and experience to direct the activities of the Division. (1 ch 93 SLA 1972)

Sec. 41.08.020. Powers and duties. (a) The state geologist shall conduct geological and geophysical surveys to determine the potential of Alaskan land for production of metals, minerals, fuels, and geothermal resources; the locations and supplies of groundwater and construction materials; the potential geologic hazards to buildings, roads, bridges and other installations and structures; and shall conduct such other surveys and investigations as will advance knowledge of the geology of Alaska. With the approval of the commissioner, the state geologist may acquire, by gift or purchase, geological and geophysical reports, surveys and similar information.

Sec. 41.08.030. Printing and distribution of reports. The state geologist shall print and publish an annual report and other special and topical reports and maps as may be desirable for the benefit of the State, including the printing or reprinting of reports and maps made by other persons or agencies, where authorization to do so is obtained. (1 ch 93 SLA 1972)

Sec. 41.08.045. Fees for facilities, equipment, products and services. The division of geological and geophysical services may charge and collect a fee for facilities, equipment, products or services that the division offers.
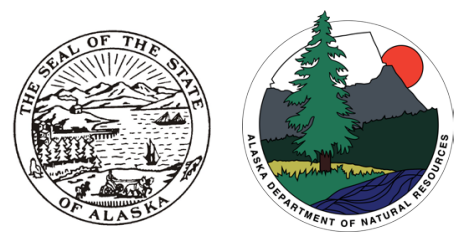

Cover: Alaska Division of Geological \& Geophysical Surveys (DGGS) geologist Alicja Wypych collects samples for geochemical analysis in support of 1:63,360-scale bedrock geologic mapping in the Tuxedni Bay area of lower Cook Inlet as part of the Cook Inlet basin analysis program. Geologic mapping and associated studies in the region by DGGS since 2013 has resulted in important new insights into the stratigraphic and structural framework of the basin margin that help to improve upon the understanding of its petroleum system. 


\section{FROM THE DIRECTOR...}

Greetings! I am always amazed by the quality and quantity of work completed by the staff at Alaska's geological survey, or DGGS as we like to call it. Whether it's mapping coastal flooding, issuing volcano eruption alerts to communities and aviators, making mineral and energy maps and reports which bring in revenue to the Alaska Permanent Fund, the work done by DGGS staff touches the lives of all Alaskans. This annual report is a brief summary of the many achievements of these energetic, resourceful, and committed staff:

- On September 1, 2017, DGGS released its milestone 5,000th publication, and has now produced a publication, on average, every four business days since statehood in 1959.

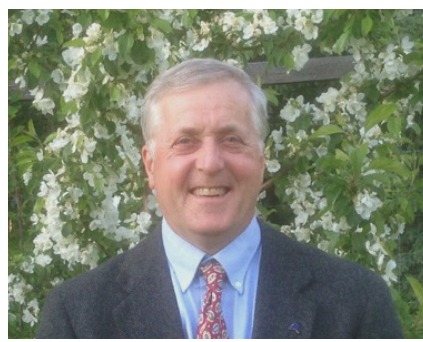

- DGGS petroleum geologists discovered a >100 foot-thick oil-stained sandstone interval in the Jurassic Tonnie Siltstone during field work in lower Cook Inlet. This exposure appears to be oil stained throughout, and the size suggests the potential for conventional oil reservoirs in these strata.

- DGGS petroleum geologists led a half-day core workshop focusing on the oil and gas reservoir potential of the North Slope Nanushuk Formation, attended by more than 40 geologists from the oil and gas industry, and led a three-day oil and gas field trip for industry geologists focusing on the geology of northern Alaska, including key Torok and Nanushuk Formation outcrops.

- DGGS minerals geologists completed the first phase of geologic mapping and geochemical sampling for mineral assessments of parts of the Tanacross and Big Delta quadrangles, which are prospective for lode gold and porphyry gold-copper-molybdenum systems.

- Mineral resources geologists published new, detailed geologic mapping and geochemical sampling in the Tok River area, and documented 20 new mineral occurrences. Following these DGGS publications, industry staked about 68,700 acres of mining claims on state land in the area.

- The DGGS Coastal Program established new flooding/erosion monitoring stations to measure the impacts of storms on Alaska's western coast. DGGS personnel visited 17 communities and collaborated with local tribal and city governments to establish erosion and flood monitoring sites throughout Alaska, and trained local residents to conduct regular monitoring activities.

- The DGGS Coastal Program was awarded a Digital Coast Fellow, a 2-year NOAA-funded position.

- More than 60 explosive events during the 2016-2017 eruption of Bogoslof volcano consumed much of DGGS-Alaska Volcano Observatory's (AVO) staff time. DGGS-AVO eruption response tasks included tracking ash cloud movement; issuing aviation alerts; keeping records of eruptions, pilot reports, and volcano monitoring data; responding to media requests; providing community ash fall preparedness presentations; and keeping the public informed of volcanic activity and hazards.

- DGGS website received 29.7 million page-views and recorded more than 1.2 million downloads of DGGS reports and datasets.

- The Geologic Materials Center (GMC) began collecting fees for services, including fees for 2-D and 3-D tax credit seismic surveys, and is now a revenue-generating facility for the State.

- The number of client visits to the GMC is estimated at 1,090 persons for 2017, a 58 percent increase over 2016. This included core workshops and Congressional and Chinese delegations.

These snapshots are just a few of the notable DGGS achievements during the last year. I encourage you to read this report and learn more about Alaska's geological survey and its projects, activities, products, and impacts. Investing in geologic information is necessary for the discovery and commercialization of the State's undiscovered oil, gas, coal and mineral resources, and for protecting Alaskans from geologic hazards. It is an investment in future mines, oil and gas production, state revenue, jobs, and a sound economy.

Respectfully,

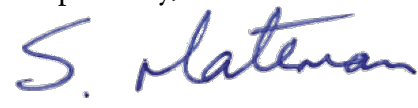

Steven S. Masterman

State Geologist \& Director 


\section{TABLE OF CONTENTS}

KEY ISSUES

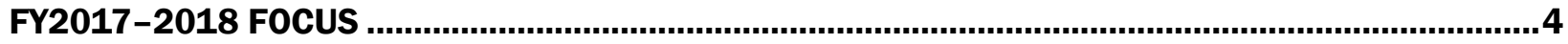

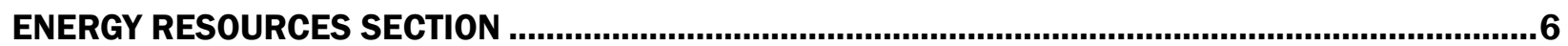

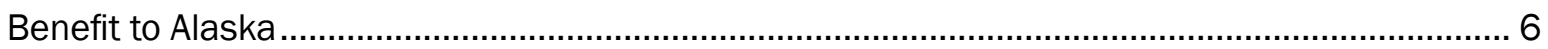

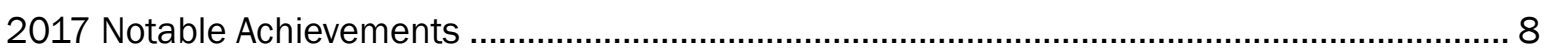

Energy Resources 2017 Publications....................................................................................... 9

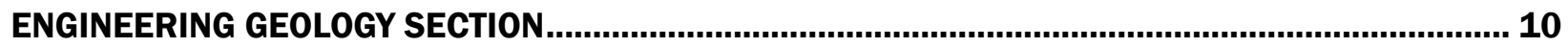

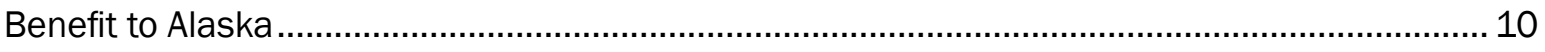

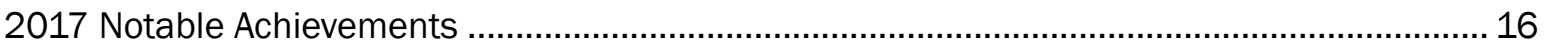

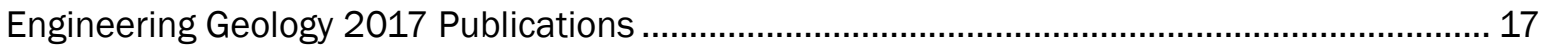

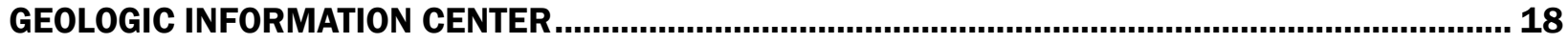

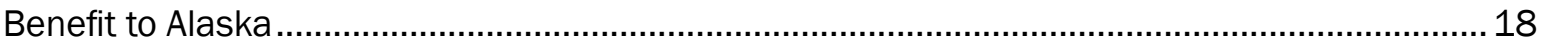

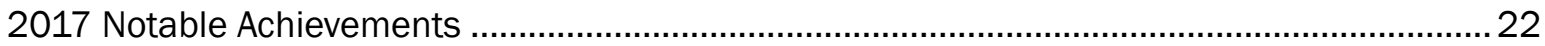

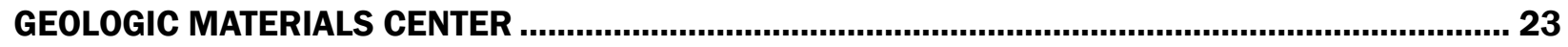

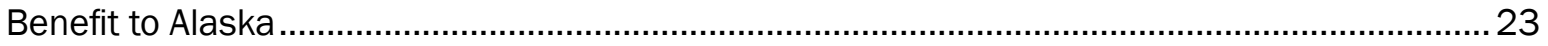

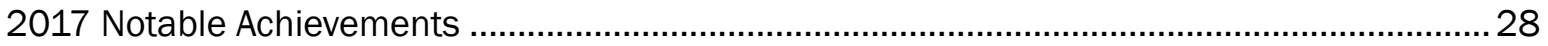

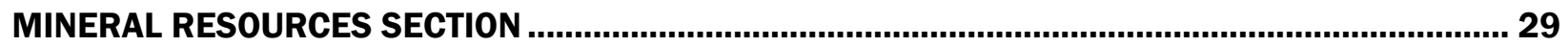

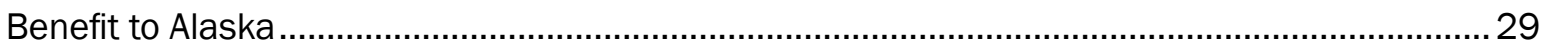

Feature Story: DGGS Project Spurs Exploration Activity in the Tok River Area..........................30

Minerals Resources 2017 Publications ........................................................................................ 34

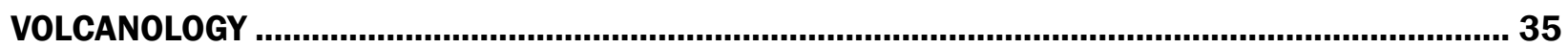

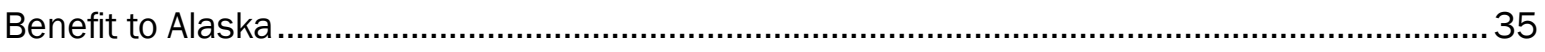

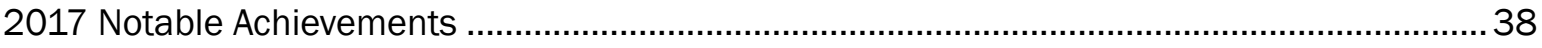

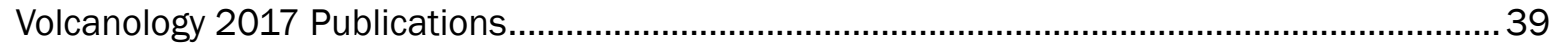

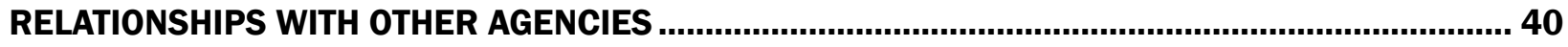

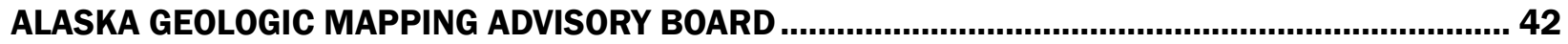

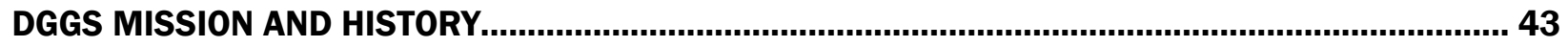

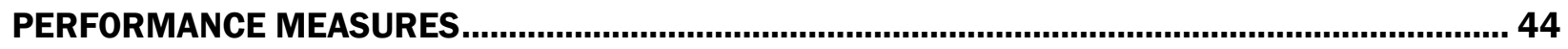

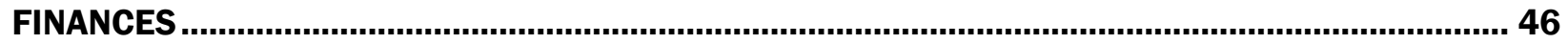

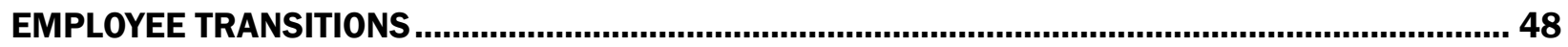

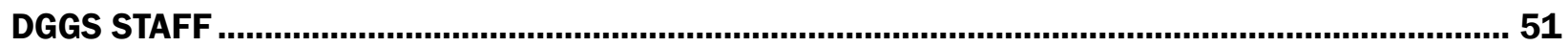




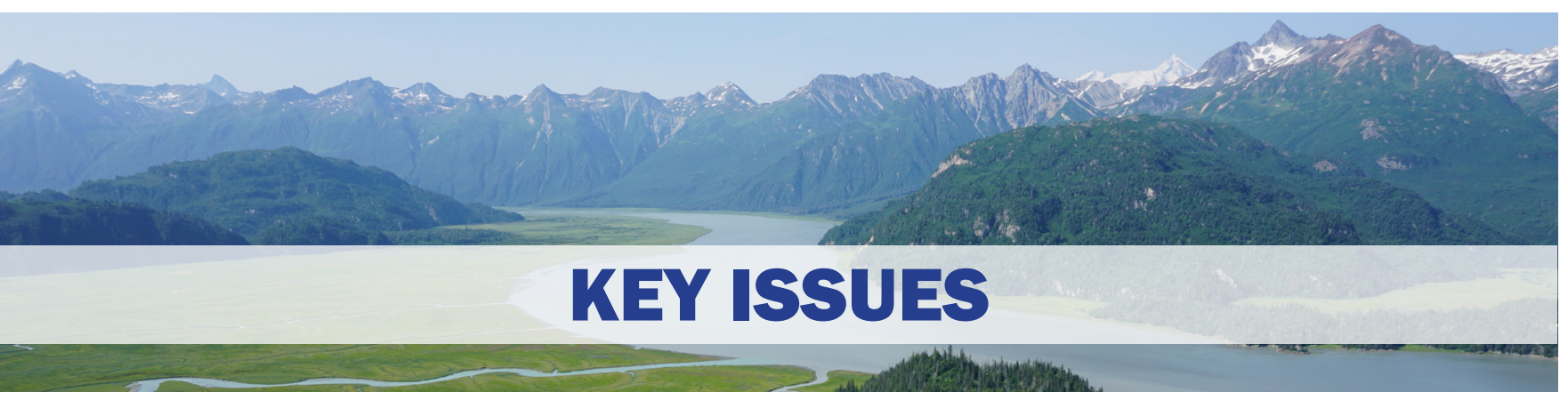

DGGS faces numerous critical issues and has to determine the strategic allocation of available resources to balance the needs of the broader state economy with those of local communities, all while ensuring that we fulfill our mission.

One of the largest challenges DGGS faces is being undersized, relative to the size of Alaska. This translates into a limited capacity to fulfill our mission in a functional amount of time. As an example, the rate of geological mapping over the last 20 years indicates it will take DGGS at least another 400 years to complete a geologic map of the state at a 1-inch to 1-mile scale. Geologic maps are fundamental data for all energy and mineral development, engineering geology, geologic hazards, groundwater and construction materials investigations. Similar time scales apply to other basic types of geologic data needed to fulfill the division's mission. Our rate of progress needs to accelerate for the state to achieve the potential inherent in its energy and mineral resources, and to assist communities with hazard planning in a reasonable timeframe.

\section{OIL AND GAS DEVELOPMENT}

Recent discoveries on Alaska’s North Slope have resulted in the U.S. Geological Survey (USGS) updating their assessments of undiscovered oil. The USGS' revised NPR-A oil and gas assessment concludes that there are billions of barrels of oil yet to discover. The North Slope and Cook Inlet are both mature hydrocarbon basins and, like all mature hydrocarbon basins, the "easy" prospects are drilled and tested early, with the untested, remaining plays requiring new geologic research and investment to maintain discovery and production rates. Industry use of DGGS reports and samples illustrate the value in making and keeping high-quality geologic data available. New geologic information is the key to advancing understanding of the petroleum systems and ensuring new resource discoveries. DGGS will continue to be challenged to provide sufficient new information to stimulate the development of these new and varied resource types.

The bulk of energy exploration and development is focused in two areas, the North Slope and Cook Inlet. Many other areas in Alaska have hydrocarbon potential, but are currently not being explored. DGGS will be challenged to continue to provide sufficient geologic information to attract exploration into inactive hydrocarbon basins.

\section{MINERAL DEVELOPMENT}

It is the Governor's goal to double the number of large mines in Alaska. Alaska's mineral potential is ranked high, but its mid-tier rank for the quality of its geologic datasets inhibits exploration, and prevents the state from fully realizing its mineral potential. Improving these datasets will help make Alaska more attractive to the exploration industry. Knowing that exploration precedes discovering and development, DGGS will be severely challenged to provide the necessary geology, geophysics, and geochemistry datasets to position Alaska to meet this goal in a timely manner with currently available resources. DGGS welcomes this challenge and will be doing everything possible to meet the needs of the industry.

Rapidly changing technology results in rapid changes in commodity needs. This situation creates a fluid and evolving commodities market with rapid price adjustments to changing metal needs. DGGS will be challenged to provide sufficient new data and interpretations related to the occurrence of emerging commodities in a timely manner for industry to respond to these new demands. DGGS will also be challenged to be forward-looking, anticipating the 
demands for geoscience data and quickly responding to surges in demand for commodity-specific geoscience data during commodity price fluctuations.

\section{PUBLIC SAFETY AND COMMUNITY RESILIENCE}

Despite Alaska's abundance of geologic hazards, such as earthquakes, tsunamis, volcanoes, landslides, avalanches, and others, there is a grave lack of systematic, statewide data to allow quick assessment of natural hazards risks. Communities, residents, project proponents, and managers alike suffer from this lack of basic data. Providing basic statewide geologic hazards data will remain a key challenge and priority for DGGS.

Geologic information is needed in a number of key community resiliency efforts. These data are essential for coastal and river communities, which can be impacted by thawing permafrost, erosion, storm surges, landslides, sea-level change, and changes in the hydrologic system. DGGS will be challenged to continue its efforts to provide basic information to guide community and regional resiliency efforts.

The state has historically relied on site-specific hazard analyses related to ongoing development or permit approval. There is a growing need for up-todate, regional or statewide baseline data. DGGS will be challenged to provide these data before they are required to manage crisis situations.

Construction materials are in critically short supply in numerous areas of the state and the lack of affordable basic construction materials can dramatically affect project economics, making some projects uneconomic or unaffordable. Meeting this need for information will continue to be a challenge for DGGS.

\section{LOCAL ENERGY SUPPLY}

Energy prices are climbing once again, and high energy prices have a significant impact on the economy of rural Alaska and threaten the viability of rural communities. Many remote areas of the state lack sufficient geologic information about potential alternate forms of local energy, such as shallow natural gas, coal, geothermal, and conventional gas resources. The cost associated with developing these alternative energy forms is often prohibitive on a small scale but, in some cases, it will be necessary to replace even higher-cost diesel fuel. Providing targeted geologic data to help local governments understand the locally available resources, and the development challenges associated with them, will remain a key challenge. DGGS will be challenged to provide pertinent and timely data on numerous fronts, and to address the occurrence of locally available energy sources. DGGS will continue to strive to make data available to those who need it, moving Alaska toward a more secure and affordable energy future.

\section{THE CHANGING ARCTIC CLIMATE}

Destabilized permafrost from continued Arctic warming will increase maintenance costs for Alaska’s buildings, rail, highway, and airport systems. Identifying geologic hazards and areas prone to ground failure will be necessary to mitigate these changes. Impacts from climate change will be most extreme in coastal, low-lying areas, and areas that will be destabilized by thawing of permafrost.

The Arctic has warmed at twice the rate of the rest of the planet since 1900. DGGS geoscientists are playing a leading role in guiding climate change research in the Arctic. The expansion of Arctic shipping lanes from Asia to Europe highlight the paucity of basic coastal and maritime data along Alaska's western and northern coasts. As the nation's only Arctic state geological survey, DGGS will be challenged to guide research to provide the necessary data on coastal and nearshore areas, address the effects of Arctic climate change, and identify areas of critical need for the state.

Alaska will be an international focal point for indications and impacts of climate change. DGGS's ability to guide, and provide reliable, unbiased data for the development and evaluation of emerging policy and statute changes will be challenged. A key objective will be prioritization; because of Alaska's large size and the lack of existing data, the need for data is greater than the amount of personnel and funding required to generate it. DGGS will be challenged to continue developing and applying innovative methods and technologies for data acquisition and analysis. 


\section{ACCESS TO ALASKA'S GEOLOGIC MATERIALS AND INFORMATION}

Our ability to provide geologic data to exploration and development industries will be tested as users demand comprehensive information to be delivered more quickly. The Geologic Materials Center (GMC) is a key component of these efforts and is the "first stop" for oil and gas and mineral exploration companies.

Digital mapping techniques, changes in database design, vast volumes of data, and ever-changing computer software and hardware are a challenge to DGGS' ability to meet an increasingly diverse customer base. Paper maps and reports are no longer sufficient; digital maps, databases, social media, and interactive online maps are among our growing list of distribution methods that are all crucial in an increasingly electronic world. DGGS must continue developing and optimizing its data acquisition, storage, and distribution programs to discover and provide new and more efficient ways to disseminate the information to the groups who use it.
The state's archive of geologic materials represents billions of dollars of acquisition and preservation costs. Providing efficient and comprehensive access to this collection is critically important for viable exploration programs, for both seasoned and new Alaska exploration companies. Any one piece of core from this archive has the potential to identify a resource prospect that could bring billions of dollars of revenue to the state. DGGS will be challenged to secure funding to ensure the facility continues to operate, grow, generate revenue, and serve its users long into the future.

\section{PERSONNEL RETENTION AND RECRUITMENT}

Cyclical commodity prices create spikes in the exploration cycle, which creates challenges for DGGS. However, low commodity prices will not persist indefinitely. During boom times, high-paying, private-sector jobs become abundant, and opportunities for experienced geoscientists become commonplace. The state must remain competitive in workforce recruitment and keep our best and brightest employees.

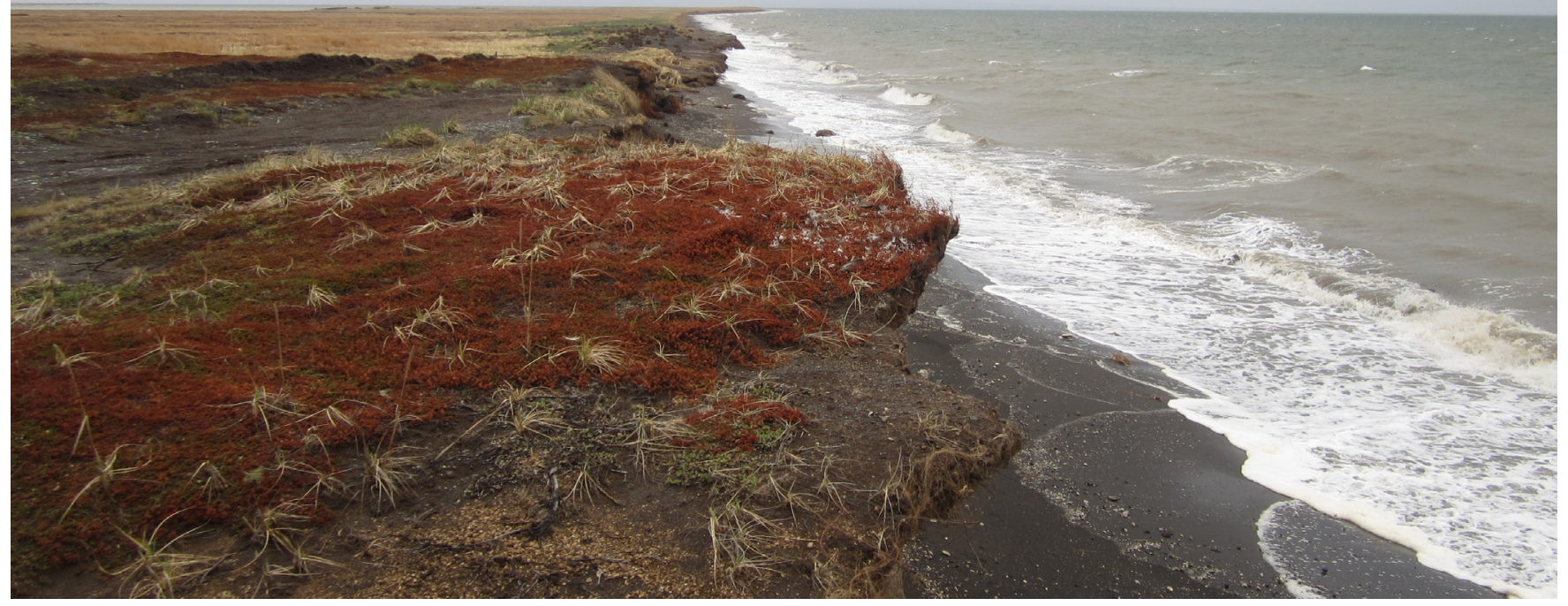




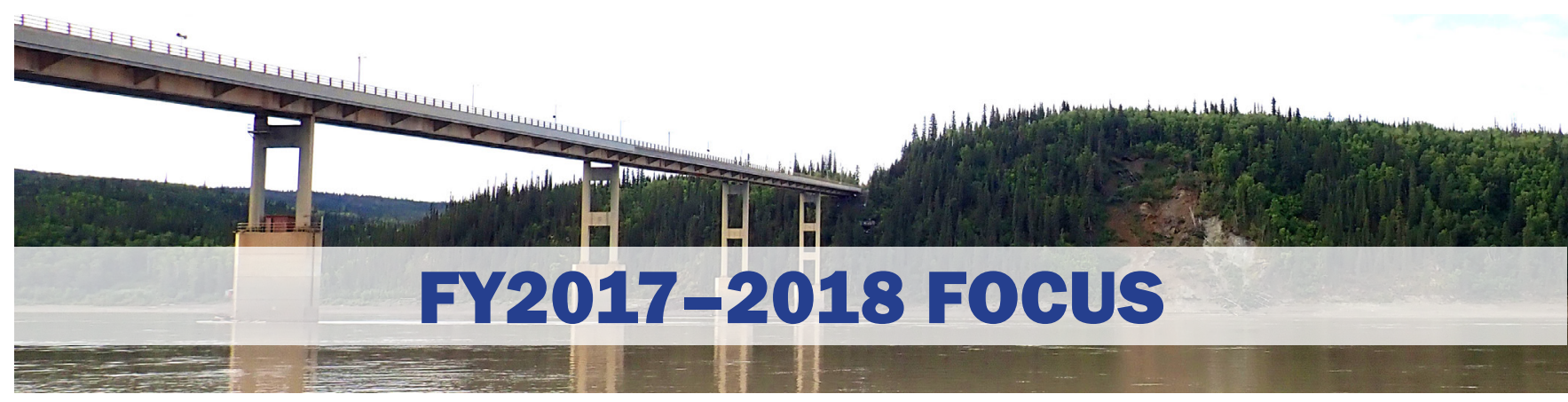

DGGS is a strategic investment in future state revenue generation and the maintenance of Alaska's economy. Our agency provides objective geologic information to assist energy and mining companies discover and develop Alaska's oil, gas, and mineral resources. DGGS also provides information about construction materials and groundwater, which are critical to developing these economic resources, and evaluates geologic hazards that may adversely impact the state's economy and public safety. DGGS will continue to be the central repository of information on Alaska's resources and will play a pivotal role in their commercialization. DGGS will continue to conduct geologic hazard research to provide a scientific basis for community hazard mitigation efforts.

\section{GOALS FOR THE UPCOMING YEAR INCLUDE:}

\section{Energy Resources}

- Continue providing highly relevant geologic maps and reports for the Cook Inlet and North Slope basins to stimulate resource discovery in the state's primary oil and gas basins.

- Provide new information that highlights the exploration potential of frontier, underexplored, or inactive basins.

- Provide new geologic information on the state's vast and diverse unconventional energy resources.

- Release new geology maps, reports and analyses from recent field mapping programs, including the Iniskin Peninsula/Chinitna Bay area in Cook Inlet, and Umiat area on the North Slope.

- Provide new information on the liquid petroleum potential of Alaska's coal.

- Revive North Slope petroleum geology field work, with a focus on Brookian oil and gas reservoirs.

\section{Mineral Resources}

- Continue the release of new geologic information from recent mapping in high-mineral-potential areas of the state; publication of the Styx River and Wrangellia map areas are priorities.

- Publish summary reports on rare earth and platinum group occurrences.

- Begin making digital field-station mapping data available via the division's website.

- Publish results of geophysical surveys in the Porcupine River and Yukon River Bridge areas.

- Continue modernization and re-release of airborne geophysics data, and support the division's geophysical data acquisitions and releases.

\section{Public Safety and Community Resilience}

- Provide online, interactive statewide hazards maps for avalanche susceptibility.

- Provide additional coastal inundation and erosion data, map products, and online tools to coastal communities.

- Continue training residents in coastal communities to monitor shoreline change.

- Integrate the recently awarded NOAA Coastal Fellow into the coastal program.

- Continue to update shoreline position mapping of Alaska's north and west coast to allow erosion rate forecasting.

- Broaden relationships with university and federal organizations to enhance coastal and hazards capabilities.

- Make additional weather and coastal water-level data available in real-time. 
- Develop and expand working relationships with hazard mitigation and response organizations through successfully completing a landslide mapping project in Sitka and an erosion project in Emmonak.

- Continue to serve as administrators of the Alaska Seismic Hazard Safety Commission.

- Develop LiDAR collection capability to quickly, accurately, and effectively evaluate the geologic hazards which impact communities and infrastructure throughout the state.

\section{Data Delivery and Availability}

- Continue the transition to digital and interactive data delivery with new and upgraded interactive maps.

- Launch a redesigned website that provides users with easier access to the division's products and services.

\section{Geologic Materials Center}

- Integrate the new policy of charging for fees, data, and services provided by the facility into daily operations.
- Complete the process of vacating the old facility.

- Continue outreach and education programs at the new facility to help guide university, grade-school, middle school, and high school students.

- Improve curation of geologic materials by linking location and sample information for the $>50,000$ samples currently without location information.

\section{Volcanology}

- Publish the geologic map of Chiginagak Volcano.

- Provide new information on volcanic hazards impacts from Makushin volcano to Unalaska and Dutch Harbor.

- Create a framework of Alaska Peninsula ash fall hazards by analysis of lake core tephras in the region.

- Expand the Geologic Database on Volcanoes in Alaska (GeoDIVA) to hold tephra componentry and tephra petrographic descriptions.

- Complete hazard assessment for select Cook Inlet volcanoes as part of the update to the State Hazard Mitigation Plan.

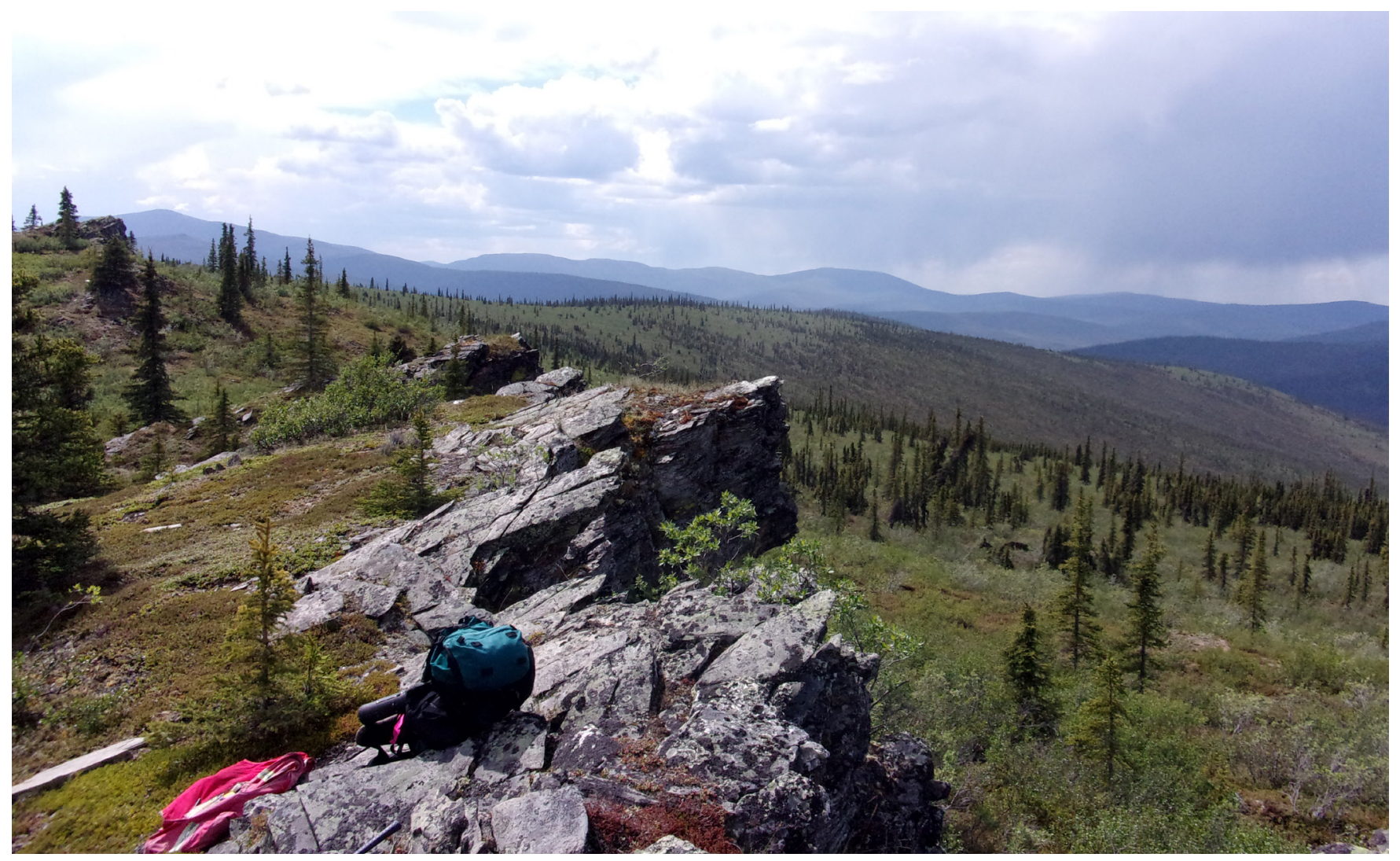




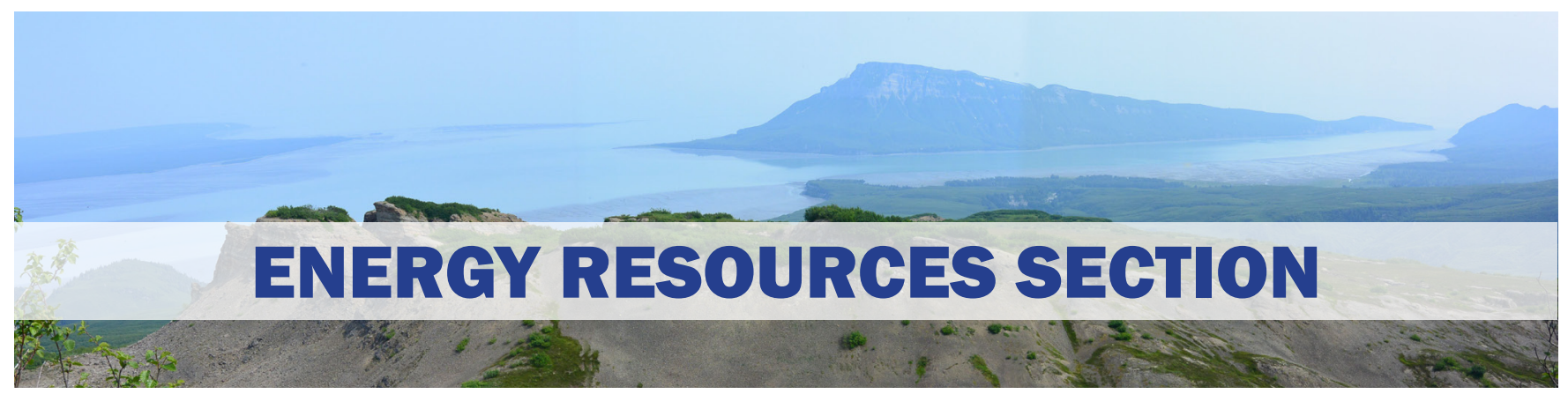

\section{BENEFIT TO ALASKA}

The Energy Resources Section generates new, unbiased information on the geologic framework of frontier areas in Alaska that may host undiscovered oil, gas, coal, and geothermal resources for improving the success of state-revenue-generating commercial oil and gas exploration and development, and improved understanding of potential local sources of energy for rural Alaska.

\section{MAJOR PROGRAMS AND PROJECTS}

- Cook Inlet basin analysis program

- Brooks Range foothills and North Slope program

- Natural gas potential of the Nenana basin

- Natural gas potential of the Susitna basin

- Liquid hydrocarbon potential of Alaskan coals

- Alaskan Coal Database - National Coal Resource Database System

\section{MAJOR ACCOMPLISHMENTS IN 2017}

Detailed Fault and Fracture Studies in Lower Cook Inlet Help Understand

\section{Deformation History}

DGGS geologist Bob Gillis co-authored two major reports about faulting and fracturing in Cook Inlet basin that were published in Geosphere, a high-profile scientific journal with an international readership. The papers address when, and under what conditions, a major fault that borders the basin, and related fractures that cut its stratigraphy, developed. Together, they contribute to a better understanding of the formation of structural hydrocarbon traps and fluid migration pathways in the basin. These pathways allow oil to

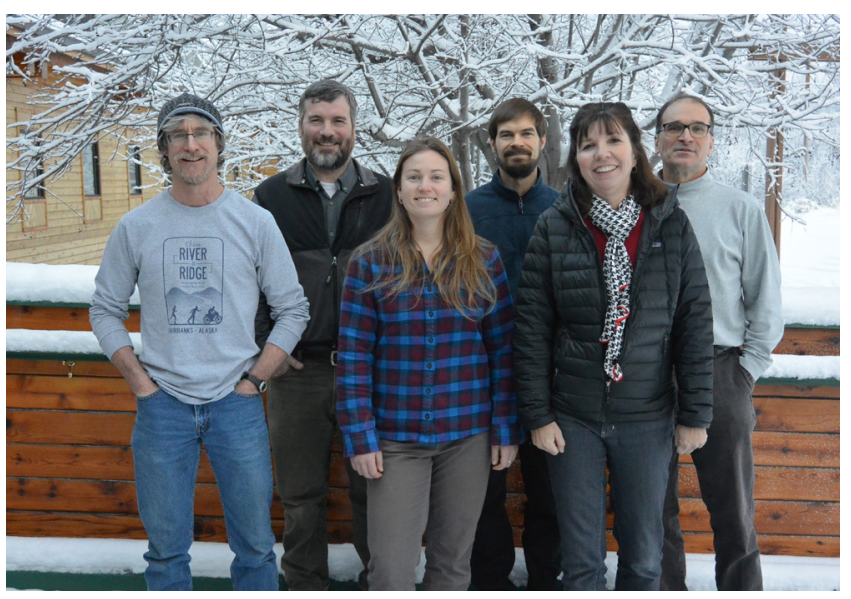

Bob Gillis, Marwan Wartes, Mandy Willingham, Trystan Herriott, Nina Harun, and Dave LePain

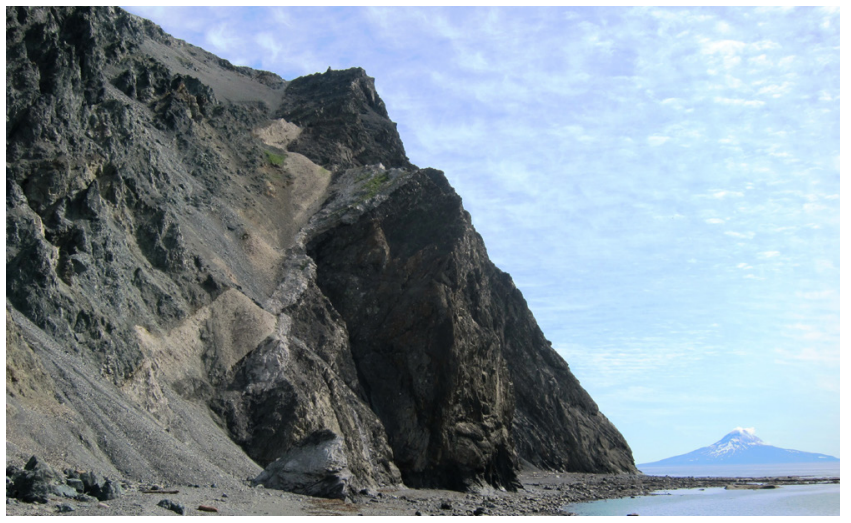

migrate from oil-prone source rocks to reservoirs, and a better understanding of their origin helps exploration geologists target areas for exploration. 


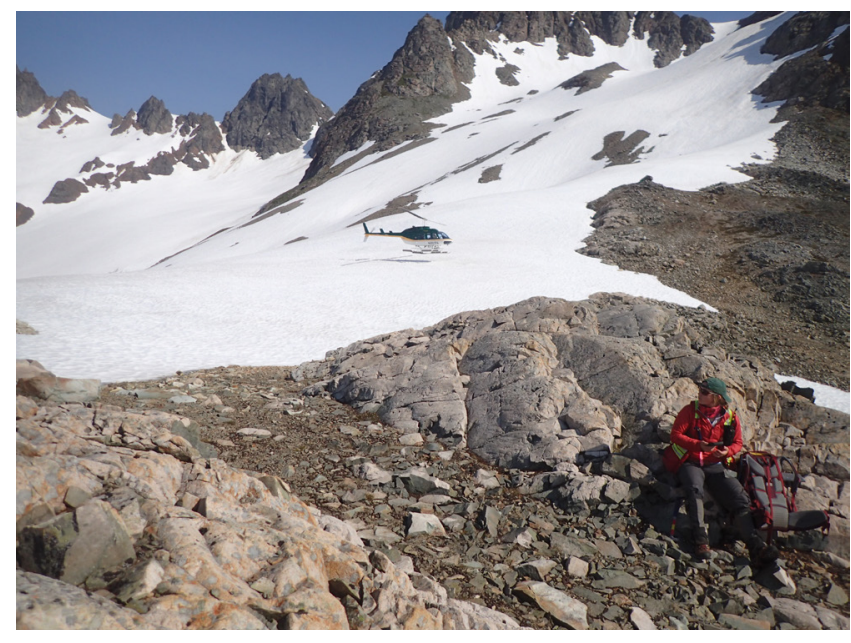

New Bedrock Geological Mapping in the Tuxedni Bay Area Provides New Details About Cook Inlet Basin Architecture

This past summer, approximately 176 square miles of new 1:63,360-scale bedrock geologic mapping was completed on the west side of lower Cook Inlet basin. The work completes a series of maps that encompass 700 square miles of the basin margin, containing the only known surface exposures of Middle Jurassic oil-prone source rocks. The subsurface equivalents of these rocks are thought to be the source for oil produced from fields in upper Cook Inlet. The recent mapping effort resulted in the discovery of a major outcrop of oil-stained sandstone (see below). The mapping provides new insights into how the basin developed and the reservoir potential of Mesozoic formations in lower Cook Inlet.

\section{Energy Database - Opening the Data Doors}

The energy section incorporated federal mapping database standards in its geologic database enabling easy data transfer and map production for all users. The positioning of Alaska energy data in a PostgreSQL database facilitates access to data and its application to better understanding Alaska's geology and energy resource potential. This effort expedites the flow and integration of energy data to DGGS users and, when fully developed, will allow the public easy access to data.

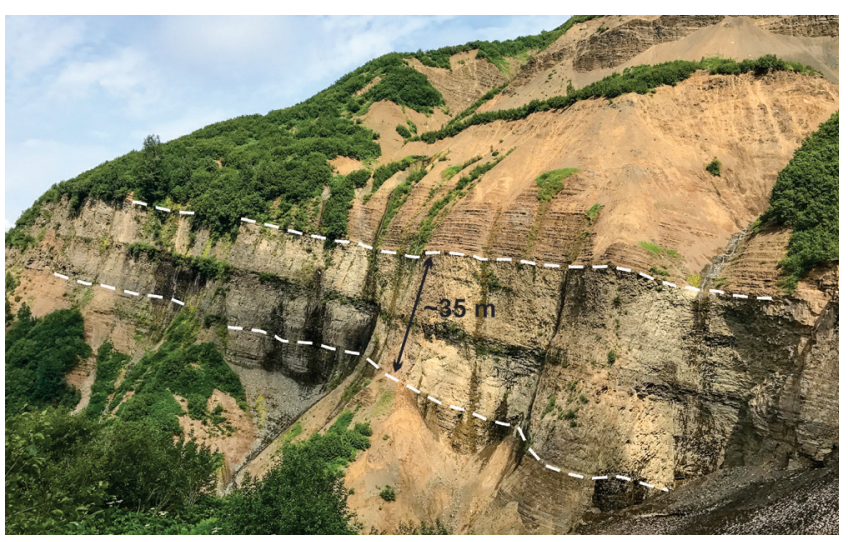

\section{Conventional Reservoirs in Cook} Inlet Mesozoic Strata? Discovery of Residual Oil in the Chinitna Formation Strengthens the Possibility

DGGS geologists discovered an oil-stained sandstone interval in the Middle Jurassic Chinitna Formation (Tonnie Siltstone Member) in lower Cook Inlet. An exposed 35-m-thick sandstone succession at the base of the Tonnie Siltstone appears to be oil stained throughout its thickness and lateral outcrop extent (greater than $250 \mathrm{~m}$ ). Sandstone blocks that have fallen from the vertical outcrop face are ubiquitously oil stained throughout their volume. This suggests that the oil is hosted in matrix porosity, which is remarkable since most known Jurassic sandstones in Cook Inlet basin are tight and the few petroleum occurrences they host are typically associated with fractures and faults. A relatively large volume of Jurassic-age rock such as this, with oil staining throughout its matrix volume, is significant and suggests the possibility that conventional oil reservoirs exist in strata of comparable age in the subsurface of Cook Inlet basin. Nearly all commercial oil production from Cook Inlet oil fields is from conventional reservoirs in younger Cenozoic rocks in structural traps. This discovery suggests that stratigraphic traps involving conventional reservoirs in Jurassic strata may represent a viable new petroleum play in the basin. Samples have been collected for reservoir quality analysis and petroleum geochemistry. A brief preliminary report summarizing this find was published. 


\section{Alaska Coal Database and the National Coal Resource Database System Highlight Liquid Hydrocarbon Potential}

Alaska's coal resources make up about half of the United States' coal resource base. Many of Alaska's coal fields now have modern analyses to characterize the coal quality parameters that are necessary to evaluate the suitability of coal for use in power generation. Less wellknown is the liquid hydrocarbon potential of Alaska's subsurface coal resources. Rock-Eval pyrolysis is an inexpensive, routine, rapid analysis that is widely used in the petroleum industry to assess a rock's hydrocarbon source potential. Rock-Eval pyrolysis is routinely done by several commercial laboratories in the United States. A project was initiated in 2016 to collect a suite of coal samples from selected Alaskan sedimentary basins for paired analysis of coal quality, Rock-Eval pyrolysis, and kerogen microscopy. In September 2017 a suite of coal samples was collected from several wells in the southeastern Susitna Basin and from Cook Inlet basin for Rock-Eval analysis. The resulting data will be entered into the U.S. Geological Survey's National Coal Resource Database System and DGGS' energy database. The samples are relevant to understanding the liquid hydrocarbon source potential of coal seams in the Susitna and Cook Inlet basins.

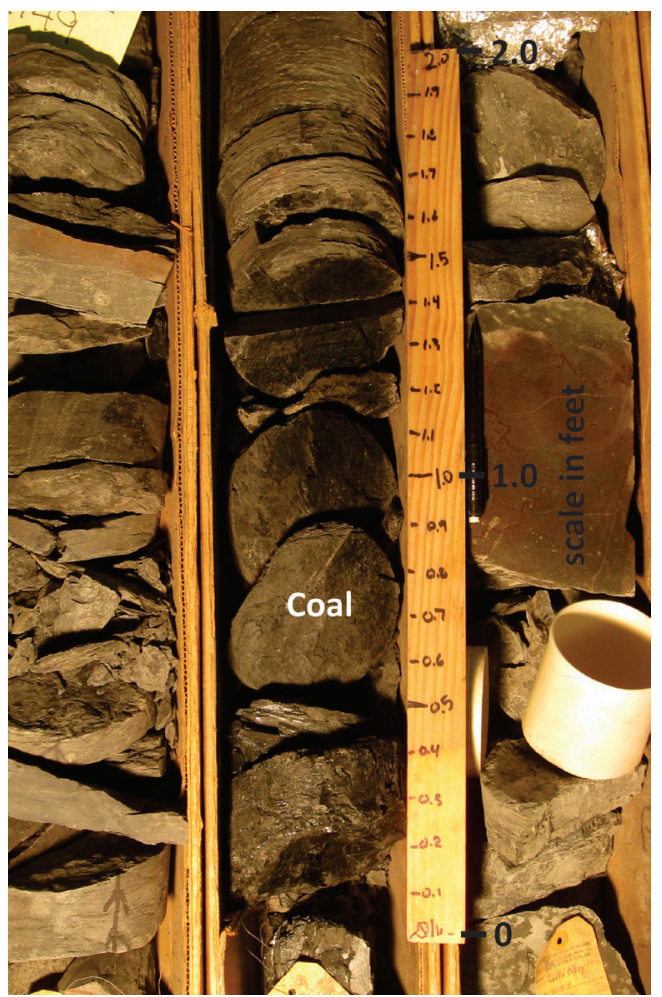

\section{NOTABLE ACHIEVEMENTS}

- Published two reports in a high-profile journal that address the basin-bounding Bruin Bay fault system and fractures in Mesozoic strata exposed along the west side of lower Cook Inlet

- Published a report addressing deep-water canyons and the sequence stratigraphic framework of the Upper Jurassic Naknek Formation in lower Cook Inlet basin, including implications for hydrocarbon reservoir potential.

- Published two reports on outcrops and shallow cores in the uplands surrounding Yukon Flats basin, including implications for reservoir potential in the subsurface of the basin.

- Delivered nine presentations on the petroleum geology of the North Slope and Cook Inlet basins to oil and gas geologists.

- Contributed two presentations on the structural development of the Susitna Basin and reservoir potential of its Cenozoic basin fill to the U.S. Geological Survey assessment team in preparation for an assessment of the undiscovered, but technically recoverable hydrocarbon resources in the Susitna basin.

- Co-chaired two presentation sessions at the 2017 Pacific Section of the American Association of Petroleum Geologists annual meeting held in Anchorage, Alaska, in May.

- Contributed to the implementation of the DGGS ArcGIS Server (enterprise geodatabase) using the Tyonek bedrock geological map dataset.

- Integrated energy data schema with DGGS division-wide database and NCGMP09 standards.

- Contributed 4,500 entries to the "Geologic Photos of Alaska" application and database, archiving photos from retired DGGS geologist Gil Mull.

- Hosted a well attended American Association of Petroleum Geologists, Pacific Section workshop, utilizing four GMC well core sets from the Nanushuk Formation.

- Led a three-day oil and gas field trip for industry geologists focusing on the geology of northern Alaska, including Torok and Nanushuk Formation outcrops. 


\section{ENERGY RESOURCES 2017 PUBLICATIONS}

Betka, P.M., Gillis, R.J., and Benowitz, J.A., 2017, Cenozoic sinistral transpression and polyphase slip within the Bruin Bay fault system, Iniskin-Tuxedni regiona, Cook Inlet, Alaska: Geosphere, v. 13, no. 6, http:// doi.org/10.1130/GES01464.1

Gillis, R.J., LePain, D.L., Herriott, T.M., Wartes, M.A., Decker, P.L., Shellenbaum, D.P., Benowitz, J.A., and O'Sullivan, P.B., 2017, Results of 1:63,360-scale geologic mapping and related field studies in the south-central Tyonek Quadrangle, Alaska: Late Paleocene?-middle Eocene transtension and post-Oligocene inversion on the northwest periphery of the Cook Inlet forearc basin: Pacific Section, AAPG, Anchorage, Alaska.

Gillis, R.J., Shellenbaum, D.P., Gregersen, L.S., and Fair, H.S., 2017, New insights in the Bruin Bay fault-Moquawkie structural trend, northwestern Cook Inlet basin, Alaska, from subsurface constraints and bedrock geologic mapping: Pacific Section, AAPG, Anchorage, Alaska.

Herriott, T.M., and Wartes, M.A., 2017, Discovery of a 35-meter-thick, oil-stained sandstone interval in outcrop of the Tonnie Siltstone Member, Chinitna Formation, lower Cook Inlet, south-central Alaska: Alaska Division of Geological \& Geophysical Surveys Preliminary Interpretive Report 2017-5, 12 p. http:// doi.org/10.14509/29837

Herriott, T.M., Wartes, M.A., and Decker, P.L., 2017, Deep-water canyons and sequence-stratigraphic framework of the Upper Jurassic Naknek Formation, Cook Inlet forearc basin, south-central Alaska: Alaska Division of Geological \& Geophysical Surveys Report of Investigation 2017-4, 53 p. http://doi. org/10.14509/29707

Herriott, T.M., Wartes, M.A., Stanley, R.G., Decker, P.L., Helmold, K.P., and Harun, N.T., 2017, Stratigraphy and sedimentology of the Chinitna Formation, Iniskin-Tuxedni bays area, south-central Alaska-Late Middle Jurassic depositional systems and petroleum prospectivity in Cook Inlet forearc basin (poster): Pacific Section, AAPG, Anchorage, Alaska.

LePain, D.L., Helmold, K.P., Gillis, R.J., Reger, R.D., and Swenson, R.F., 2017, Field trip guide: Sedimentology, reservoir quality, and tectonic setting of late Miocene-ear- ly Pliocene gas-bearing formations, upper Cook Inlet, Alaska.: Alaska Division of Geological \& Geophysical Surveys Miscellaneous Publication 161, 40 p.

LePain, D.L., Helmold, K.P., Wartes, M.A., and Decker, P.L., 2017, Depositional setting and potential reservoir facies in the Nanushuk Formation (Albian-Cenomanian), Brookian topset play, North Slope, Alaska: Pacific Section, AAPG, Anchorage, Alaska.

LePain, D.L., and Montayne, S., 2017, Core fragment descriptions, Exxon core holes, uplands bordering Yukon Flats basin, east-central Alaska: Alaska Division of Geological \& Geophysical Surveys Raw Data File 2016-4, 2 p., 1 sheet.

LePain, D.L., and Stanley, R.G., 2017, Reconnaissance sedimentology of selected Tertiary exposures in the upland region bordering the Yukon Flats basin, east-central Alaska: Alaska Division of Geological \& Geophysical Surveys Preliminary Interpretive Report 2016-6, 14 p.

Lillis, P.G., Lewan, M.D., Stanley, R.G., LePain, D.L., and Wartes, M.A., 2017, Are Tertiary coals from central and southern Alaska source rocks for oil?: Pacific Section, AAPG, Anchorage, Alaska.

Rosenthal, J.L., Betka, P.M., Nadin, Elisabeth, Gillis, R.J., and Benowitz, J.A., 2017, Vein formation during progressive Paleogene faulting and folding within the lower Cook Inlet basin, Alaska: Geosphere, v. 14, no. 1.

Wartes, M.A., 2017, New Insights into the Regional Stratigraphy of the Brookian Sequence in Northern Alaska: Case Studies on the Power of Merging Outcrop and Subsurface Data: Alaska Geology, Newsletter of the Alaska Geological Society, Geological Society, vol. 47, no. 5, p. 1-2.

Wartes, M.A., Decker, P.L., LePain, D.L., Gillis, R.J., and Herriott, T.M., 2017, Overview of Late Cretaceous depositional systems of the Colville foreland basin, east-central North Slope, Alaska: Pacific Section, AAPG, Anchorage, Alaska

Wartes, M.A., Stanley, R.G., Lillis, P.G., Helmold, K.P., Herriott, T.M., Decker, P.L., and Gillis, R.J., 2017, Preliminary observations on the stratigraphy, tectonics, and petroleum geology of Upper Cretaceous rocks in lower Cook Inlet, southern Alaska: Pacific Section, AAPG, Anchorage, Alaska. 


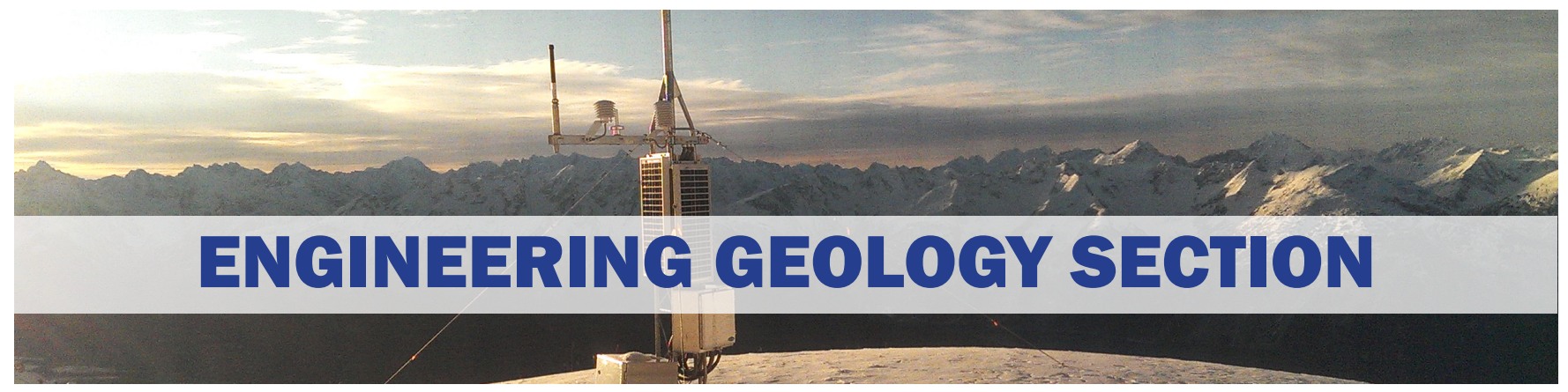

\section{BENEFIT TO ALASKA}

In many areas, Alaska lacks the fundamental geologic data needed to guide the proper development and implementation of building codes, land-use zoning, right-of-way siting, and contingency planning for natural hazards events. Maps and reports produced by the Engineering Geology Section are the front-line source of information about where damage is likely to be greatest and where mitigation efforts should be concentrated. Engineering-geologic maps depicting construction materials resources are useful for building infrastructure to support resource exploration and development, and for locating valuable placer-mineral deposits. Groundwater analysis and aquifer modeling and mapping in oil and gas basins and other areas of high development potential are essential to ensuring an adequate and safe supply of water for development and resource access.

\section{MAJOR PROGRAM ELEMENTS}

- Climate and Cryosphere

- Coastal Processes

- Construction Materials Resources

- Geohydrology

- Geologic Hazards

- Geologic Mapping

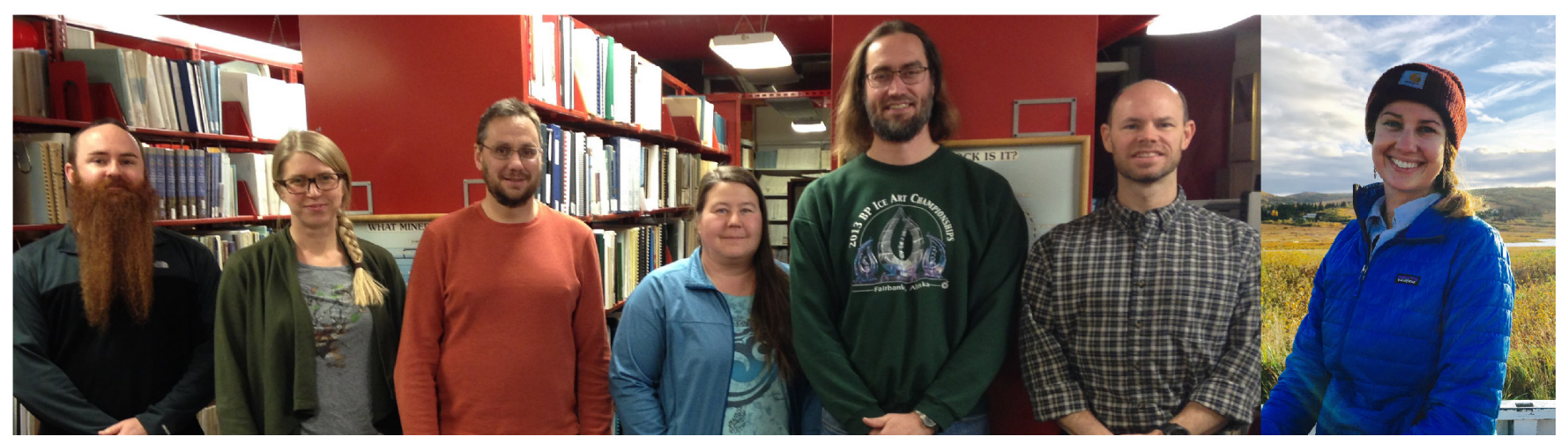

Above: Barrett Salisbury, Katreen Wikstrom Jones, Trent Hubbard, De Anne Stevens, Ronnie Daanen, Gabe Wolken, and Jacquelyn Overbeck 


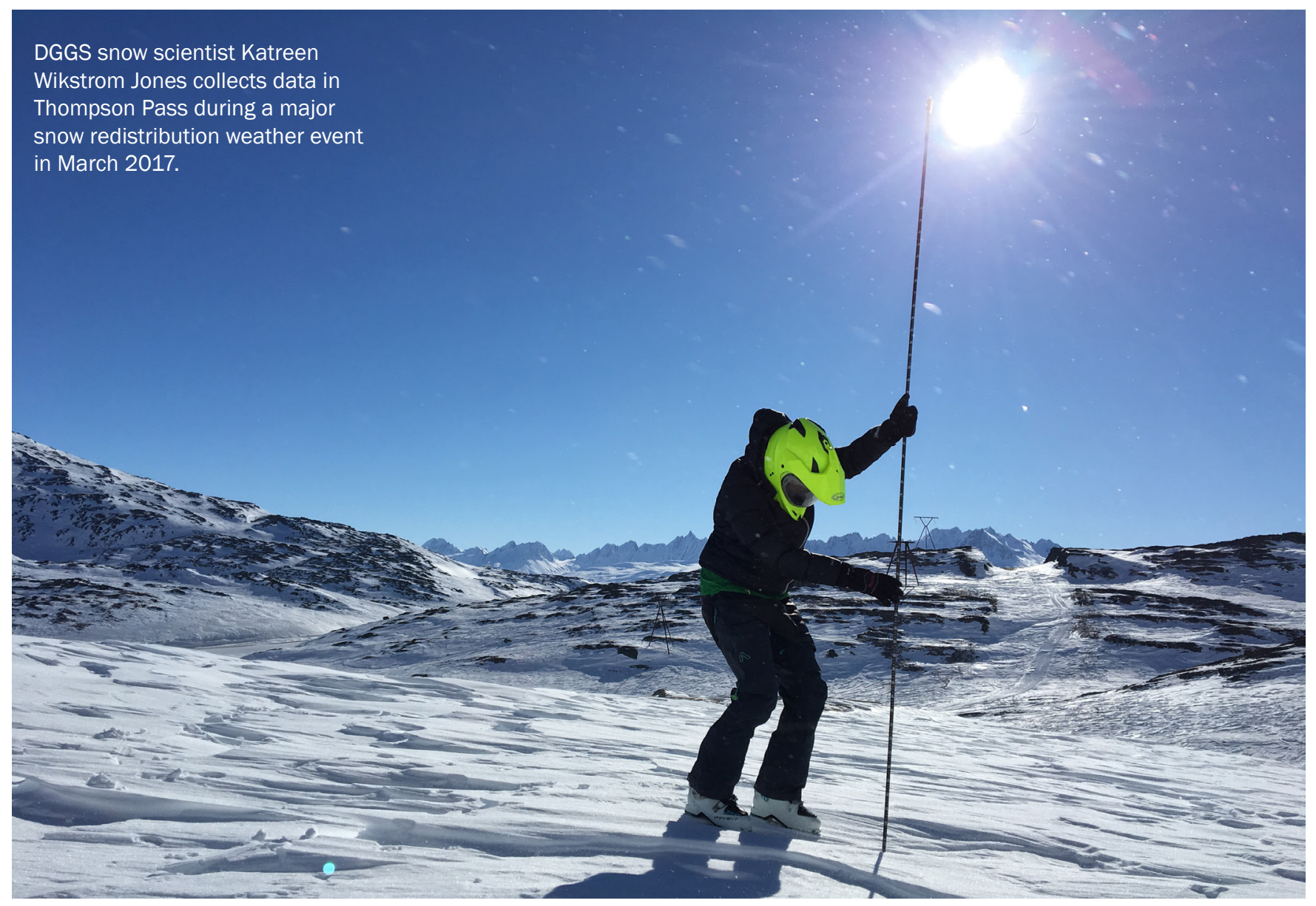

\section{THERE'S NO BUSINESS LIKE SNOW BUSINESS: CITIZEN SCIENTISTS HELP MEASURE ALASKA'S SNOWPACK}

Quantifying seasonal water retention and storage in mountain snowpacks is important for Alaska’s water resources, avalanche hazard mitigation, climate modeling, and economy. Runoff simulation models, which typically rely on climate data and remote sensing products, are greatly improved if uncertainties in snow depth distribution in high-elevation complex terrain are reduced. To this end, DGGS's Climate and Cryosphere Hazards Program (CCHP) is collaborating with the University of Alaska Fairbanks, University of Washington, and Oregon State University to conduct the Community Snow Observation (CSO, communitysnowobs.org) project in Alaska. This National Aeronautics and Space Administration (NASA)-funded project aims to improve and calibrate hydrologic models and remote sensing products used for estimating snow water equivalence and runoff by utilizing data collected by citizen scientists. The volunteer scientists use Mountain Hub, a crowdsourcing mobile app to help significantly increase the spatial and temporal coverage of snow observations in data-poor regions. The application allows users to record, submit, and instantly share geo-located snow depth, snow water equivalence measurements, measurement location photos, and snow grain information with anyone. The snow observations are being used to validate remote sensing products and improve snow distribution model results and avalanche hazard assessments. The project's prototype year, 2016-2017, focused on Thompson Pass in south-central Alaska, and we will plan to expand to other areas in Alaska in coming years. 

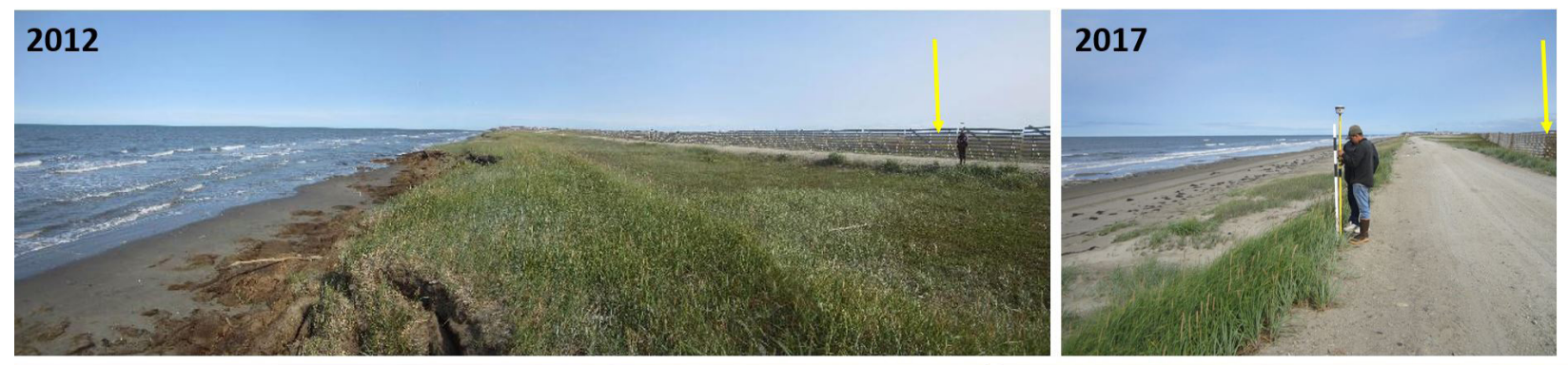

2012

2017
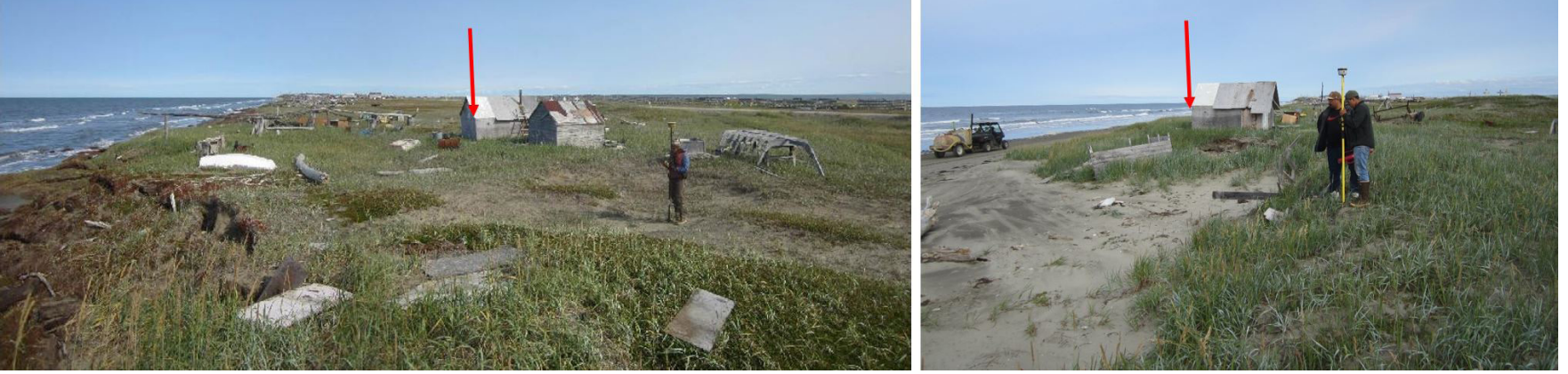

CH-CH-CH-CHANGES: WORKING WITH TRIBES TO COLLECT CRITICAL COASTAL CHANGE DATA FOR ALASKA

Flooding and erosion in Alaska have very localized impacts on infrastructure, land access, and community well-being. The DGGS Coastal Hazards Program is collaborating with the University of Alaska Fairbanks, Alaska Ocean Observing System, Alaska Sea Grant, Bristol Bay Native Association, the Bureau of Indian Affairs, Alaska Institute for Justice, National Weather Service, and many local tribal and city governments to establish erosion and flood monitoring sites throughout the state. DGGS visited 17 communities in the summer of 2017 to install sites and work with local governments, including at Port Heiden, Chignik Lagoon, Chignik Lake, Naknek, Kotlik, Chevak, Kwigillingok, Golovin, Shishmaref, Wales, Tununak, Dillingham, Aleknagik, Ekuk, Togiak, New Stuyahok, and Unalakleet. Ground surveys provide consistent baselines for future work as well as training for local individuals to conduct regular monitoring activities. Several site installations were completed in locations where DGGS staff have previously collected data; at these locations survey data will be added to the Alaska Coastal Profile Tool (maps.dggs.alaska.gov/acpt), where the public can view changes in cross-shore elevation profiles of local beaches between datasets collected over multiple
Above: Photos comparing cross-shore profiles at Shishmaref between an initial site visit by DGGS in 2012 (left) and a visit to install monitoring equipment in 2017 (right). Annie Weyiouanna and Corey Ningelook helped DGGS install erosion monitoring sites here in collaboration with the Alaska Institute for Justice.

years. Documenting changes to coastal and riverine shorelines increases our understanding of coastal systems, identifies storm surge impacts, justifies grant applications for mitigation resources, facilitates community planning for adapting to climate change, and contributes to statewide efforts to identify communities vulnerable to flooding and erosion.

\section{WELL DONE: NEW GROUNDWATER MONITORING WELLS FOR ALASKA}

In spring 2017 DGGS and University of Alaska, Fairbanks collaborators drilled two groundwater monitoring wells, "Blacksheep 2" and "Blacksheep 3," in Goldstream valley just north of Fairbanks. As part of the National Science Foundation (NSF) funded project "Methane release from thermokarst lakes: Thresholds and feedbacks in the lake to watershed hydrology-permafrost system," these wells are important for understanding permafrost interaction with groundwater. A major focus of the study attempts to quantify the loss of permafrost, as it has thawed from the bottom up since the last major ice age, and understand its contribution to methane 


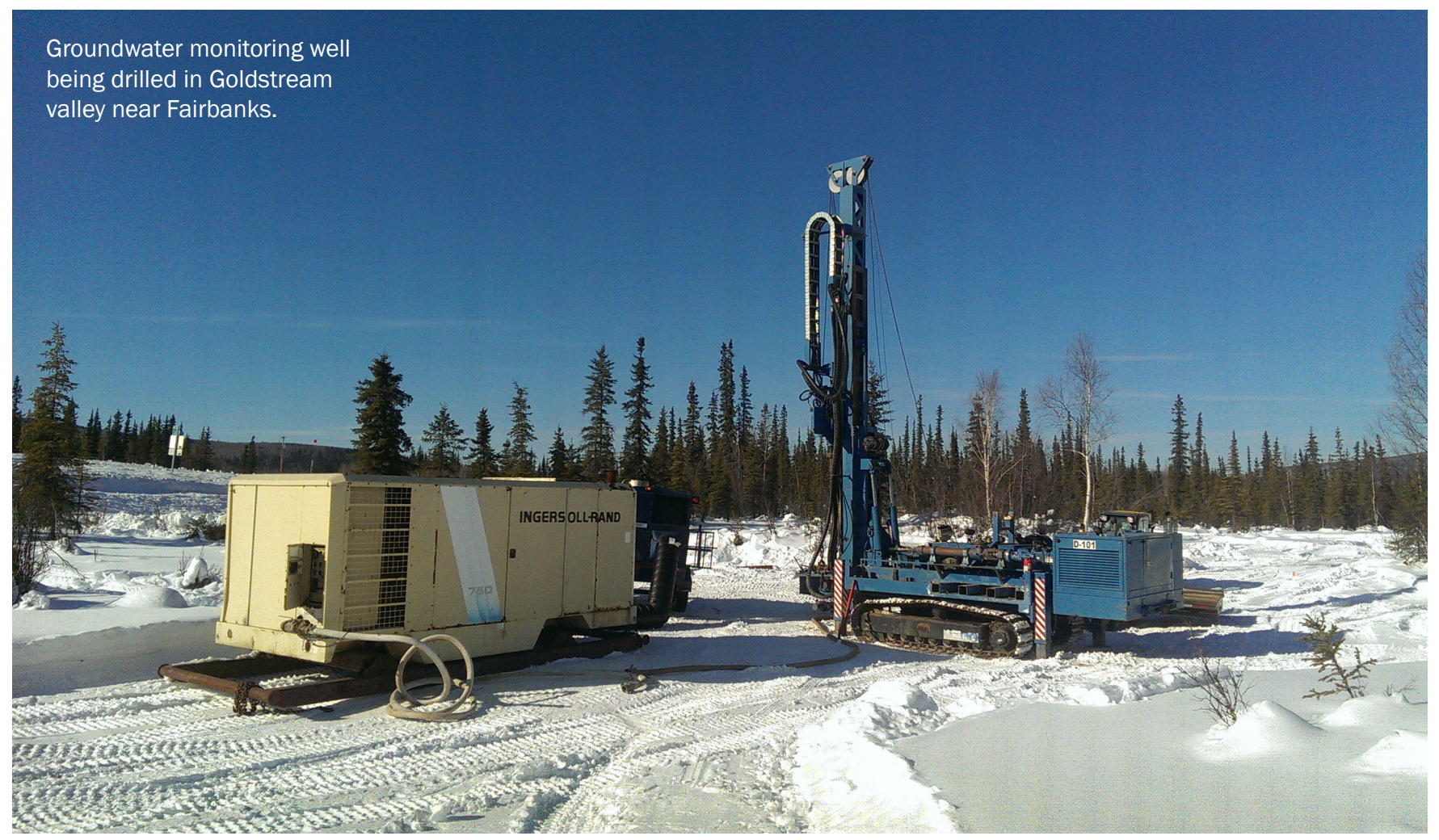

production, an important greenhouse gas that can be dissolved and transported by groundwater. The water level sensor in Blacksheep 2 is installed below permafrost and indicates the groundwater level is relatively constant and has a good connection with the deep water table in the region. Many residences use this aquifer as a source of drinking water.

In addition to helping understand groundwater and permafrost, data from the new wells will feed into the National Ground-Water Monitoring Network (cida.usgs.gov/ngwmn), a compilation of selected groundwater monitoring wells from Federal, State, and local groundwater monitoring networks across the nation. Groundwater hydrology is an interpretive science; because we cannot observe the resource directly, we must interpolate and extrapolate our understanding from known points of data. Waterlevel measurements from observation wells are the principal source of information about the hydrologic stresses acting on aquifers and how these stresses affect groundwater recharge, storage, and discharge. These two wells have doubled the number of Alaska wells reporting to the network.
TO MINE OR NOT TO MINE: A QUESTION OF SLOPE INSTABILITY AND THE TRANS-ALASKA PIPELINE

The State Pipeline Coordinator and the Department of Natural Resources' Division of Mining, Land and Water requested that DGGS evaluate a hillside adjacent to the Trans-Alaska Pipeline System (TAPS) near Treasure Creek, north of Fairbanks, because of the possibility that mining activities may resume in the area. The slope has been monitored on behalf of Alyeska Pipeline Service Company for many years and investigations indicate that downslope movement is problematic and soil creep an ongoing issue. One possible concern was that potential, future mining activity in this area could destabilize the slope and impact TAPS. DGGS was tasked with assessing likely outcomes through the evaluation of geophysical data, LiDAR elevation data, existing borehole data, and field reconnaissance. A geologic evaluation of this slope was critical and provided timely, quality, scientific information to help make important land management decisions. 
DGGS geologists and staff

from the Division of Mining, Land and Water conduct field work to evaluate potential slope instability impacts to the Trans-Alaska Pipeline right-of-way near Treasure Creek.

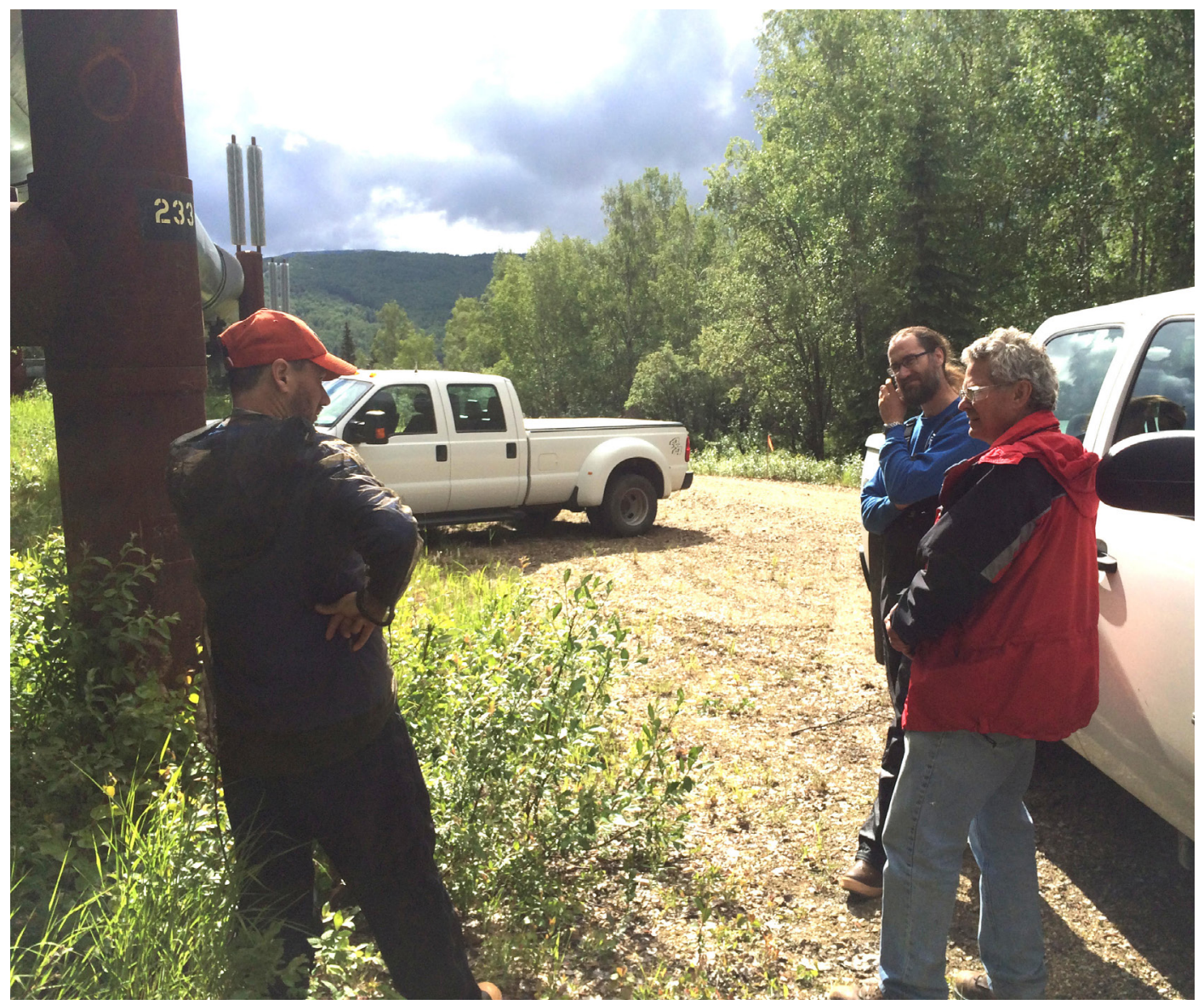

Satellite and airborne imagery and field observations indicate historic and ongoing slow creep on the slope near Treasure Creek, but analysis of multiple epochs of LiDAR do not show significant or recent, rapid downslope movement of material. Geophysical data, coupled with subsurface data from borehole logs, allowed us to evaluate the condition of permafrost and its distribution on the slope. The middle portion of the slope is currently undergoing permafrost degradation and collapse while the lower portion of the slope is underlain by a thick zone of currently stable, ice-rich permafrost. We recommended land use restrictions to minimize activities that would result in significant disturbance of vegetation on the slope directly below TAPS to avoid further destabilization of ice-rich permafrost. Minor disturbances from recreational activities, such as trail use, are not likely to negatively impact the slope, however, mining and vegetation clearing should be avoided in a buffer zone around and downslope of the pipeline.

\section{MAKING WAVES: COMMUNICATING TSUNAMI HAZARDS TO AT-RISK COMMUNITIES IN COASTAL ALASKA}

Historically, tsunamis generated by earthquakes in Alaska have caused major damage and loss of life all along the West Coast and across the Pacific, but coastal Alaska has the most serious tsunami risk in the United States. While all Alaskans live with earthquake hazards, those in many coastal communities may have only minutes to reach safety from earthquake- and landslide-generated tsunami waves. DGGS works closely with researchers from the Alaska Earthquake Center (AEC) at the University of Alaska, Fairbanks who numerically model plausible tsunami inundation scenarios and generate maps and hazard reports for at-risk communities in coastal Alaska (maps.dggs.alaska.gov/tsunami). In collaboration with the Division of Homeland Security and Emergency Management and NOAA's National Tsunami 
Warning Center, scientists from DGGS and AEC work together to share tsunami science expertise and communicate tsunami hazards to at-risk communities in Alaska. Funding for this project is provided by the National Oceanic and Atmospheric Administration under the National Tsunami Hazard Mitigation Program.

In 2017 we, along with AEC staff, published tsunami hazard maps for King Cove, Cold Bay, Nikolski, Chignik, Chignik Lagoon, Sand Point, Juneau, Unalaska, and Akutan. The Juneau study is the first of its kind for the capital city and shows that an underwater landslide in Fritz Cove may present a potential tsunami hazard for Juneau that is greater than what is predicted for an earthquake-generated tsunami. Used by community members, scientists, engineers, community planners, and emergency response personnel to develop action plans for when a tsunami threatens, these maps and reports are an important means of communicating and mitigating tsunami risks to help prevent damage to property and loss of life.

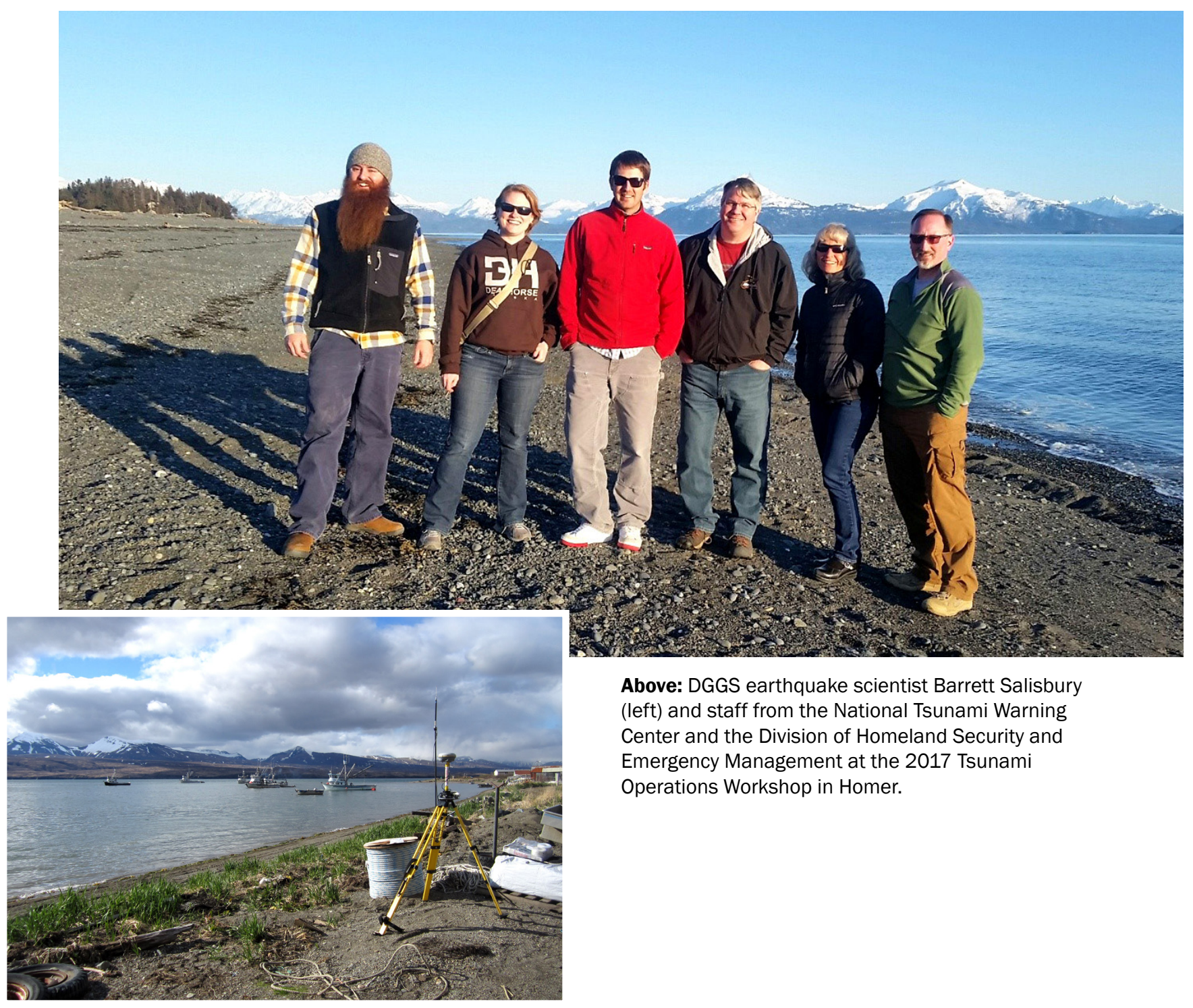




\section{NOTABLE ACHIEVEMENTS}

- Expanded and updated our color-indexed elevation map series for 11 coastal communities. Color-indexed maps facilitate communication between local city and/or tribal officials and the National Weather Service when a storm surge is forecasted in the Bering Sea.

- Installed real-time hazards monitoring equipment for debris flows and glacier lake outburst floods at Valdez, Haines, and Kenai Fjords National Park where these natural hazards threaten public safety and infrastructure.

- Successfully recruited and hired a senior-level earthquake geologist to manage the DGGS Earthquake Geology Program, research earthquake and tsunami hazards across the state, and communicate these hazards to stakeholders.

- Collected 3,000 line-kilometers of airborne electromagnetic and magnetic geophysical data in and near Goldstream Valley, Fairbanks, and at the Dalton Highway crossing of the Yukon River to help understand subsurface geology, permafrost distribution, and hydrology in support of infrastructure planning, development, and maintenance. These surveys were funded by the National Science Foundation (NSF) and the Alaska Department of Transportation \& Public Facilities (ADOT\&PF).

- Completed a collaborative NSF-funded project with the University of Alaska Fairbanks investigating shrub expansion along small creeks in the Arctic that has implications for winter water discharge and increased likelihood of aufeis formation downstream of these groundwater flows. This research is important for understanding potential climate change impacts to infrastructure development and maintenance in northern Alaska.

- In collaboration with the University of Alaska Fairbanks, we were awarded a major new NSF grant to study ice wedge degradation and recovery on the Arctic Coastal Plain. This research is important for understanding potential climate change impacts to infrastructure development and maintenance in northern Alaska.

- Continued participation in a joint project with the University of Alaska Fairbanks to study and monitor slow-moving frozen landslides, known as "frozen debris lobes," along the Dalton Highway. Our measurements indicate that one of these landslides will override the highway in about six years, and planning is underway by ADOT\&PF to move the road.

- Continued work on a FEMA-funded project to map landslide hazards in Sitka. We are also involved in a related side project funded by the City of Sitka and the Sitka Sound Science Center that aims to develop a landslide early warning system for the community.

- Published a Digital Surface Model (DSM) and orthoimage of major debris flow channels along the Haines Highway, the first dataset of six to be published covering the fall and spring periods of 2014-2016. At the request of ADOT\&PF, we will use these data to analysis sediment transport that is impacting the highway and making it the most expensive segment of road to maintain in the state.

- Built and released DGGS's first ArcGIS story map, about glacial lake outburst floods in Alaska and our hazard monitoring program. This story map is a novel education-outreach tool to inform the public about this significant geologic hazard.
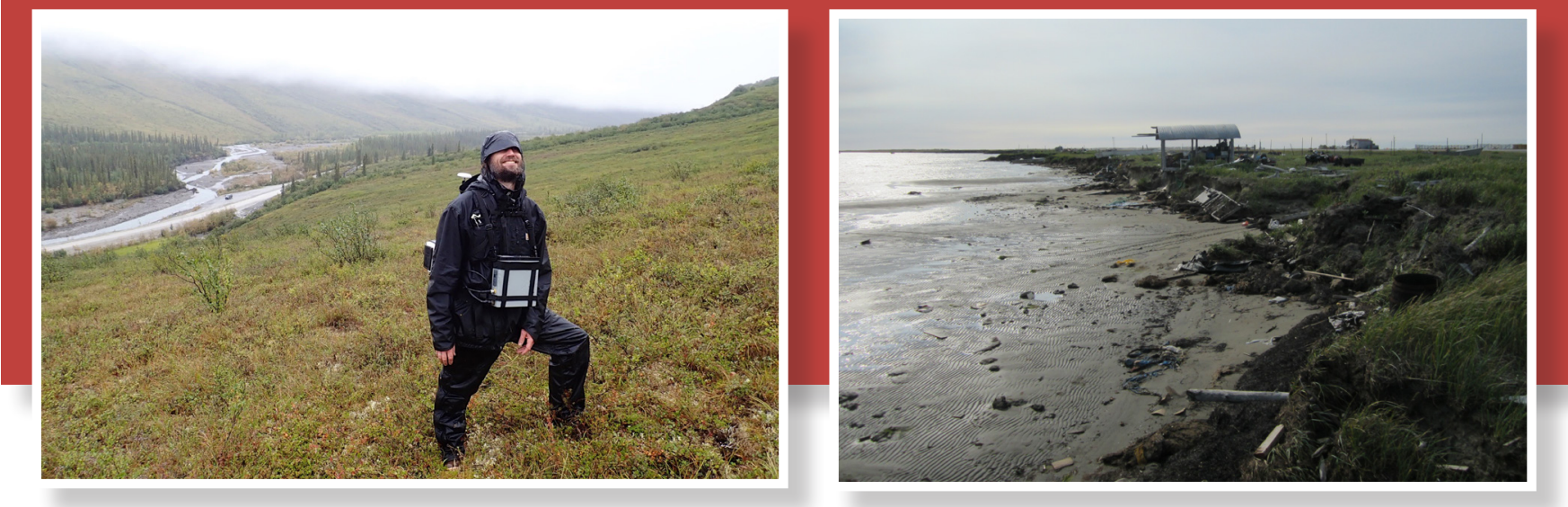


\section{ENGINEERING GEOLOGY 2017 PUBLICATIONS}

Combellick, R.A., and Reger, R.D., 2017, Field trip guide: The 1964 Great Alaska Earthquake and its predecessors in the Anchorage and Turnagain Arm areas: Alaska Division of Geological \& Geophysical Surveys Miscellaneous Publication 162, 28 p. http://doi.org/10.14509/29714

DeRaps, M.R., Kinsman, N.E.M., Stevens, D.S.P., and Overbeck, J.R., 2017, Surficial geologic map of the Shaktoolik area, Norton Bay Quadrangle, Alaska: Alaska Division of Geological \& Geophysical Surveys Report of Investigation 2017-5, 1 sheet, scale 1:50,000. http://doi. org/10.14509/29723

Hubbard, T.D., 2017, Slope instability drilling program, Tonsina Hill, Alaska: Alaska Division of Geological \& Geophysical Surveys Preliminary Interpretive Report 2017-1, 36 p. http://doi.org/10.14509/29710

Nicolsky, D.J., Suleimani, E.N., and Koehler, R.D., 2017, Potential maximum permanent flooding maps for Chenega, Alaska, in Nicolsky, D.J., Suleimani, E.N., and Koehler, R.D., Tsunami inundation maps of the villages of Chenega Bay and northern Sawmill Bay, Alaska: Alaska Division of Geological \& Geophysical Surveys Report of Investigation 2014-3A, 1 sheet, scale 1:3,500. http://doi. org/10.14509/29751

-Potential maximum permanent flooding maps for the communities of Chignik and Chignik Lagoon, Alaska, in Nicolsky, D.J., Suleimani, E.N., and Koehler, R.D., Tsunami inundation maps for the communities of Chignik and Chignik Lagoon, Alaska: Alaska Division of Geological \& Geophysical Surveys Report of Investigation 2016-8A, 2 sheets. http://doi.org/10.14509/29753

-Tsunami inundation maps for the city of Sand Point, Alaska: Alaska Division of Geological \& Geophysical Surveys Report of Investigation 2017-3, 61 p., 4 sheets, scale 1:15,000. http://doi.org/10.14509/29706

Nicolsky, D.J., Suleimani, E.N., Koehler, R.D., and Salisbury, J.B., 2017, Tsunami inundation maps for Juneau, Alaska: Alaska Division of Geological \& Geophysical Surveys Report of Investigation 2017-9, 66 p., 5 sheets. http://doi. org/10.14509/29741

Nicolsky, D.J., Suleimani, E.N., Freymueller, J.T., and Koehler, R.D., 2017, Potential maximum permanent flooding maps for Unalaska and Akutan, Alaska, in Nicolsky, D.J., Suleimani, E.N., Freymueller, J.T., and Koehler, R.D., Tsunami inundation maps of Fox Islands communities, including Dutch Harbor and Akutan, Alaska: Alaska Division of Geological \& Geophysical Surveys Report of Investigation 2015-5A, 2 sheets. http://doi. org/10.14509/29728

Overbeck, J.R., 2017, Storm water level feature extraction from digital elevation models using intra-storm photo- graphs: Alaska Division of Geological \& Geophysical Surveys Report of Investigation 2017-6, 10 p. http://doi. org/10.14509/29730

Overbeck, J.R., Kennedy, Katrina, and Heim, Rebecca, 2017, Color-indexed elevation maps for flood-vulnerable coastal communities in western Alaska: Alaska Division of Geological \& Geophysical Surveys Miscellaneous Publication 154 v.2, 23 p., 36 sheets. http://doi.org/10.14509/29719

Overbeck, J.R., Hendricks, M.D., and Kinsman, N.E.M., 2017, Photogrammetric digital surface models and orthoimagery for the continuous coastline, Wales to Platinum, Alaska: Alaska Division of Geological \& Geophysical Surveys Raw Data File 2017-8, 21 p. http://doi. org/10.14509/29744

-Photogrammetric digital surface models and orthoimagery for the continuous coastline, Wales to Platinum, Alaska, segment A: Wales to Teller: Alaska Division of Geological \& Geophysical Surveys Raw Data File 20178A, 4 p. http://doi.org/10.14509/29771

Photogrammetric digital surface models and orthoimagery for the continuous coastline, Wales to Platinum, Alaska, segment B: Teller to Nome, in Overbeck, J.R., Hendricks, M.D., and Kinsman, N.E.M., Photogrammetric digital surface models and orthoimagery for the continuous coastline, Wales to Platinum, Alaska: Alaska Division of Geological \& Geophysical Surveys Raw Data File 2017-8B, 4 p. http://doi.org/10.14509/29745

Photogrammetric digital surface models and orthoimagery for the continuous coastline, Wales to Platinum, Alaska, segment C: Nome to Elim, in Overbeck, J.R., Hendricks, M.D., and Kinsman, N.E.M., Photogrammetric digital surface models and orthoimagery for the continuous coastline, Wales to Platinum, Alaska: Alaska Division of Geological \& Geophysical Surveys Raw Data File 2017-8C, 3 p. http://doi.org/10.14509/29772

Suleimani, E.N., Nicolsky, D.J., and Koehler, R.D., 2017, Updated tsunami inundation maps of the Kodiak area, Alaska: Alaska Division of Geological \& Geophysical Surveys Report of Investigation 2017-8, 38 p., 10 sheets. http://doi.org/10.14509/29740

Stewart, A.K., Heinrich, C.E., and Hubbard, T.D., 2017, Dendrogeomorphic evidence of frequent mass movement using reaction wood in black spruce: Alaska Highway milepost 1267, Northway Junction, Alaska: Alaska Division of Geological \& Geophysical Surveys Report of Investigation 2017-7, 18 p. http://doi.org/10.14509/29734

Wolken, G.J., Wikstrom Jones, Katreen, Whorton, E.N., Gould, A.I., and Hendricks, M.D., 2017, Photogrammetric data of the Haines Highway corridor: May 26, 2014: Alaska Division of Geological \& Geophysical Surveys Raw Data File 2017-6, 20 p. http://doi.org/10.14509/29736 


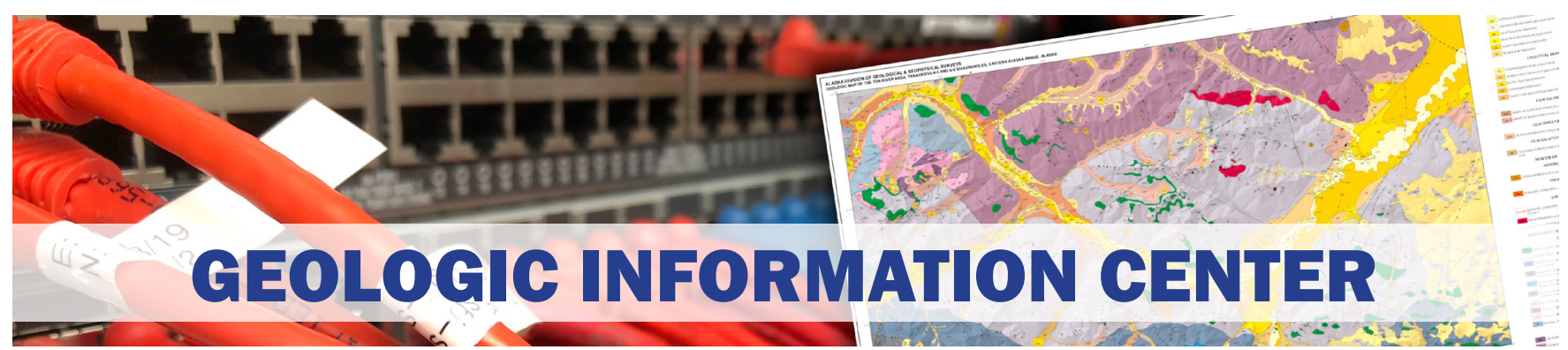

Creates, preserves, and distributes publicly available geologic maps, reports, and data to improve the knowledge of Alaska's natural resources and geologic hazards.

\section{BENEFIT TO ALASKA}

Information availability creates value: Geologic information about Alaska's resources promotes informed land-management decisions and encourage investment, exploration, and development of the state's resources, resulting in billions of dollars of impact to Alaska's economy.

Protects lives and reduces property damage: Availability of information specific to the state's volcanoes, earthquakes, landslides, tsunamis, coastal erosion, and climate change helps mitigate these natural hazards, save lives, and reduces damage to property and critical infrastructure.

\section{GIC OBJECTIVES}

- Create online geospatial applications for efficient delivery of geologic data

- Continuously develop and maintain Alaska's geologic data repository

- Publish geologic information (maps, reports, digital data)

- Maintain and develop the division's computing resources

- Account for and maintain critical field safety and communication equipment
Tom Cerny, Sue Seitz, Trish Gallagher, Kristen Hendricks, Mike Hendricks, Ken Papp, Simone Montayne (front), not pictured: Kenny Woods

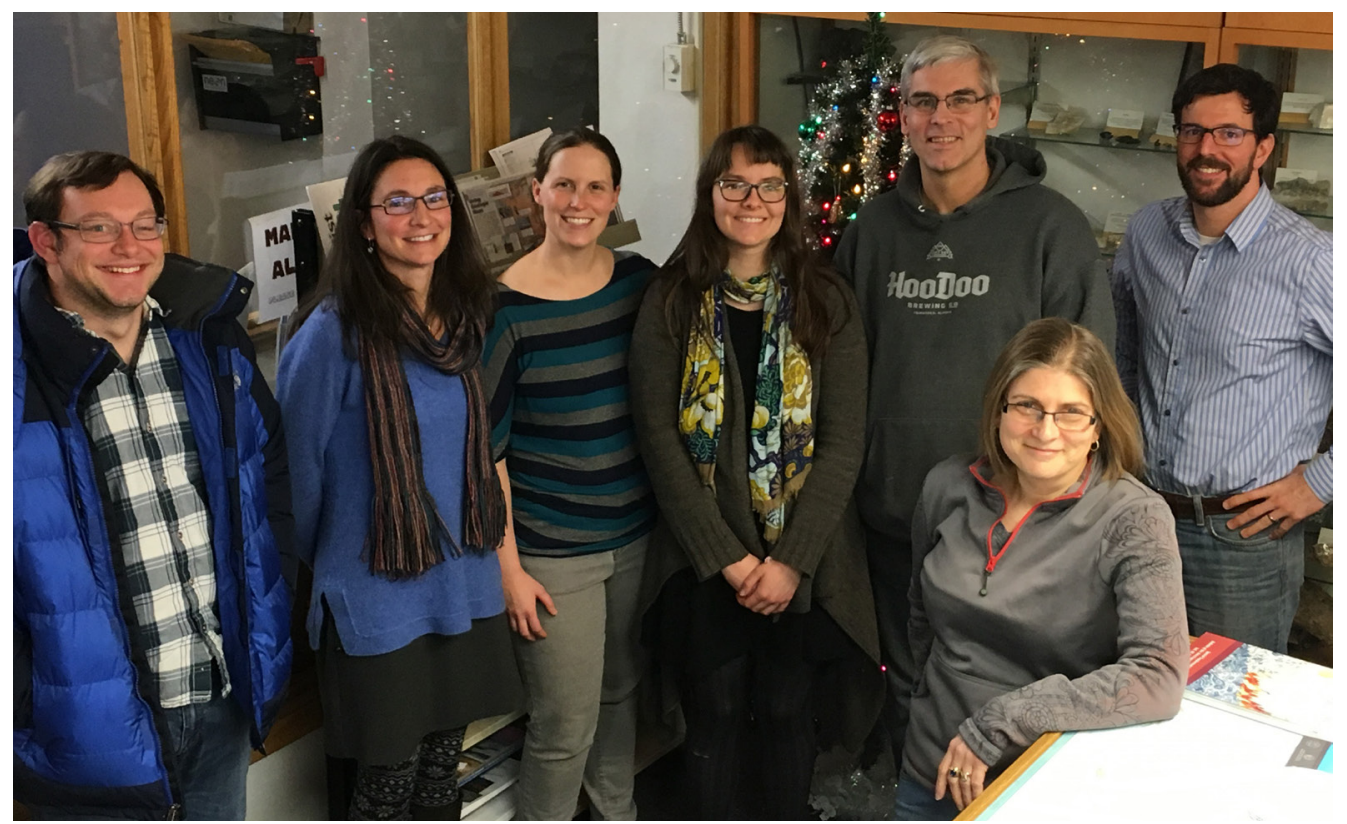




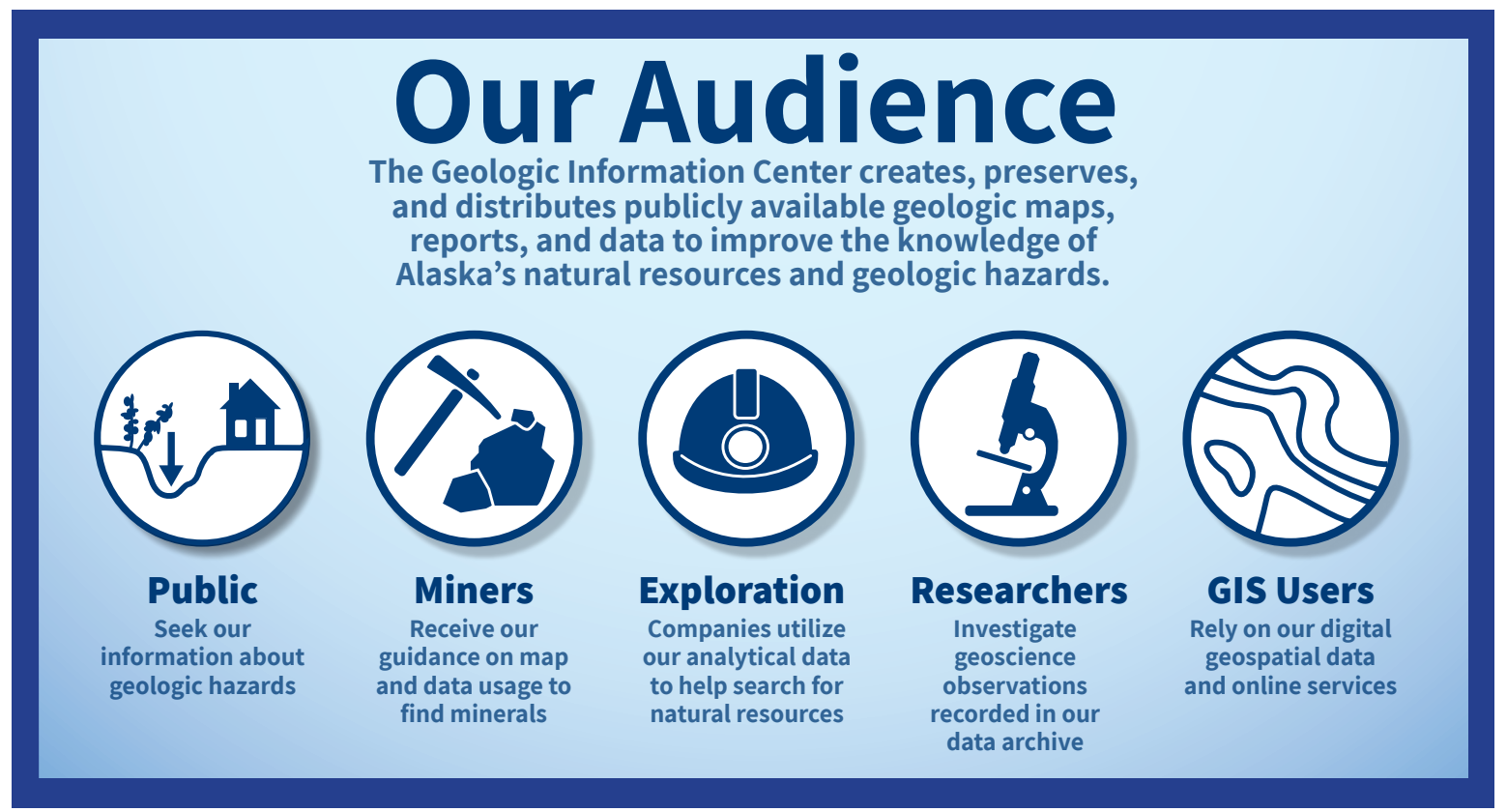

\section{FOCUS ON THE ROCKS: GEOLOGIC PHOTOS OF ALASKA NOW AVAILABLE ONLINE}

DGGS released more than 6,500 free public-use photographs taken during geologic field projects via an interactive application on its website (maps.dggs.alaska.gov/photodb). The photographs document scenery, landforms, rock outcrops, geologic observations, vegetation, wildlife, and fieldwork activities conducted throughout Alaska, usually in remote locations that are often impossible or prohibitively expensive to revisit. Many of the photographs currently available were taken by former DGGS geologists Charles G. (Gil) Mull and Rocky R. Reifenstuhl from 1970 through 2010 in the Brooks Range and northern Alaska during energy-resources-related geologic mapping projects. Additional photographs, from legacy collections and other geologic projects in Alaska, will become available through the application as time and funding allow.
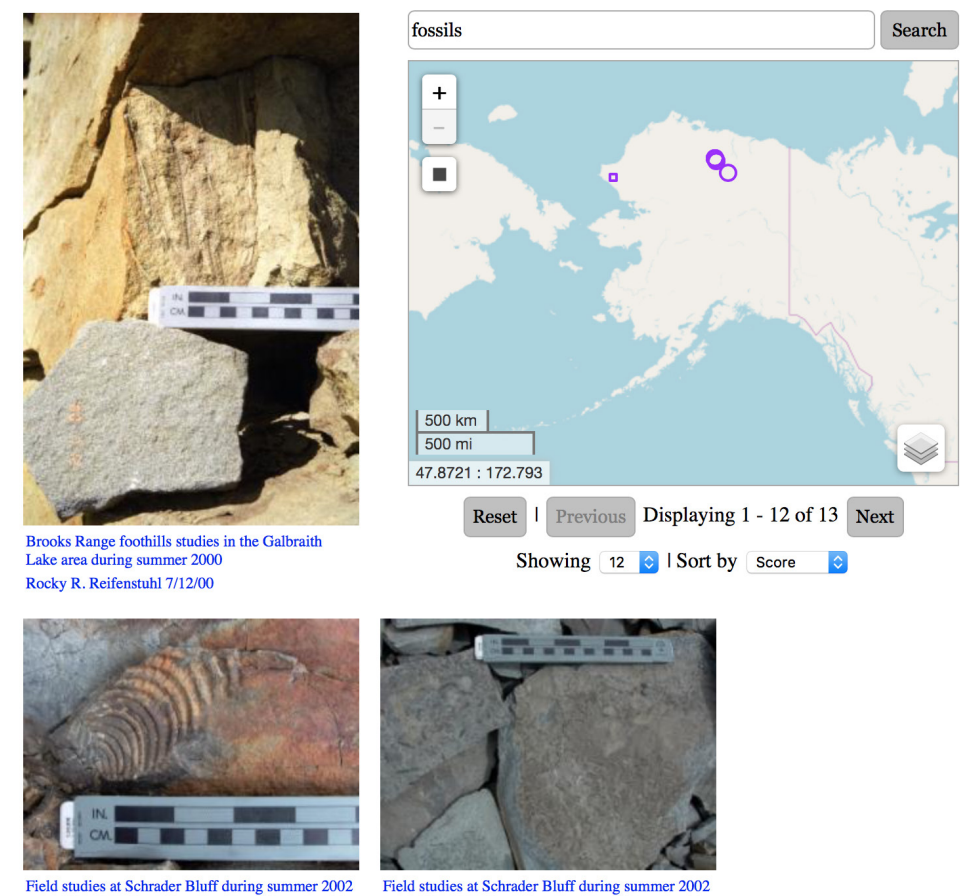

Rocky R. Reifenstuhl 7/6/02

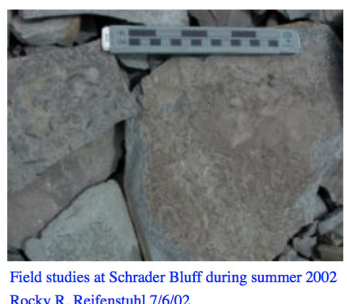

Rocky R. Reifenstuhl $7 / 6 / 02$

The map on the web page shows where the photograph was taken and any contextual information known about the photograph is recorded and searchable. Because photographs capture a moment in time, the format allows information about ephemeral features such as stream locations, unstable outcrops, landslides, and other transient ground conditions to be easily captured with significant future usability. It is virtually impossible to identify in advance which photographs will be the most valuable over time. For example, landscape photographs taken since the late 1800s are now successfully being used to estimate glacier retreat. Beyond their scientific use, many of the photographs intrinsically document the natural beauty and history of Alaska, which carries an enormous value for tourists, journalists, digital media designers, teachers, and historians. More information about the Geologic Photos of Alaska application is available at dggs.alaska.gov/pubs/id/29735. 


\section{GOT ZINC? IMPROVED ONLINE SEARCH TOOL FOR ALASKA ROCK SAMPLES}

Obtaining the analyses of rock samples with high levels of zinc, gold, and copper just got a whole lot easier. Rock geochemistry is essential to the understanding and development of Alaska's lands. This information is used by mineral exploration companies to generate new prospects and target high-grade zones, by geologists to "fingerprint" and map rock packages, and by environmental researchers to locate and mitigate the risk of naturally occurring or introduced hazardous materials.

DGGS’ Geologic Information Center (GIC) has released a complete redesign of its geochemistry web application available at maps.dggs.alaska.gov/geochem. The new version allows users to search the database by drawing a box on an interactive map or typing in a Google-like search box. The results include analytical methods, sample types, and specific chemical elements for more than 70,000 samples from all over the state. The database will be continually updated as new DGGS geochemical analyses are released.

With this major application upgrade, users can now download the geochemical data in two different formats; one optimized for GIS software and the other for analytical and database software. A linked help file contains useful examples on how to use the lightning-quick search bar to narrow your queries on geochemical analyses. More information about the Alaska Geochemistry online application is available at dggs.alaska.gov/pubs/id/29770.

\section{WHERE'S THAT SAMPLE?}

The GIC and Geologic Materials Center (GMC) are capturing locations for 40,000 undocumented DGGS surface samples stored at the GMC, as part of the National Geological and Geophysical Data Preservation Program (NGGDPP). This project will significantly advance the data infrastructure needed to achieve the long-term goal of an integrated sample management system that promotes public discovery of DGGS's geologic samples.

With the dust settled from transferring nearly 3 million pounds of geologic materials to their new Anchorage based facility and the development of a new database management system in 2016, the GMC has assessed the remaining needs of their collections. The DGGS outcrop sample collection stands out as the most underutilized collection, largely because many of the samples lack specific locations. The partially inventoried collection contains more than 65 years' worth of undocumented surface samples collected by DGGS geologists from many Alaska projects—a significant untapped resource of geologic information.

Readily accessible databases and a recent effort to standardize sample data provided a perfect window of opportunity to obtain funding from the U.S. Geological Survey's NGGDPP and make progress towards reaching this goal. The DGGS enterprise database is currently estimated to contain field station and/or sample metadata needed for 27,000 of the 70,000 undocumented GMC samples. The common field "Field Station Number" was recently

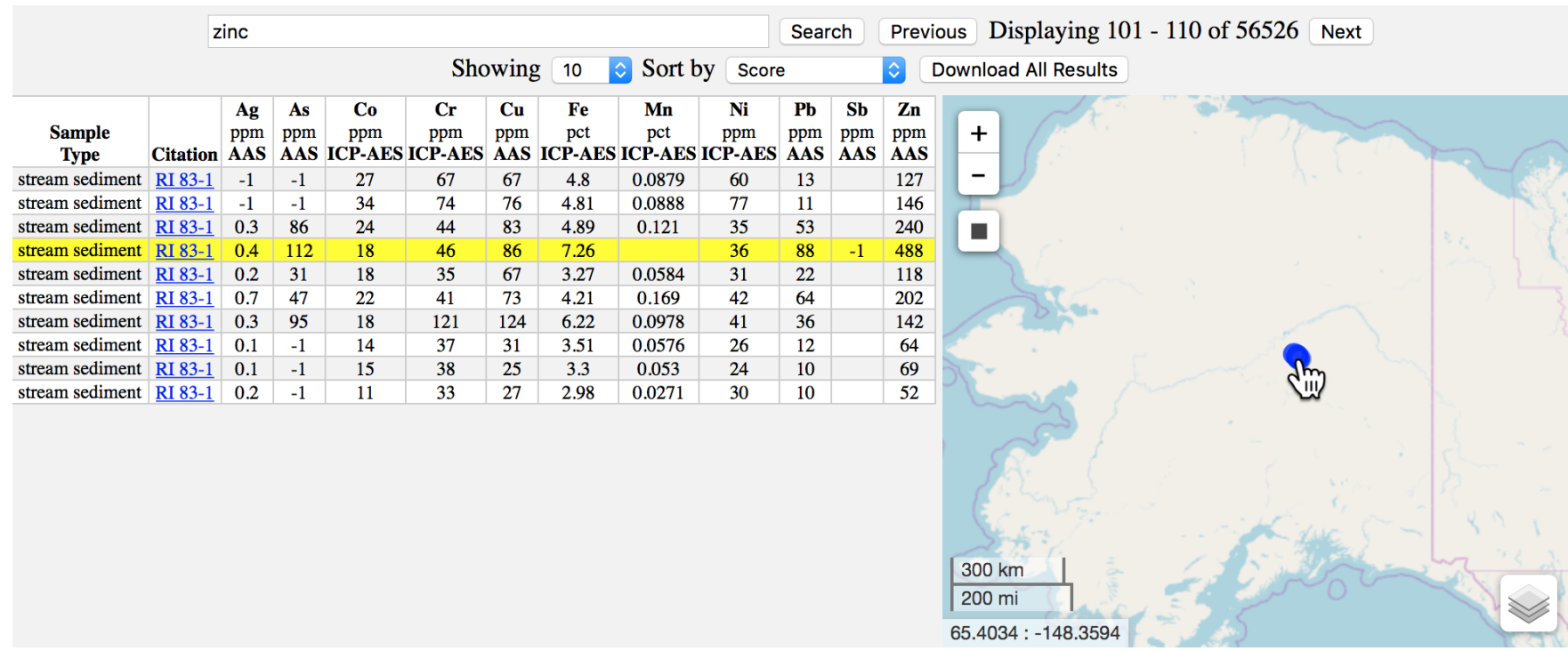




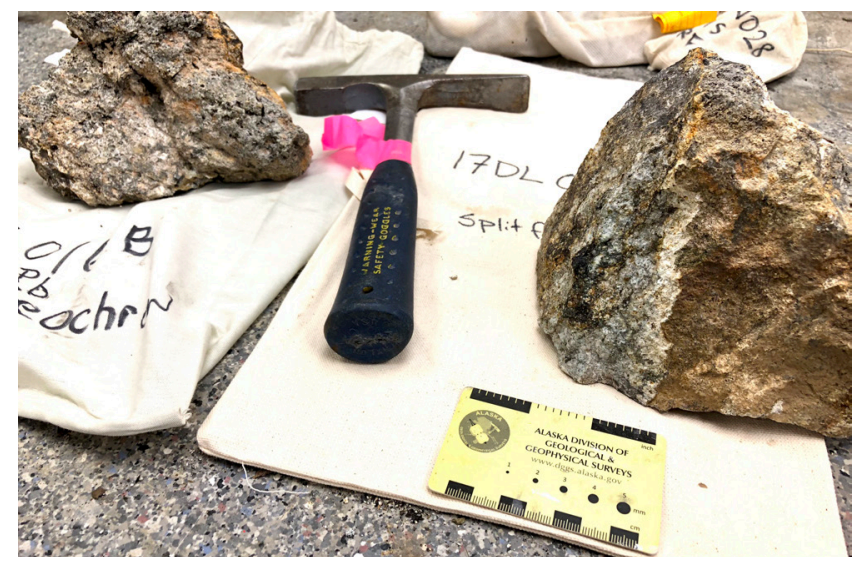

standardized in the agency, and the various formats of the Field Station and Sample Numbers will be programmatically and manually matched between the DGGS and GMC databases; a time-consuming, but necessary task.

As part of this project, GIC staff will also scan and digitize station locations from legacy field station maps to match with pre-2000 samples at the GMC. High-resolution scans of the field station maps will be made available to the public through the Alaska Geologic Data Index (maps.dggs.alaska.gov/agdi). The ability to provide baseline geologic data and access to samples from prior exploration efforts is a critical part of investing in the future of our state and crucial for researchers and exploration efforts to refine existing data and obtain a better understanding of our natural resources.

\section{BEHIND THE SCENES}

In the last year, Geologic Information Center (GIC) staff installed 896 terabytes of additional storage capacity and replaced existing, antiquated storage. These new systems currently store 510 terabytes of digital geologic data maintained at DGGS and use fault-tolerant distributed filesystems that vastly increase expandability. These open source file systems replicate data over multiple servers in a storage cluster maintaining data integrity and availability while duplicating the functionality of expensive, vendor-maintained storage systems for free.

GIC staff also installed a new, high-availability virtual environment. Once the physical-to-virtual migration is complete, these virtual systems should provide improved uptime as well as a reduction in management costs. Ultimately, these virtual systems will allow the staff to set up automatic failover between DGGS-managed server rooms in both Fairbanks and at the Geologic Materials Center in Anchorage.

A major back-end update was completed to the "Elevation Datasets in Alaska" web application (elevation.alaska.gov). As a result of the changes, the responsiveness of the interface and its mobile compatibility has been drastically improved. Server-side changes were made to better manage, add, and remove data. GIC staff also added a suite of quality assurance tools, such as checks for data integrity

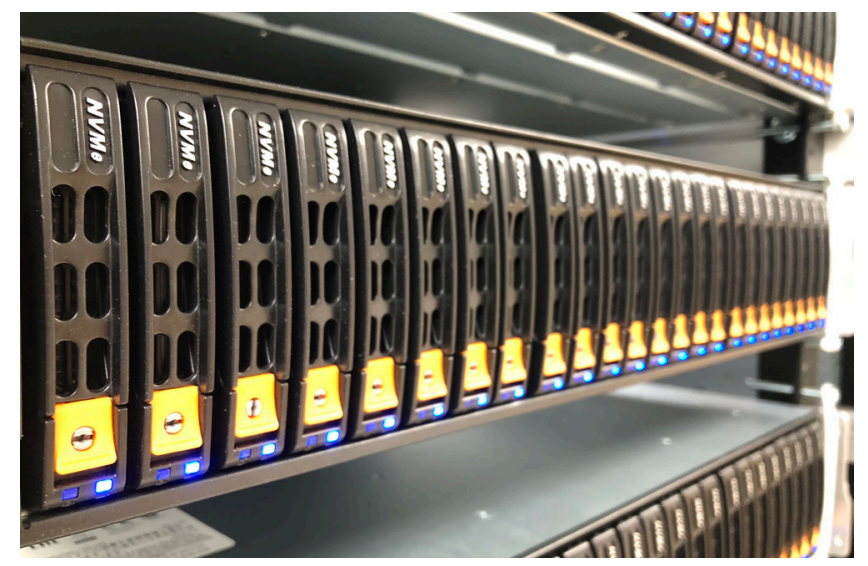

and validation of associated spatial objects. Similar updates also benefited other, existing web applications. For example, performance improvements have been made to both the "Geologic Photos of Alaska" (see above) and the GMC inventory system (maps. dggs.alaska.gov/gmc), the latter of which saw a $5 \mathrm{x}$ improvement in search performance.

Finally, our innovative new, web-based "Alaska Geochemistry" application is up and running. It's difficult to explain how different the application is from all of the other options on the Internet. GIC staff designed it so that its search options are expansive and simple - results are provided instantly, inline, and complete with values. The associated map shows you where each sample was collected and each sample record is highlighted in the data table when your mouse hovers over the matching sample location on the map, and vice versa. Results can be downloaded based on user-provided filters and exact search results can be shared via a dynamic URL, copied from your web browser. 


\section{NOTABLE ACHIEVEMENTS}

- Responded to nearly 426 email, mail, phone, and front desk inquiries for information about geologic maps, data, rock and mineral identification, and geologic hazards.

- Offered guidance to young students considering a career in the geosciences by volunteering at the UAF Careers of Science \& Math Opportunity Summit (COSMOS), featuring panel discussions with scientists and current science students, information on careers, education and funding options, and conversation opportunities with industry and governmental agencies.

- Helped organize and participate in the statewide Alaska Cross Content K-12 Educators Conference, featuring demonstrations and presentations from four DGGS staff about volcano hazards, earthquakes, coastal erosion, and climate research. Teachers were given ideas and educational material to help broaden citizen science and science outreach opportunities.

\section{DATA \\ The Alaska Division of Geological \& Geophysical \\ Surveys' Geologic Information Center (GIC) creates, preserves, and distributes publicly available geologic by the numbers maps, reports, and data to help improve the knowledge of Alaska's natural resources and geologic hazards}

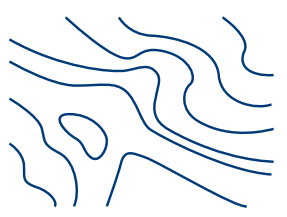

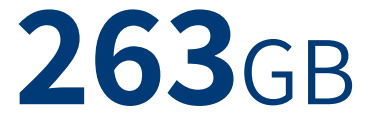

downloaded from elevation.alaska.gov per day
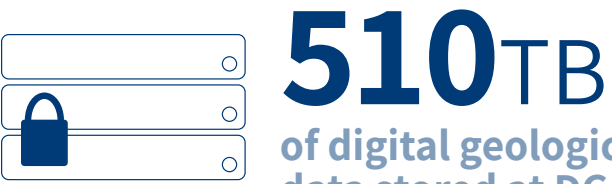

of digital geologic data stored at DGGS

\section{$1,846 \mathrm{mi}^{2}$}

of published, peer-reviewed geologic mapping

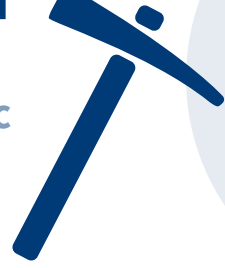

5,0

publications produced by DGGS since 1903
609,079

total number of items in the Geologic Materials Center inventory*

*An average Walmart Supercenter sells 160,000 unique items

\section{$1,263,569$}

Reports and datasets downloaded from dggs.alaska.gov

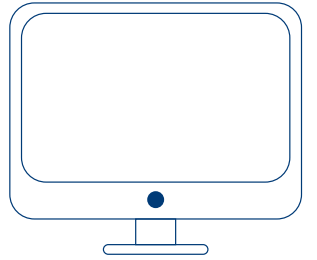

29.7 million

Total web page views at dggs.alaska.gov 


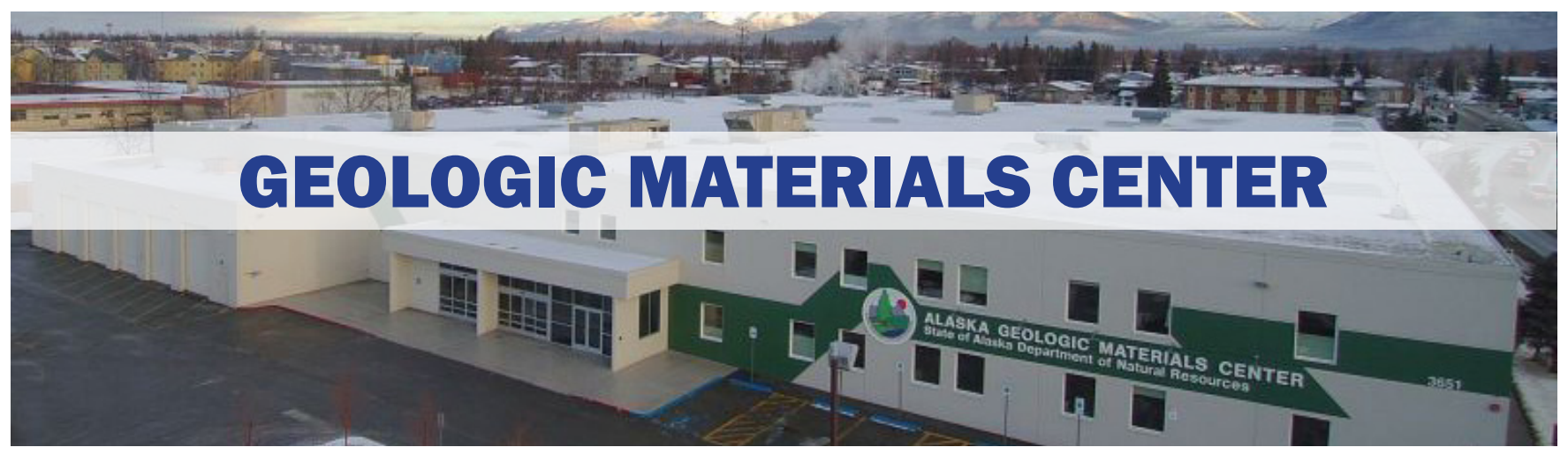

Permanently archive, index, protect, and make available for public inspection accessible geologic materials and related data to help advance exploration and knowledge of Alaska's natural resources.

\section{BENEFIT TO ALASKA}

Alaska is home to world-class discovered and undiscovered natural resources. The cores and samples stored at the Alaska Geologic Materials Center (GMC) provide baseline geologic data and are critical for resource management and exploration in the state. The information they provide will likely help discover new and additional oil and gas reserves, viable geothermal energy regions, or new mineral prospects, as they have in the past. One foot of core can provide critical information to an exploration or development company, potentially leading to discovery and ultimately to millions of dollars in revenue to the State as well as hundreds of local jobs.

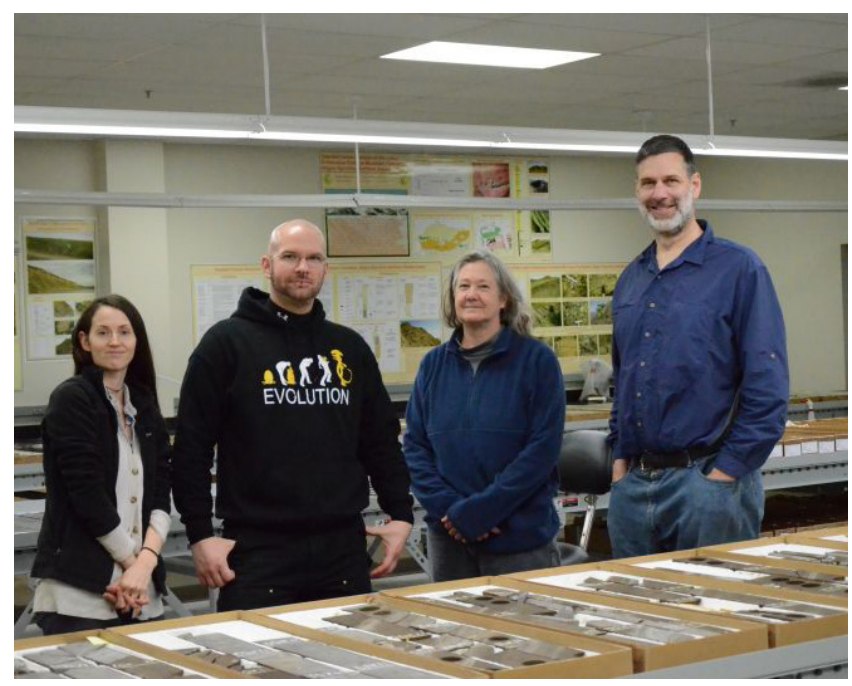

\section{OVERVIEW}

The GMC is the Alaska's largest and most comprehensive archive of geologic samples from offshore and federal, state, and private lands. It is the key entity directed to help industry, academia, and the public understand Alaska geology through the acquisition and preservation of physical and digital collections for future generations, assisting in the discovery of energy and mineral resources, and public outreach programs to illustrate the stories behind the science. The GMC is operated by the Alaska Department of Natural Resources, Division of Geological \& Geophysical Surveys (DGGS). Cooperative partnerships with State and federal agencies have centralized collections from the U.S Bureau of Land Management (BLM), U.S. Geological Survey (USGS), U.S. Bureau of Ocean Energy Management (BOEM), former agency U.S. Bureau of Mines (BOM), and Alaska Oil and Gas Conservation Commission (AOGCC) into one repository. Grants from the USGS-led National Geological and Geophysical Data Preservation Program (NGGDPP) have aided the GMC in ongoing tasks of completing inventories and generating a more comprehensive public, geologic collections database.

Alexandra Busk, Walter Zimmerman, Jean Riordan, Kurt Johnson 


\section{FEES FOR SERVICES INITIATED}

Foremost amongst changes this year was the implementation of Senate Bill 170 (Ch27 SLA2016) signed by Governor Bill Walker last year. The bill modified statute AS 41.08.030 ("Printing and Distribution of Reports") to include a new section AS 41.08.045 ("Fees for facilities, equipment, products and services to the statutes governing the DGGS"). Following extensive public and legal review, the new cost system balances public access to GMC services with requirements to secure funding to ensure the facility continues to operate, grow, and serve long into the future. This will be an adjustment for the facility's users, but the fees will help offset increased operational costs of the newly renovated, larger facility and benefit the public by improving sample accessibility and ensuring a higher quality and increased number of services provided.

\section{SEISMIC DATA RELEASE}

The most prominent new GMC service to support Alaska energy exploration was the release of six 2-D and 3-D seismic surveys across the North Slope and Cook Inlet. The geophysical datasets released to the state through the Alternative Credit for Oil and Gas Exploration (AS 43.55.025) and
Tax Credit for Certain Losses and Expenditures (AS 43.55.023) are eligible for public distribution after two to ten years following the completion of exploration activity. The datasets are available through the GMC after processing, quality control, and adjudication is done by the Division of Oil and Gas (DOG). Nominal fees charged to for-profit entities will help offset operational costs, while research and education uses of the exploration data are encouraged by offering the datasets to qualifying government, academic, and non-profit institutions at no cost.

\section{UNIVERSITY STUDENTS CONNECT WITH THE PUBLIC}

Education outreach at the GMC was highlighted by the third annual core study and public workshop organized by UAA Associate Professor of Geology Dr. Jennifer Aschoff. These stratigraphy labs are designed to challenge and extend the scientific capabilities of junior to graduate-level geology majors. The classes expose students to Alaska North Slope and Cook Inlet basin rock units and core samples from multiple wells are utilized to observe sedimentary rocks and use sedimentary structures, fossils, and rock compositions to determine likely depositional environments. To complement the analytical skills,

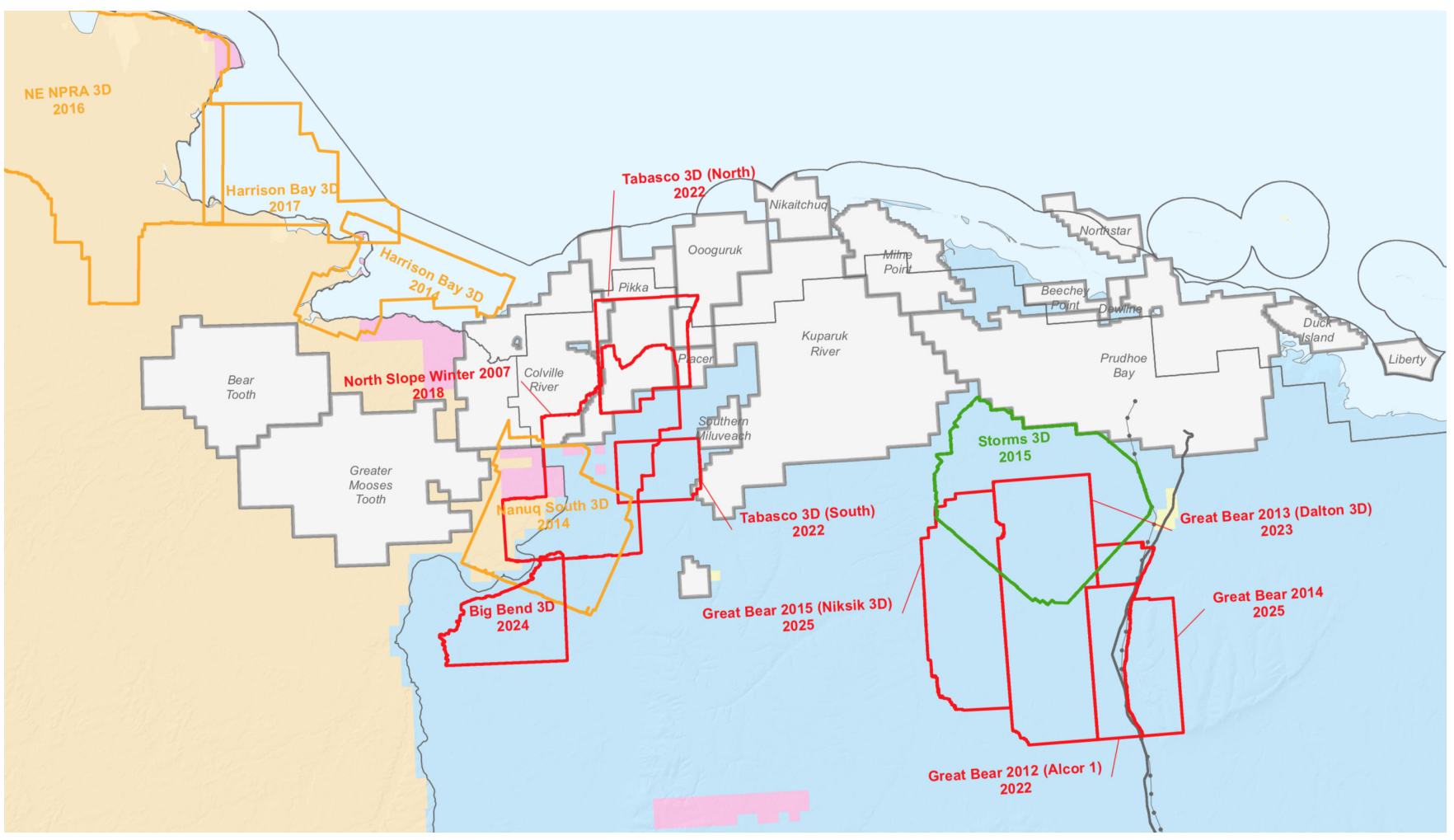


students present their results to members of the public and geologic community. This year, students shared their interpretations of a world-class package of deltaic sediments that hosted several major recent oil industry discoveries. The final open house allowed students to present and defend their observations and conclusions in a poster session with judges from local institutions.

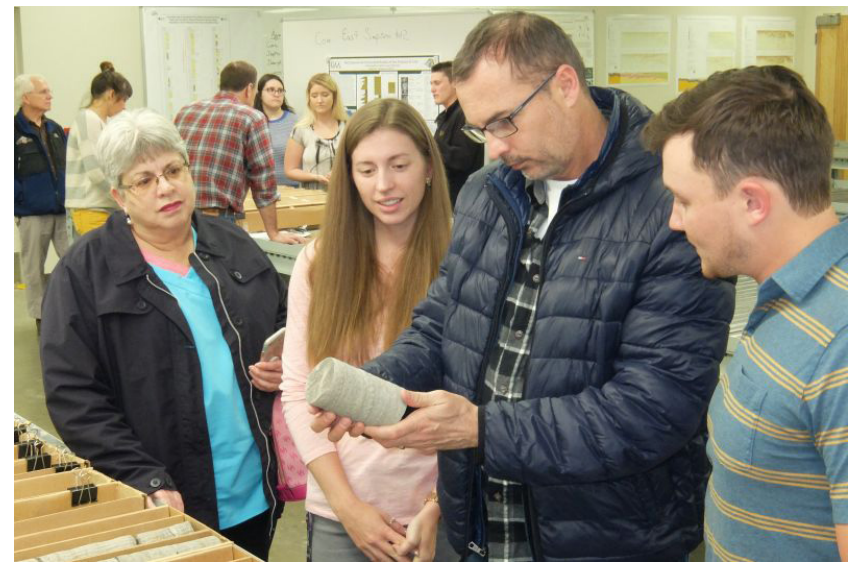

Above: Members of the public attend an open house at the GMC.

Below: Map showing the locations of heavy minerals in the Icy Cape District.

\section{A NEW HOPE OR THESE ARE THE HEAVY SANDS WE'RE LOOKING FOR}

The cyclical minerals industry showed glimmers of renewed activity in 2016 with visits by Kenorland Minerals and Millrock Resources. Visits by companies in the recent past provided preliminary evidence for potentially economically recoverable heavy minerals on Alaska Mental Health Trust lands (TLO) near the Icy Cape region of Southeast Alaska. TLO evaluation of the GMC "heavy" sands found potential for industrial heavy minerals placers such as garnet, zircon, rutile, magnetite, and epidote as well as the potential for gold placers as co-or by-product.

\section{AMBASSADOR TO ALASKA GEOLOGY}

\section{The Public Interest in Rocks}

Alaska's interest to protect and support its stability and prosperity is a challenging set of tasks. The GMC encompasses unique qualities to publically support these goals on individual, state, national, and international levels. This year, the GMC assisted the Alaska Gasline Development Corporation by hosting dignitaries from the Beijing office of the Sinopec oil

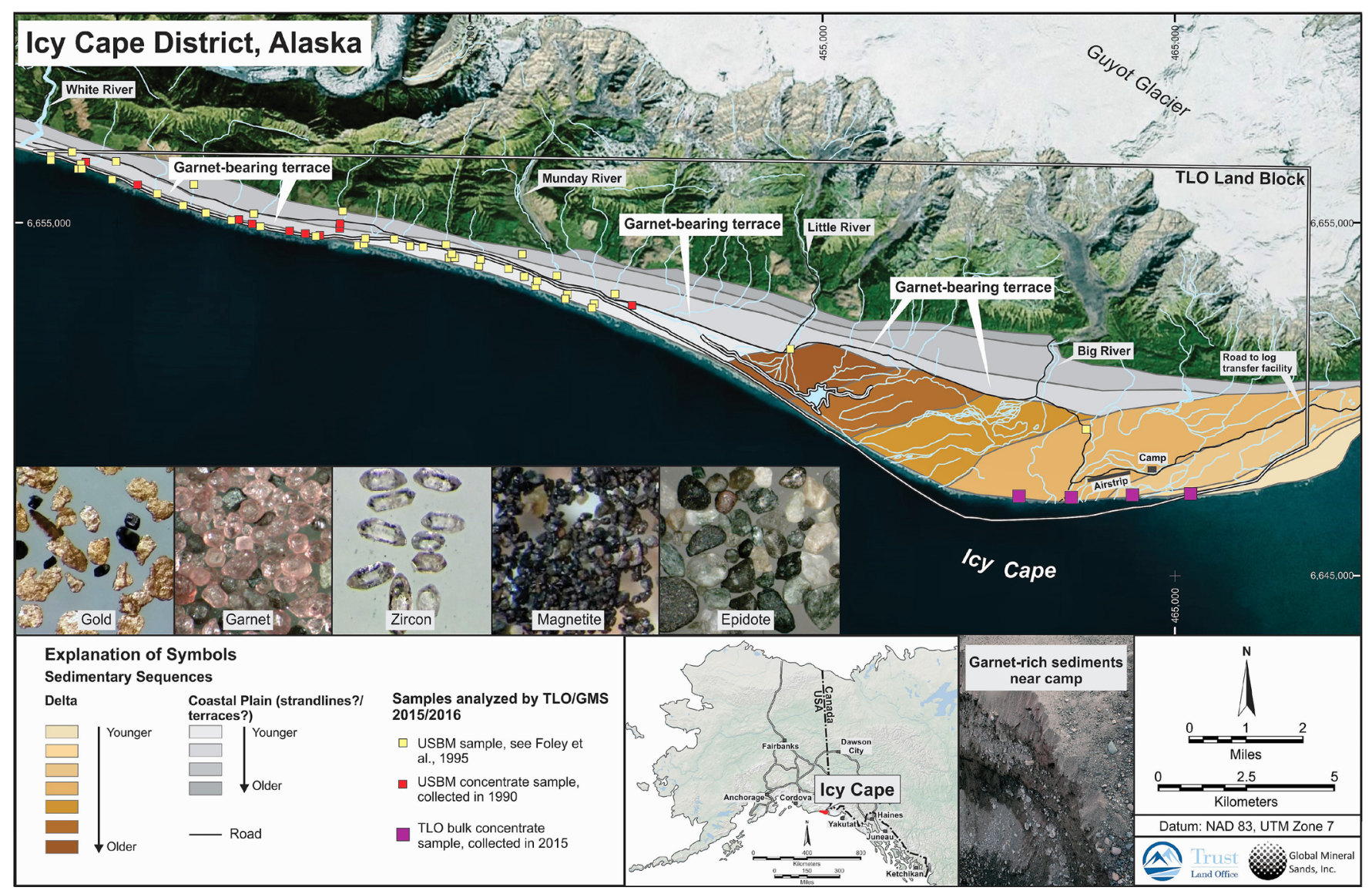


company and the Bank of China. Delegates observed core samples ranging from the original Prudhoe Bay State 1 discovery well to the latest North Slope energy breakthroughs. The delegates were also introduced to rock materials representing the vast number of mineral prospects located on state land.

Federal policy has extended effects on Alaska's state interests. In partnership with the U.S. Geological Survey, the GMC hosted two federal tours comprised of a team of Washington D.C. Congressional staffers and the Department of Interior Acting Assistant Secretary for Water and Science.

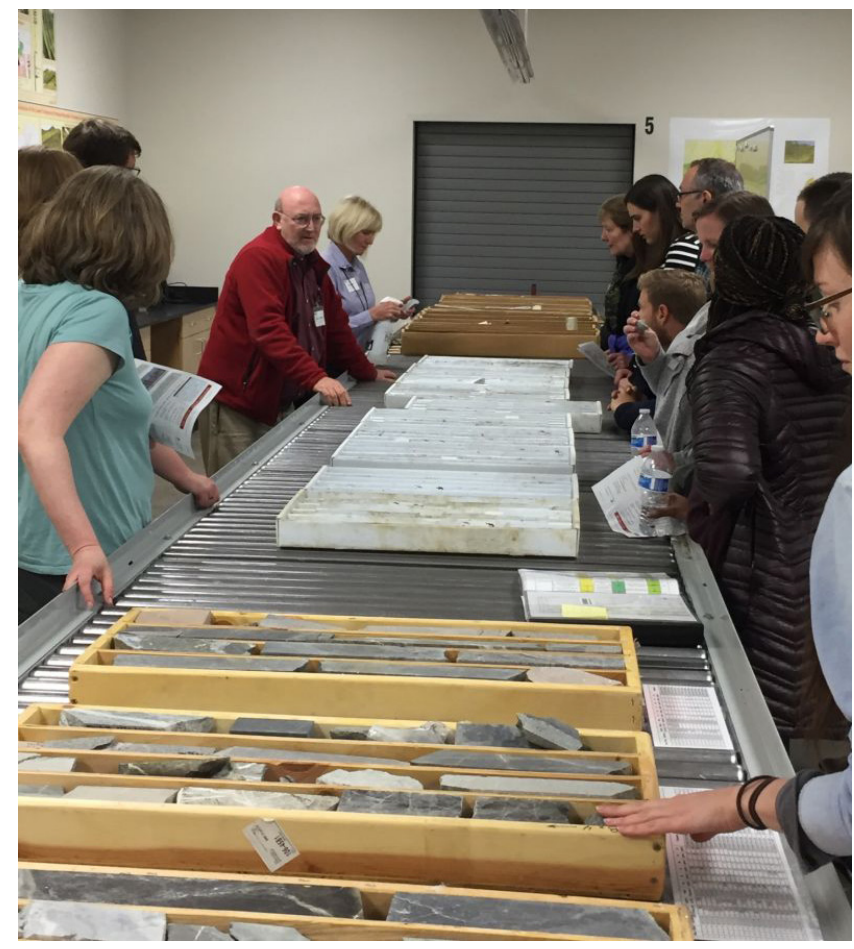

\section{New Energy Plays, New Energy Players}

Several major exploration successes over the last several years by Repsol USA and ConocoPhillips Alaska had their roots in the GMC sample archives. Both companies utilized North Slope drill samples stored at the GMC to support petroleum exploration that resulted in the subsequent recent discoveries of multiple reservoirs that may reach 220,000 barrels of oil production per day.

Recognizing the resource potential of the Nanushuk Formation, DGGS geologists utilized four GMC well core sets to host an American Association of Petroleum Geologists, Pacific Section workshop on this important new energy play. The well attended session immersed national and international representatives from twenty-two energy companies, universities, and government agencies into extensive field and research efforts by DGGS geologists involving the Nanushuk formation and its regional geologic context.

Geologists from independent and major energy companies visited the GMC to sample and examine hundreds of feet of well core and cuttings. As production declines within the mature Prudhoe Bay oil field, it is essential to diversify the oil industry in Alaska. The GMC hosted visits by major and independent oil companies and government researchers operating in both the North Slope and Cook Inlet regions, including ConocoPhillips, Hillcorp, Glacier Oil \& Gas, Alaska Gasline Development Corporation, U.S. Geological Survey, U.S. Department of Energy, and the U.S. Bureau of Ocean Energy Management.
Above: Visitors from the Department of Interior visit the GMC.

Right: Attendees of the American Association of Petroleum Geologists' Pacific Section workshop. Workshop attendees included representatives from twenty two energy companies, universities, and government agencies.

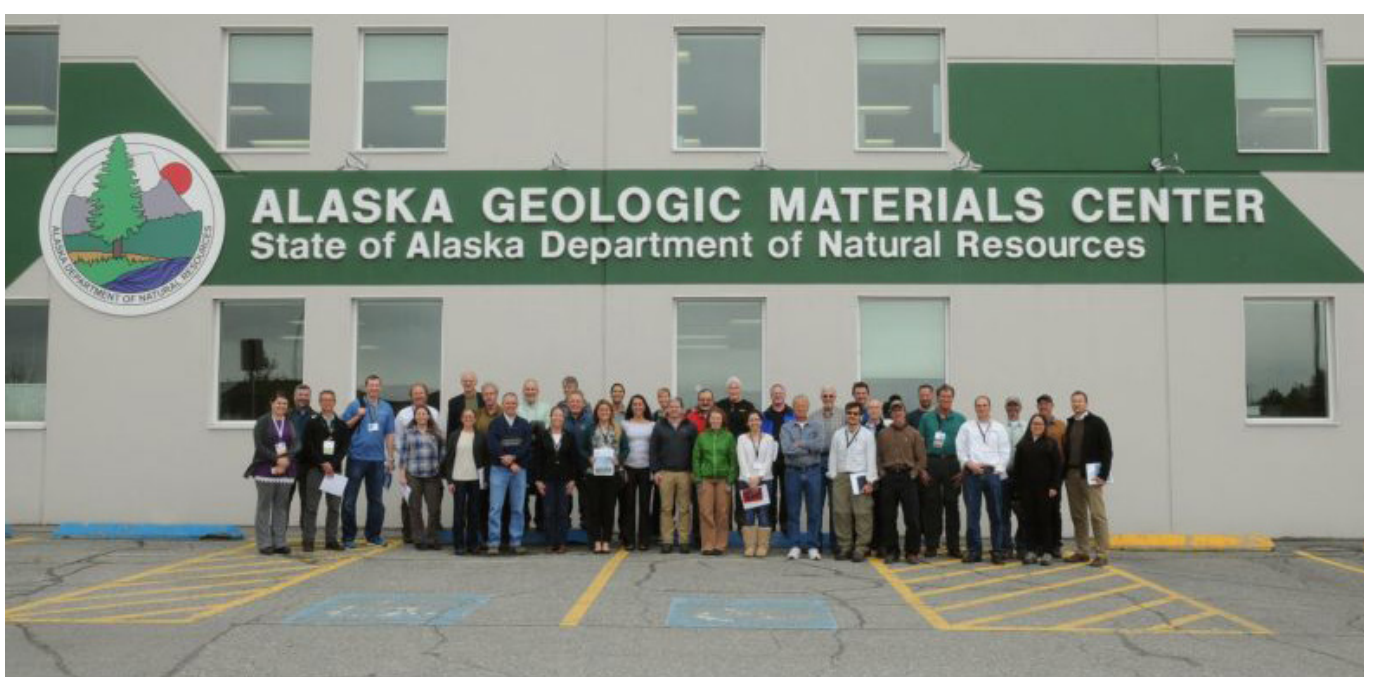




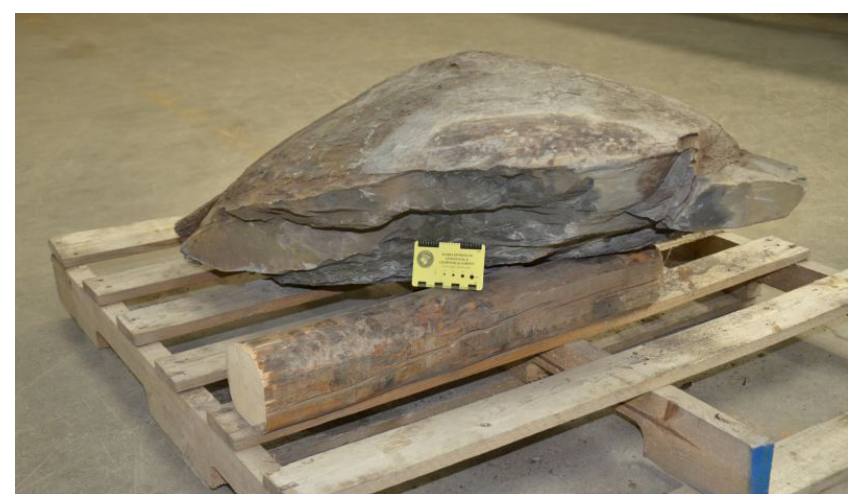

\section{If They See It They Will Come}

GMC tours are very popular with Alaska residents, professionals, and students, with small to large public group requests to tour the facility occurring weekly. Visitors learn about mega-thrust earthquakes, see what rocks look like under hi-power microscopes, handle common rocks and (not-so-common) fossils, and begin to experience how geologists view the planet. Despite hosting 36 public tours in FY2017, the small GMC staff doesn't allow for tours to be actively promoted, but the relocation to Anchorage has greatly increased community visibility and curiosity about the facility.

Extending beyond tours and workshops in Anchorage, the GMC takes knowledge of its large geologic collections and professional expertise to the geologic community at-large. GMC collections played its part in the State of Alaska booth at the NAPE exposition in Houston, Texas to promote Alaska energy resources and infrastructure to international attendees. In Salt Lake City, GMC staff presented the initial talk at the 2017 U.S. Geological Survey and Association of American State Geologists Data Rescue and Preservation Workshop. The 2015 GMC facility relocation demanded drastic IT infrastructure and data management upgrades to track the real-time transfer of more than 100,000 boxes between two distant facilities. The presentation outlined how migration to a modern SQL database affects almost all aspects of GMC collections management and enables procedures that boost performance and increase public access to the rock inventory.

\section{FINDING A BLACK CAT IN A COAL MINE}

\section{Sample Accessibility Boosted by Advanced Inventory Web Interface}

An integral part of the GMC is its robust database. Using barcodes and scanners, the system tracks each step of more than 160,000 sample containers as it is organized, audited, and displayed for visitors. The GMC developed and maintains a public, searchable web-map for more than 620,000 samples in its inventory. The browser-based tool (maps.dggs.alaska. gov/gmc) allows users to build simple or complex

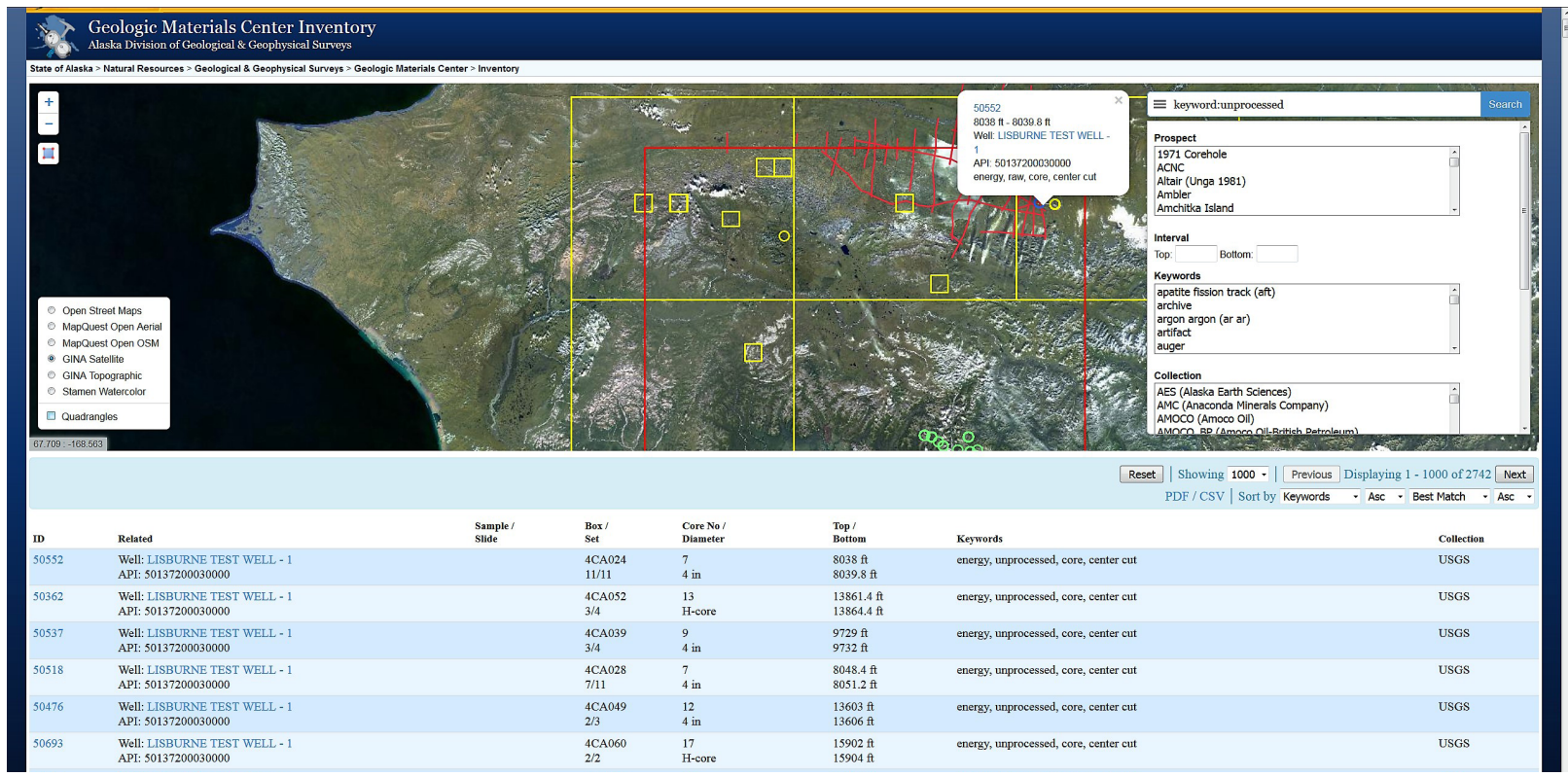

A screen shot of the GMC's database. Users can search the database (maps.dggs.alaska.gov/gmc) for more than 620,000 samples in the GMC's inventory. 
queries through a combination of Google-like text searches, dynamic user-defined boxes, map-based regions, and drop-down text filters. Each inquiry generates a search-specific URL that can be sent to GMC staff or colleagues to exactly replicate the user's inventory results. All user search results can be easily transformed into downloadable PDF or plain-text CSV files.

\section{COLLECTION HIGHLIGHTS: BELIEVE YOU CAN AND YOU'RE HALFWAY THERE}

\section{...significant donations continue to roll in!}

With the 100,000 square-foot Anchorage facility beginning its third year, the new repository surpassed the 51\%-full mark this year. Total collection box numbers has increased more than $50 \%$ over the last 30 months. Significant, new donations from oil and gas and mining industries, state agencies, Alaska Native corporations, and engineering firms continue to pour into the warehouse. This year, the IRF Group donated more than 3,200 palynology and kerogen slides to the GMC energy collections. Mining industry donations in 2017 from Cook Inlet

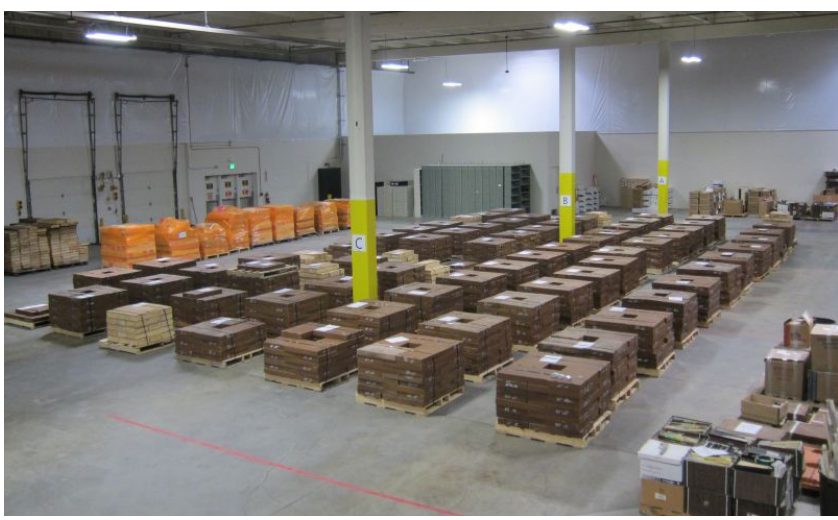

The GMC accepts donations of geologic samples from companies and organizations that might otherwise dispose of them.

Regional, Inc., Doyon, Limited, and Pacific Rim Geological Consulting, Inc. added more than 2,300 boxes of contiguous core for the underrepresented late Tertiary sections of the Cook Inlet Basin. The Alaska Volcano Observatory donated 15,000 volcanic outcrop samples from the Aleutian arc. Economic pressure often forces both private and government agencies to dispose of their geologic samples to reduce their storage fees. Donating samples to the Alaska GMC for public use is a responsible alternative to discarding invaluable geologic information.

\section{NOTABLE ACHIEVEMENTS}

- GMC staff has accessioned nearly 100,000 new samples this year.

- Both DGGS and GMC staff are cooperating to identify and connect metadata to more than 100,000 DGGS outcrop samples. GMC staff inventoried more than 15,000 additional samples, while DGGS staff looks to triple, from 20,000 to 60,000 samples, the number of GMC samples with associated DGGS digital metadata.

- Two GMC internships provided practical geologic training and extensive work exposure to assisting professional Alaska geologists.

- Volunteer projects completed data entry of 15,000 foraminifera slides, continued conservation work to fix detached labels on 1,800 palynology slides, and provided preliminary inventory of hundreds of megafossils from the Shell Oil outcrop collection.

- Eight unknown GMC "Mystery Core" mineral prospects were identified by Alaska prospectors at the DGGS Minerals Section booth at the Alaska Miners Association convention in Anchorage.

- GMC client visitors are estimated to reach 1,090 persons this year, about a $\mathbf{5 8 \%}$ increase over 2016.
3,096 Alaska oil \& gas wells
$26,500,000$ feet of oil \& gas strata drilled
$16,700,000$ representative feet of oil \& gas core and cuttings
76,000 linear feet of oil \& gas core
2,200 Alaska mineral boreholes
$\mathbf{7 6 6 , 0 0 0}$ feet of mineral rock drilled
617,000 representative feet of mineral core and cuttings
$\mathbf{3 5 4 , 0 0 0}$ linear feet of mineral core
214,000 processed slides and thin sections 


\section{MINERAL RESOURCES SECTION}

\section{BENEFIT TO ALASKA}

The Mineral Resources Section improves the success of exploration and mine development in Alaska by providing accurate, timely, and readily available geological, geophysical, and mineral deposit information for Alaska's lands, and assess the mineral resource potential of Alaska's 160 million acres of land in support of the $\$ 3.2$ billion per year mining industry, and its 2,900 direct jobs.

\section{YEARS OF THE AIRBORNE GEOPHYSICAL \& GEOLOGICAL MINERAL INVENTORY PROGRAM}

Since 1993 the data products of the DGGS's Airborne Geophysical \& Geological Mineral Inventory (AGGMI) program have been important tools to facilitate industry's successful mineral-exploration programs in Alaska. AGGMI products have contributed to private-sector discovery of more than 22 million ounces of gold in the Salcha River-Pogo and Livengood areas since 2004. Freegold Ventures Limited used AGGMI magnetic data to target drill holes and stake claims on their Shorty Creek project (2014-2016). Similarly, Endurance Gold used AGGMI magnetic and resistivity data to target drill holes on Elephant Mountain (2016-2017), and White Rock Minerals Ltd. used AGGMI geophysical data and the DGGS geologic map of the Bonnifield area to stake claims and identify future exploration targets. Airborne geophysical datasets are used to assist geologic mapping of an area, particularly in areas with poor bedrock exposure. Mineral companies routinely use DGGS

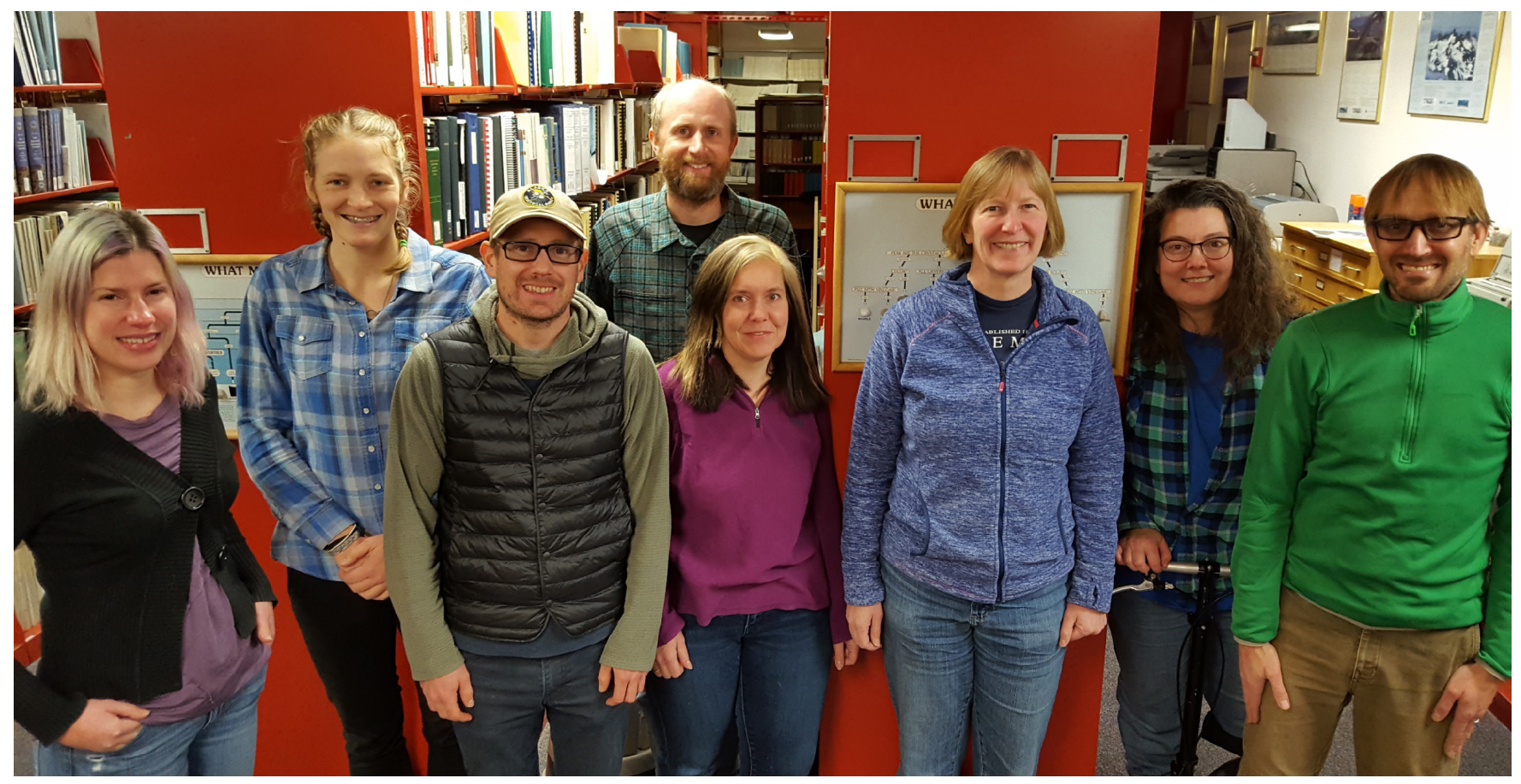

Alicja Wypych, Karri Sicard, Travis Naibert, Evan Twelker, Jen Athey, Melanie Werdon, Gina Graham, Abraham Emond 


\section{DGGS PROJEGT SPURS EXPLORATION AGTIVITY IN THE TOK RIVER AREA}

Maps, reports, and datasets produced by the DGGS Mineral Resources section provide important information that helps to attract mineral exploration companies to invest in Alaska.

DGGS identified the Tok River area (fig. 1), 20 miles southwest of the community of Tok, as an area of high potential for undiscovered gold, zinc, copper, lead, silver, and antimony. We began our investigation of the area with an airborne geophysical survey in 2014, followed by fieldwork by section geologists in 2015 and 2016. Data products include geochemical assays, a detailed geologic map, radiometric age dates, and descriptions of mineral occurrences encountered. Many areas of Alaska have poor coverage of these datasets, which are essential to attract and guide mineral exploration companies.

This work began to pay off within weeks of DGGS releasing the Tok River geochemical reports in November 2016. Following the publication, Peak Gold LLC, operators of the nearby Tetlin gold-copper-silver exploration project, staked an additional 436 mining claims, totaling 68,680 acres. To hold the claims, the company will pay approximately $\$ 60,000$ in annual rental, and the exploration of these new claims is already generating economic activity in the region. Discovery of a minable resource would mean further economic development and tax revenue.

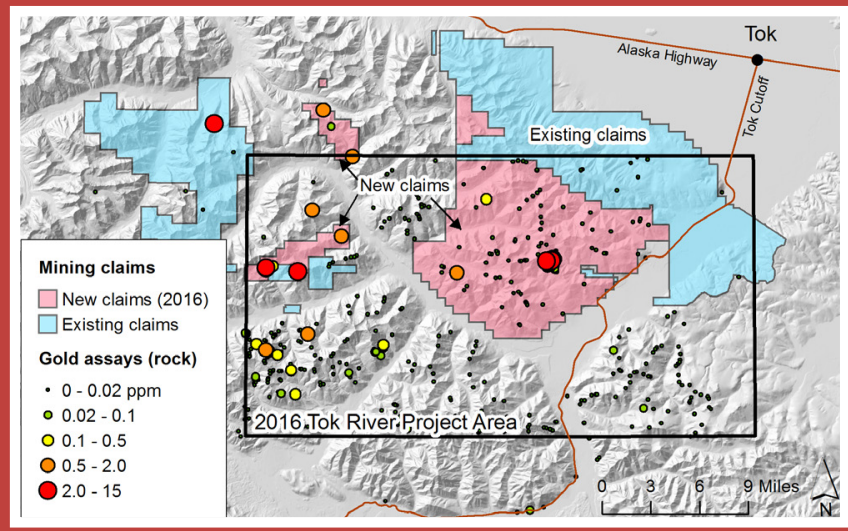

Above: Location of the DGGS Tok River Project, assay results, and new mining claims staked.

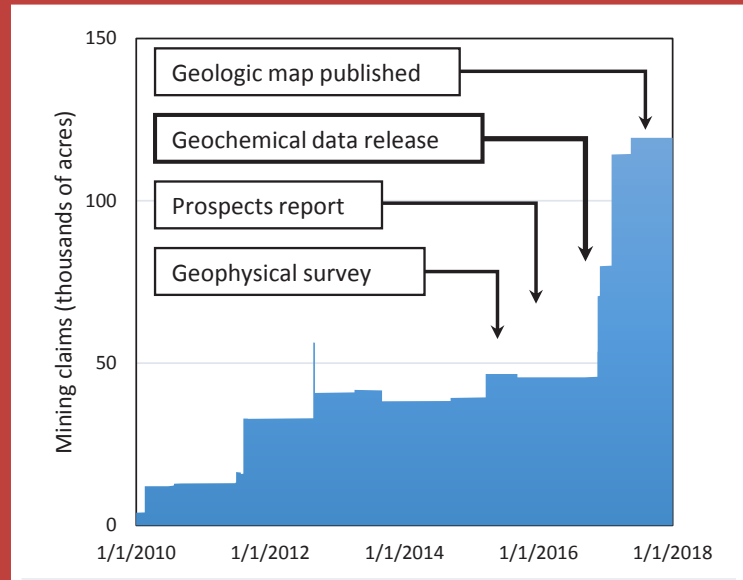

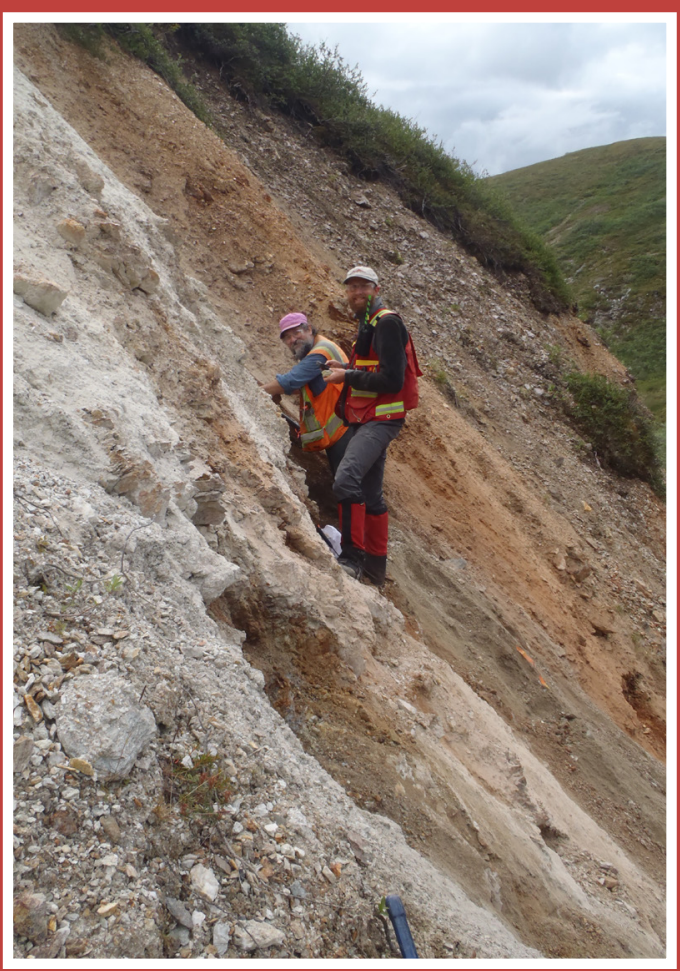

Above: DGGS geologists Evan Twelker (right) and Rainer Newbury. Photo: Sam Dashevsky.

Left: Timeline of mining claims activity and DGGS data releases. 
airborne geophysical surveys, geologic maps, and geochemical data to guide their more-detailed exploration work, which is necessary to make economic mineral discoveries. Exploration, discovery, and resource development contribute significantly to diversifying and building State's economy, tax revenue, and job creation. The AGGMI datasets also advance the State's knowledge of its mineral resources, and promote informed state, federal, and native corporation landand resource-management decisions.

\section{GEOLOGIC MAPPING OF MINERAL DISTRICTS: TANACROSS AND UNCLE SAM'S GOLD}

In 2017, Mineral Resource geologists completed fieldwork for year one of a two-year geologic mapping and geochemical sampling project covering 250 square miles in the northeastern Tanacross quadrangle adjacent to Yukon, Canada. The purpose of this project is to evaluate the area's mineral-resource potential and to create a geologic map to help guide industry exploration efforts. The area contains known porphyry gold-copper-molybdenum systems, which are newly recognized to be spatially associated with high-angle fault systems, many of which can

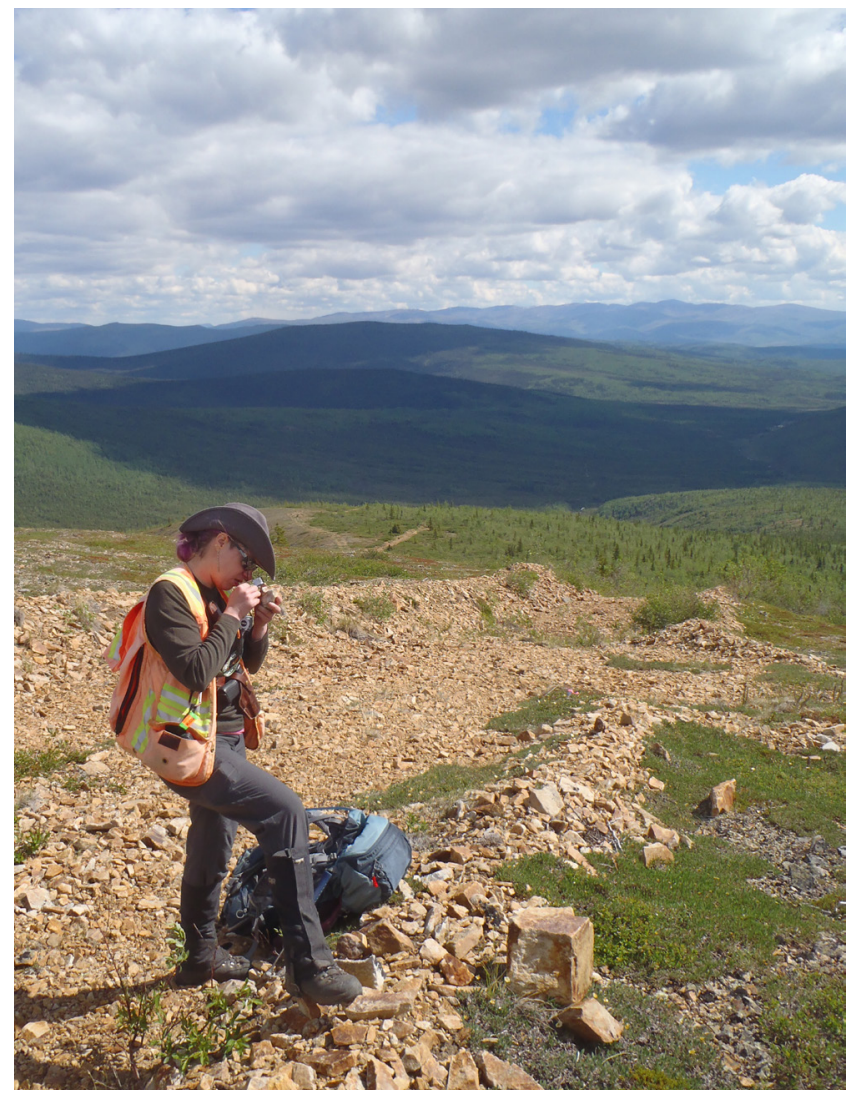

be directly identified in DGGS airborne geophysical surveys of the area. Ongoing work in FY2018 includes synthesis and interpretation of field data, writing a federally-funded proposal, and preparing for a second season of geologic mapping in summer 2018.

Mineral Resource geologists also completed fieldwork for year one of a two-year geologic mapping and geochemical sampling project in the Richardson-Uncle Sam gold exploration area northwest of Delta Junction. The 2017 portion of this mapping project covered an area of 250-square miles (figure 3 Richardson_MiniMap), which utilized DGGS’s East Richardson geophysical survey to facilitate mapping in this heavily vegetated area with abundant loess and sand dune cover. The purpose of this project is to integrate geological, geophysical, and mining industry datasets to create an improved geologic map that will guide exploration and help to determine the area's mineral-resource potential, based on known mineral systems and proximity to the Pogo gold mine. Ongoing work in FY2018 includes synthesis and interpretation of field data and preparations for a second season of geologic mapping in summer 2018.

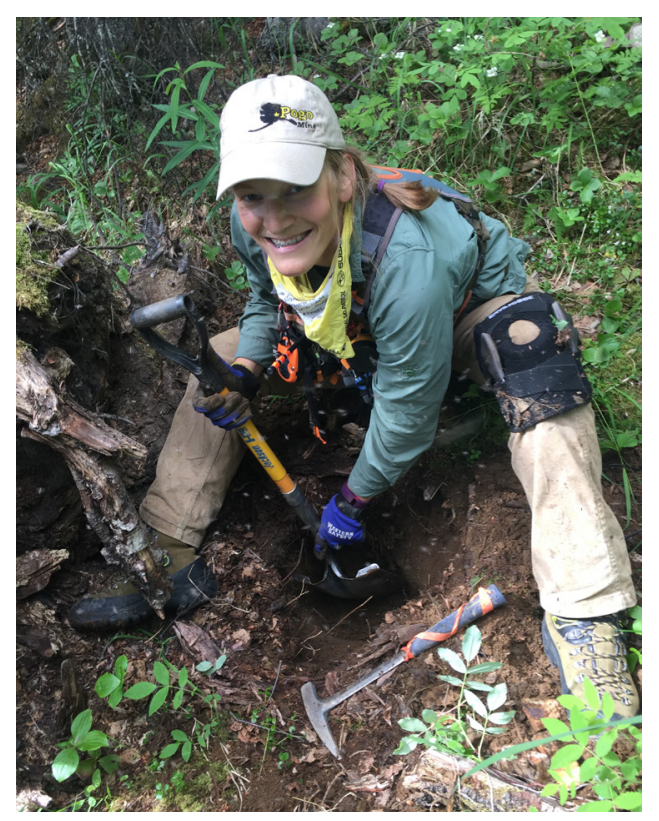

Above: DGGS geologist Karri Sicard performs field work in the Richardson-Uncle Sam gold exploration area northwest of Delta Junction.

Left: DGGS geologist Alicja Wypych examples a sample in the northeastern Tanacross quadrant, adjacent to Yukon, Canada. 


\section{EVALUATION OF THE TOK RIVER AREA}

In 2015 and 2016, Mineral Resource geologists completed 480-square miles of detailed geologic mapping and geochemical sampling in the Tok River area of the eastern Alaska Range just south of Tok. The purpose of this 2-year project is to evaluate the mineral-resource potential of the Tok River area; adjacent lands host volcanogenic massive sulfidetype base-metal deposits, copper-gold skarns, and structurally controlled gold-bearing veins. Within the project area, there are intrusion-related copper-gold prospects, other base-metal prospects of uncertain origin, and placer gold occurrences. DGGS documented 20 mineral occurrences not previously part of the public record, and following publication of the state-funded airborne geophysical survey and geochemical datasets, industry staked about 76,500 acres of claims on state land in the area, which increased state revenue through mining claim fees. DGGS work in FY2018 includes publishing the final geologic map, geochronologic reports, and mineral-occurrence summaries.

\section{GEOPHYSICS: THE SECOND "G" IN DGGS}

In FY2017, Mineral Resources staff worked on a number of engineering geology and minerals-related geophysics projects statewide. DGGS was contracted by the U.S. Geological Survey's Minerals Program to manage a fixed-wing magnetic survey in Porcupine River area of northeastern Alaska covering parts of the Colleen, Black River, and Charley River quadrangles. This federally funded, 5,500-square-mile survey was flown in late FY2017 and will be published by DGGS in FY2018. The Alaska Mental Health Trust Land Office contracted DGGS to manage a detailed airborne magnetic survey for the Icy Cape area, near Yakutat, as part of their Icy Cape Gold and Industrial Heavy Minerals project. This survey will be published after a 5-year confidentiality period expires.

DGGS geophysicists continued to work with DGGS Engineering Geology staff on the Goldstream permafrost project near Fairbanks, which is a cooperative project with the University of Alaska, Fairbanks, and a project with the Department of Transportation involving the Yukon River bridge crossing; both projects have geophysical surveys planned for publication in FY2018. Additionally, a portion of the DGGS Airborne Geophysical \& Geological Mineral Inventory program's VHS-format flight videos, collected as part of historical geophysical surveys, were converted into digital video files to create a long-term archive, and will be published with their associated surveys starting in FY2018. DGGS also hired a permanent geophysicist, Abraham Emond, to manage geophysics projects, after a 21 -month period without a permanent staff member.

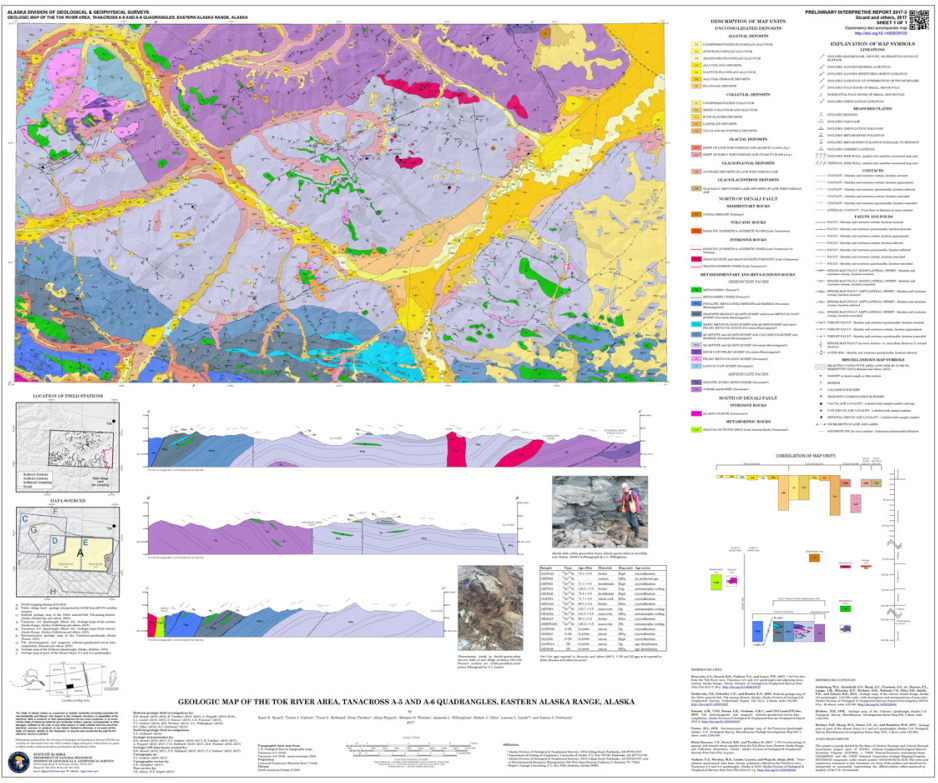

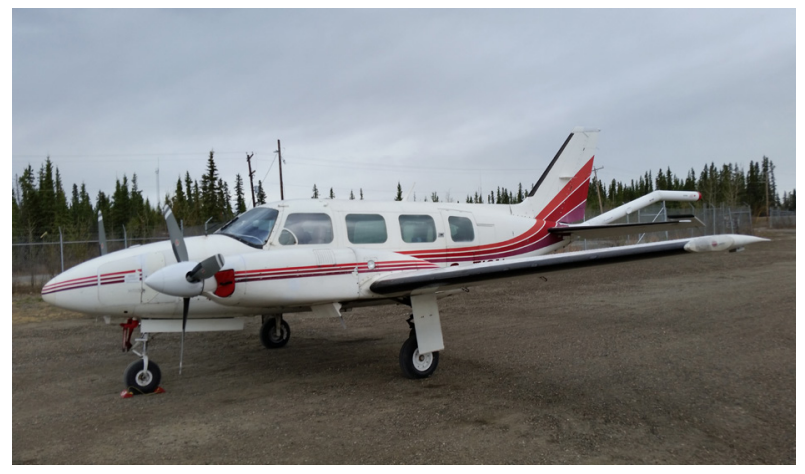

Above: The minerals section performed a fixed-wing magnetic survey in the Porcupine area in northeastern Alaska.

Left: The geologic map of the Tok River area, along with geochronologic reports and mineral-occurrence summaries, were published in 2017 


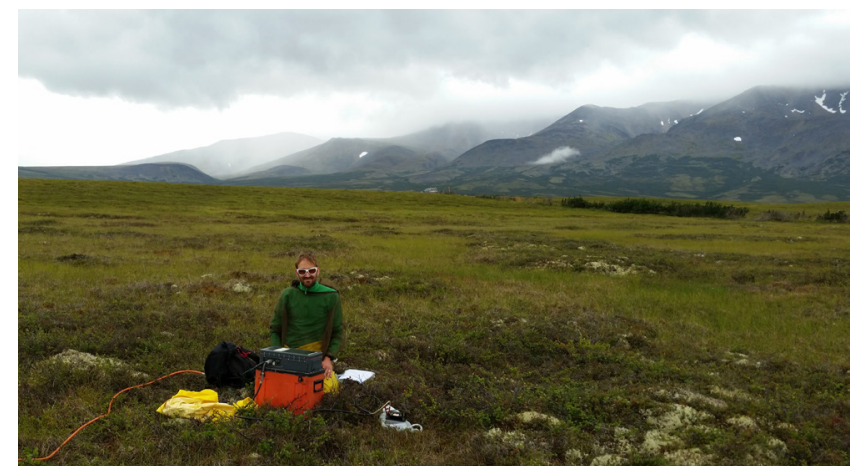

Geologist Abraham Emond joined DGGS as a permanent geophysicist in 2017.

\section{SHOWCASING ALASKA'S DIVERSE AND SUBSTANTIAL MINERAL POTENTIAL}

By publishing Special Report 72 "Alaska's Mineral Industry 2016," (dggs.alaska.gov/pubs/ $\underline{\mathrm{id} / 29748)}$ and by presenting annual overviews of mineral companies activities in Alaska at national and international mineral-industry conferences, the division fulfilled DNR's statutory requirement to "... conduct a continuing survey of the mineral resources and mining operations of the state and shall disseminate information regarding them..." (AS 27.05.050) and to "...make an annual report to the governor on all essential matters with regard to mining in the state"(AS 27.05.060). DGGS distributed more than 350 print copies of the 37 th annual minerals report and its 435 downloads during 2017 indicate that this is a vital publication. Alaska is perennially recognized as having high mineral-resource potential and a healthy mining economy equal to that of many countries, but Alaska is competing to attract international mineral exploration investment with neighboring provinces and other U.S. states that have more developed infrastructure and perceived lower risk. The Alaska Mineral Industry Report and presentations to the mineral industry at mining conferences are the primary vehicle for demonstrating that Alaska has a diversity and quantity of mineral potential and an investment climate competitive with British Columbia, Yukon, Nevada, and Arizona as well as many countries.

\section{EVALUATING ALASKA'S RADON POTENTIAL}

According to the Alaska Division of Public Health, radon is an under-recognized health risk in the state. In October 2016, the Environmental Protection Agency's Environmental Information Exchange Network funded a 3-year project for DGGS to create an Alaska radon database and compile statewide radon test results. The goals of the project are to create an online mapping application to help the public visualize potential radon risk and develop an enterprise database model for geologic map data in collaboration with other state and federal geologic agencies. In the first year of the project, DGGS compiled 2,020 radon test results, and geologists and GIS professionals from 10 state geological surveys, the USGS, and the Geological Survey of Canada met monthly for the Collaborative Database Effort for Geology (CDEFG) workgroup to work toward the development of the national geologic database model which DGGS is prototyping.

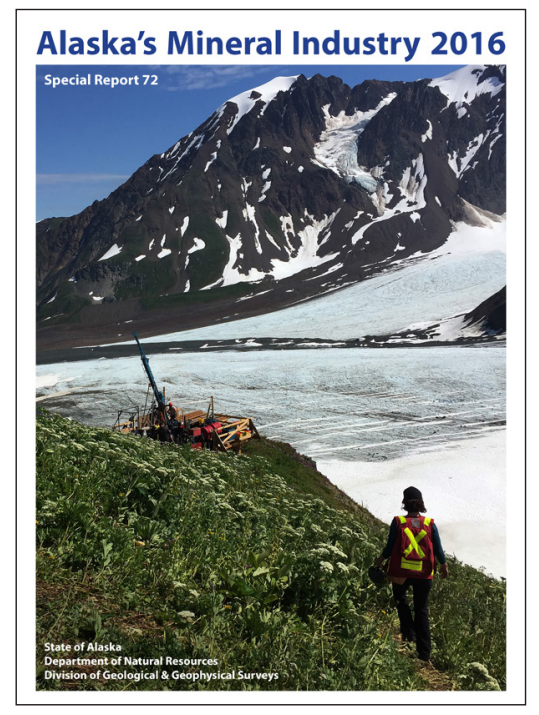

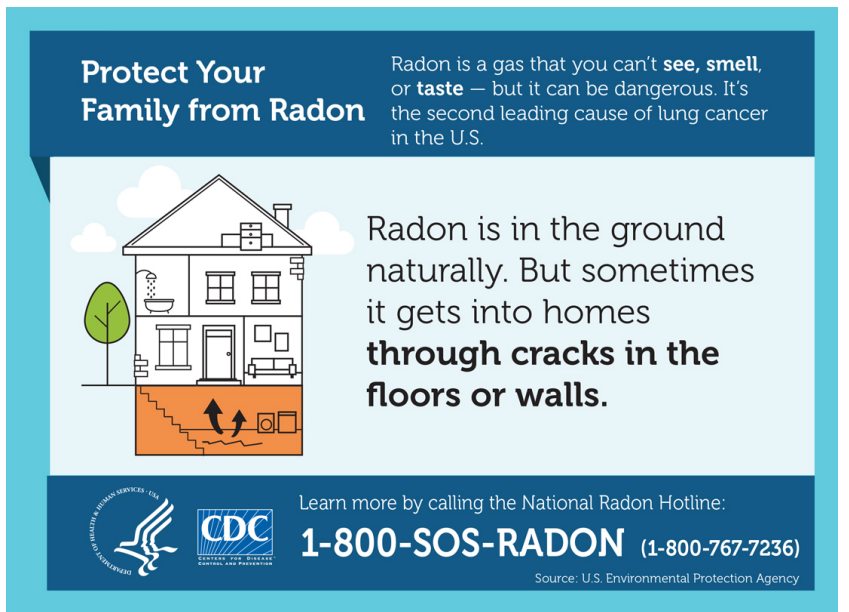

Left: The 37th annual minerals report presents annual overviews of the mineral industry in Alaska.

Right: DGGS scientists are currently working on a three year project to create an Alaska radon database. 


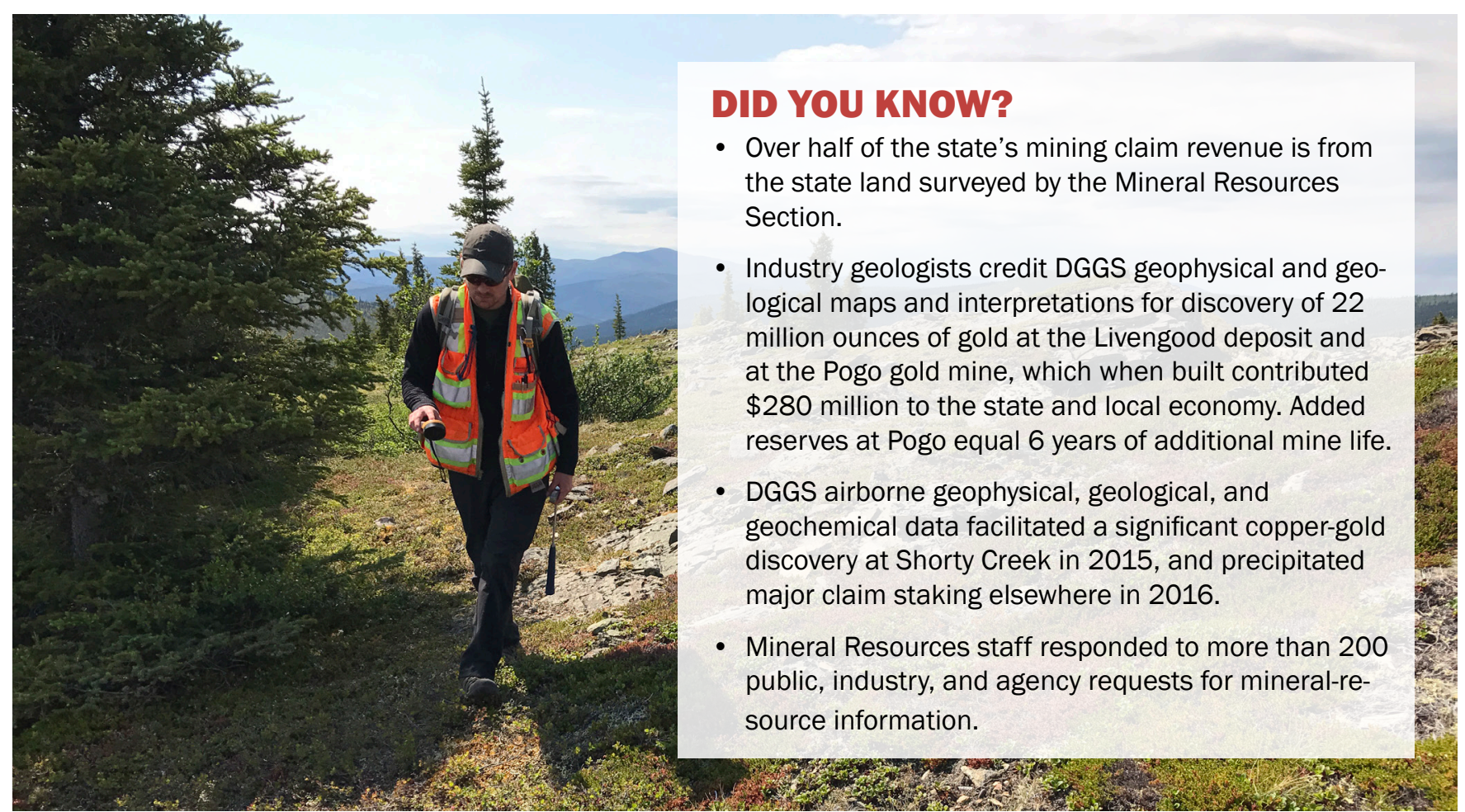

\section{MINERALS RESOURCES 2017 PUBLICATIONS}

Athey, J.E., 2017, 2017 Data Stewardship Survey results: Alaska Division of Geological \& Geophysical Surveys Raw Data File 2017-3, 3 p. http://doi.org/10.14509/29726

Athey, J.E., and Werdon, M.B., 2017, Alaska's mineral industry 2016: Alaska Division of Geological \& Geophysical Surveys Special Report 72, 65 p. http://doi.org/10.14509/29748

Benowitz, J.A., Layer, P.W., Wypych, Alicja, and Freeman, L.K., $2017,{ }^{40} \mathrm{Ar} /{ }^{39} \mathrm{Ar}$ ages of rocks collected from the Passage Canal area, Seward D-7 Quadrangle, Alaska: Alaska Division of Geological \& Geophysical Surveys Raw Data File 2017-4, 6 p. http://doi.org/10.14509/29721

Benowitz, J.A., Layer, P.W., Wypych, Alicja, and Twelker, Evan, 2017, ${ }^{40} \mathrm{Ar} /{ }^{39} \mathrm{Ar}$ data from rocks collected in the 2015 Wrangellia mineral assessment project area, Mount Hayes A-5, Mount Hayes B-6, and Talkeetna Mountains D-2 quadrangles, Alaska: Alaska Division of Geological \& Geophysical Surveys Raw Data File 2017-1, 9 p. http://doi.org/10.14509/29699

Benowitz, J.A., Sicard, K.R., Naibert, T.J., and Layer, P.W., 2017 , ${ }^{40} \mathrm{Ar} /{ }^{39} \mathrm{Ar}$ data from the Tok River area, Tanacross A-5 and A-6 quadrangles and adjoining areas, eastern Alaska Range: Alaska Division of Geological \& Geophysical Surveys Raw Data File 2017-5, 26 p. http://doi.org/10.14509/29727

Blessington, M.J., Werdon, M.B., Seitz, S.S., and Mulliken, K.M. 2016, Digital compilation of geochemical data for historical samples from occurrences of strategic and critical elements in Alaska: Part I - Rare-earth elements (REE): Alaska Division of Geological \& Geophysical Surveys Raw Data File 2016-11, 4 p. http://doi.org/10.14509/29473

Naibert, T.J., Werdon, M.B., Lande, Lauren, and Wypych, Alicja, 2016, Trace-element geochemical data from stream sediments collected in the Tok River area, Tanacross A-5 and A-6 quadrangles, Alaska in 2016: Alaska Division of Geological \& Geophysical Surveys Raw Data File 2016-10, 3 p. http://doi. org/10.14509/29688

Reioux, D.A., Werdon, M.B., Seitz, S.S., and Mulliken, K.M., 2016, Digital compilation of geochemical data for historical samples from occurrences of strategic and critical elements in Alaska: Part II - Platinum group elements (PGE): Alaska Division of Geological \& Geophysical Surveys Raw Data File 2016-12, 2 p. http://doi.org/10.14509/29474

Sicard, K.R., Naibert, T.J., Hubbard, T.D., Twelker, Evan, Wypych, Alicja, Werdon, M.B., Willingham, A.L., Gillis, R.J., Lande, L.L., and Newberry, R.J., 2017, Geologic map of the Tok River area, Tanacross A-5 and A-6 quadrangles, eastern Alaska Range, Alaska: Alaska Division of Geological \& Geophysical Surveys Preliminary Interpretive Report 2017-3, 15 p., 1 sheet, scale 1:63,360. http://doi.org/10.14509/29722

Todd, Erin, Kylander-Clark, Andrew, Wypych, Alicja, Twelker, Evan, and Sicard, K.R., 2017, U-Pb and Lu-Hf isotope, age, and trace-element data from zircons at four sites in the western Alaska Range and Talkeetna Mountains, Alaska: Alaska Division of Geological \& Geophysical Surveys Raw Data File 2017-2, 7 p. http://doi.org/10.14509/29717

Werdon, M.B., 2017, Alaska's mineral industry 2016: Mining, exploration and discoveries (presentation): Association for Mineral Exploration British Columbia Mineral Exploration Roundup, January 23-26, 2017: Alaska Division of Geological \& Geophysical Surveys, 34 p. http://doi.org/10.14509/29711

Wypych, Alicja, Sicard, K.R., Gillis, R.J., Lande, L.L., Naibert, T.J., Newberry, R.J., Twelker, Evan, Werdon, M.B., and Willingham, A.L., 2016, Major-oxide and trace-element geochemical data from rocks collected in the Tok River area, Tanacross A-5 and A-6 quadrangles, Alaska in 2016: Alaska Division of Geological \& Geophysical Surveys Raw Data File 2016-9, 3 p. http://doi. org/10.14509/29685 


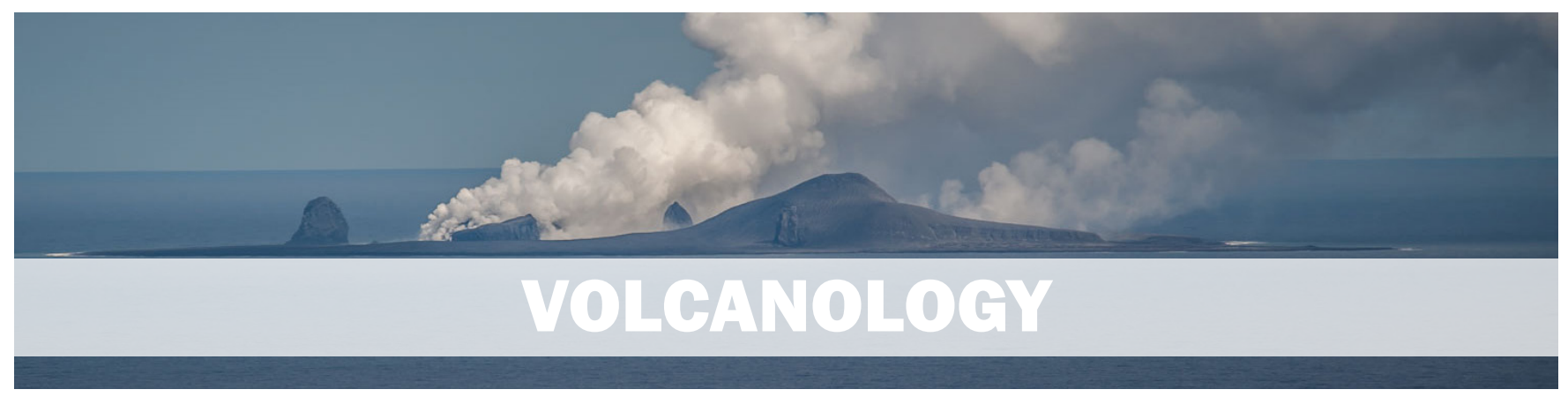

\section{BENEFIT TO ALASKA}

The DGGS Volcanology Section conducts geologic studies to improve our understanding of volcanic systems to better forecast future eruptions and to assess their potential impact to society.

\section{DGGS AND THE ALASKA VOLCANO OBSERVATORY}

There are 54 active volcanoes in Alaska and, on average, one or two of these volcanoes erupt each year. This year, Bogoslof and Cleveland volcanoes were the main players, spewing ash into the atmosphere from more than 60 explosive eruptions in the last 12 months. Ash in the atmosphere poses a significant threat to commercial air traffic over the
North Pacific and disrupts local air traffic based out of important economic hubs in the Aleutians such as Unalaska and the Port of Dutch Harbor. Daily, 50,000 people travel in air routes over Alaska volcanoes. As a partner in the interagency Alaska Volcano Observatory (AVO), Volcanology Section staff play a lead role in communication of volcanic unrest to the public by managing all web-based information, including a popular website and active Facebook and Twitter accounts. In addition, volcanology staff maintain an internal website and produce applications that allow AVO scientists to monitor volcanic activity remotely, manage internal communication and geophysical data streams, and efficiently respond to escalating volcanic unrest.

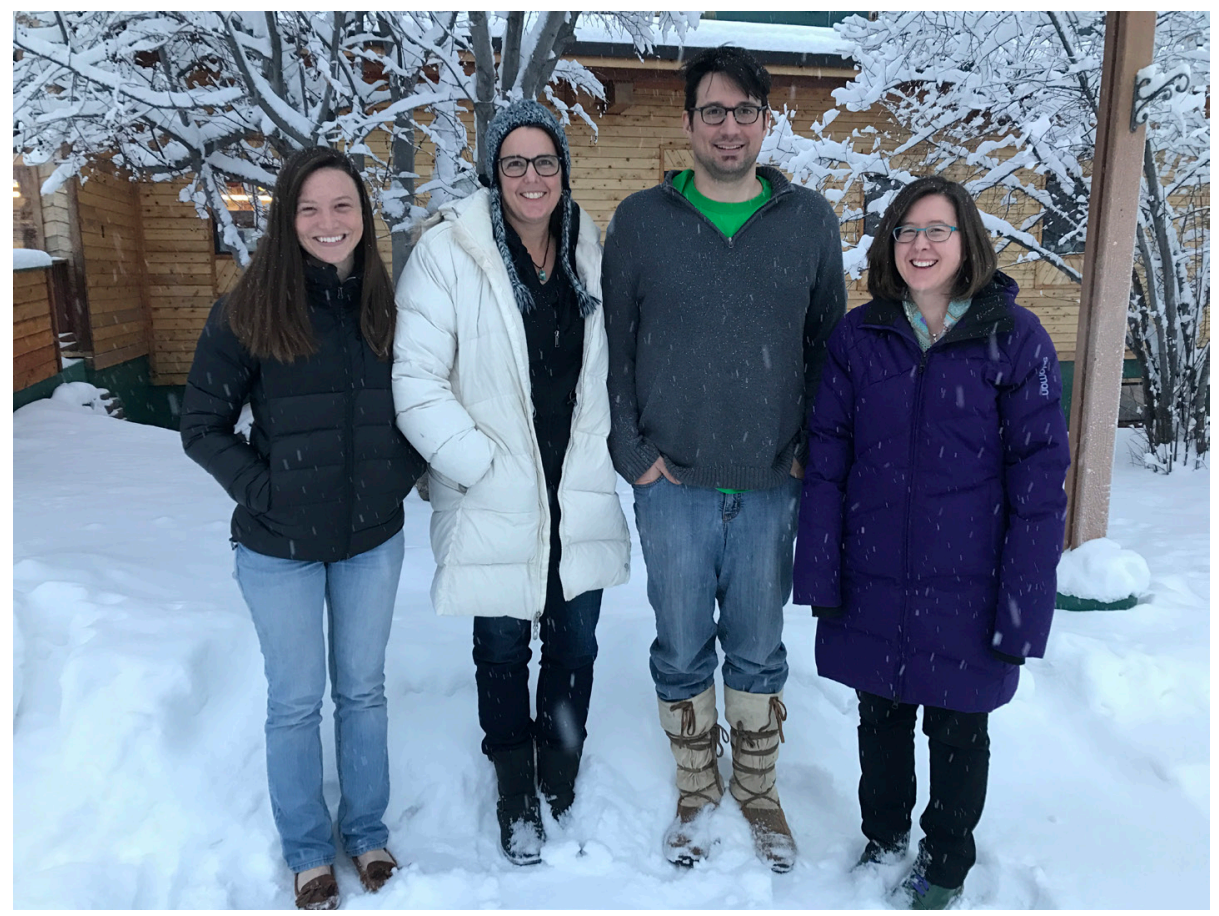

Katie Mulliken, Janet Schaefer, Scott Crass, Cheryl Cameron 


\section{REPONSE TO ERUPTIONS AT BOGOSLOF VOLCANO}

The continuing eruption of Bogoslof Volcano has consumed much of the Volcanology Section's staff time since it began erupting in December, 2016. DGGS-AVO staff participate in around-the-clock volcano monitoring of satellite and seismic data and work collaboratively with partners at the U.S. Geological Survey, the University of Alaska, Fairbanks, and the National Weather Service to assess activity level at the volcano, track ash cloud movement, and make informed decisions regarding aviation color code alerts and marine hazards. We keep detailed records of eruption timelines, pilot reports, and monitoring data, respond to media requests, and keep the public informed via the AVO public website, Facebook page, and Twitter. In response to the unrelenting eruptions at Bogoslof Volcano (over 60 explosive events since December, 2016), DGGS-AVO staff built a chat server to enable enhanced remote eruption response; the application of the chat server allowed for more efficient communication among AVO staff scientists, aiding in faster eruption response times and quicker deployment of alert level changes and warnings of ash fall.

Janet Schaefer, Volcanology Section Chief, and USGS/AVO colleague, Kristi Wallace, traveled to Unalaska/Dutch Harbor shortly after that community experienced an ash fall event from a Bogoslof eruption. Schaefer and Wallace gave two standing-room-only community ash fall preparedness presentations, two radio interviews with KUCB and one newspaper interview with the Bristol Bay Times/Dutch Harbor Fisherman, led seven 1-hour ash fall collection workshops at the local schools, and conducted fieldwork to collect ash samples and clear snow and ice off seismic and telemetry equipment. Each community presentation was accompanied by an engaging question and answer session. These presentations were attended by a broad cross section of the community, including Qawalangin Tribal Council members, public utility officials, fishermen, public health workers, and reporters. Schaefer and Wallace also installed an air quality instrument on the roof of the Unalaska Public Works building to assess community air quality during volcanic ash fall events. During the course of their 5-day visit to this community, Bogoslof erupted four times, sending ash 25,000 to 38,000 feet above sea level, including an event during the ash sampling fieldwork that caused Schaefer and Wallace to abort fieldwork and return to Dutch Harbor ahead of the advancing ash cloud.
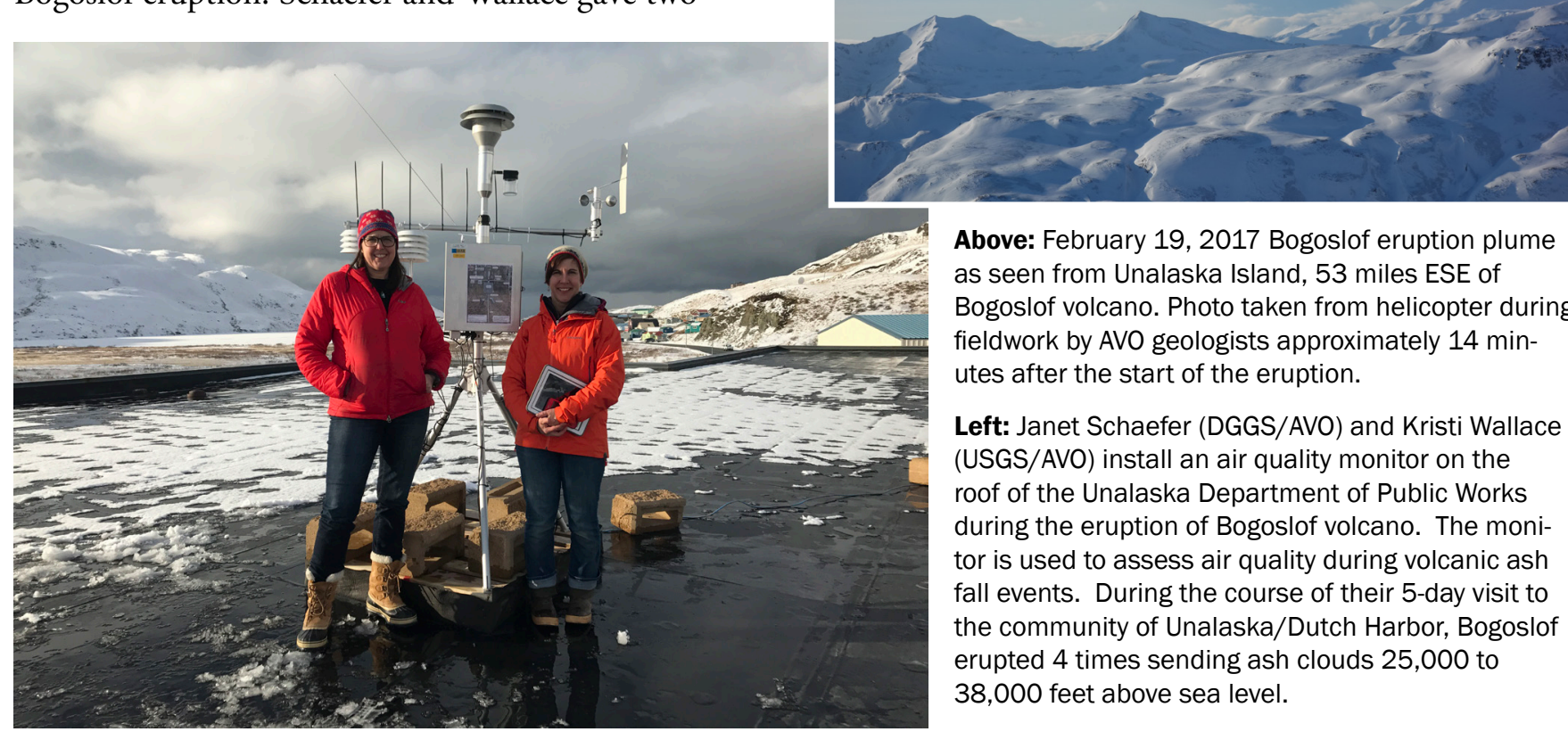

Above: February 19, 2017 Bogoslof eruption plume as seen from Unalaska Island, 53 miles ESE of Bogoslof volcano. Photo taken from helicopter during fieldwork by AVO geologists approximately $14 \mathrm{~min}$ utes after the start of the eruption.

Left: Janet Schaefer (DGGS/AVO) and Kristi Wallace (USGS/AVO) install an air quality monitor on the roof of the Unalaska Department of Public Works during the eruption of Bogoslof volcano. The monitor is used to assess air quality during volcanic ash fall events. During the course of their 5-day visit to the community of Unalaska/Dutch Harbor, Bogoslof erupted 4 times sending ash clouds 25,000 to 38,000 feet above sea level. 


\section{GeoDIVA - THE PRIMA DONNA OF VOLCANO DATABASES}

Volcanology Section staff design, populate, maintain, and distribute via the web the Geologic Database of Information on Volcanoes of Alaska (GeoDIVA). This data supports scientific investigation, crisis response, and is the heart of AVO's database-driven public website (avo.alaska.edu). GeoDIVA continues to be acknowledged as a worldwide standard of how volcano observatories should store critical information on volcanic activity. It is a robust database, housing large amounts of geological and geochemical data, along with images, a comprehensive bibliography, eruption chronologies, and satellite remote sensing observations. GeoDIVA houses more than 5,000 bibliographic references on Alaska volcanism. The image database has grown immensely and now contains more than 26,000 images, which are searchable, and tied to keywords, eruptions, samples, field stations, volcanoes, and more. The on-line, searchable geochemical database is a massive effort that grows annually as more data is published and now holds more than 9,000 whole rock and glass geochemical analyses; all published data are available to the public at avo.alaska.edu/ geochem. In an ongoing effort to better categorize seismic unrest and to improve eruption forecasting, AVO-DGGS designed and built a seismic observation database to compliment the currently operational remote sensing observation database. With the continued expansion and population of GeoDIVA, AVO staff are able to design queries to effectively evaluate relationships between observations of unrest and explosive activity, making continual progress toward the goal of forecasting eruptions.

\section{ASSESSING VOLCANIC ASH FALL HAZARDS}

The Alaska Tephra Database was developed to support Alaska Volcano Observatory (AVO) research of volcanologic processes and volcano-hazard studies and to benefit scientists from other disciplines who are interested in the identification and correlation of Holocene- or Pleistocene-aged tephra deposits. The Alaska Tephra Database links sample metadata, chemical analyses, age information, and eruption data, making it possible for researchers in many disciplines to efficiently query and download Alaska tephra data using an on-line data interface, scheduled to be made public in 2018. Currently, the database contains more than 8,000 tephra samples from Alaska and the Yukon Territory, Canada, roughly a third of which have associated glass geochemical data. The database will continue to grow as new data becomes available and, as the primary repository of Alaska tephra data, will be a valuable tool for multidisciplinary studies and volcanic eruption history and hazards research in Alaska.

A derivative product of the Alaska Tephra Database is a geospatial database of ash fall extents that capture areas of ash fall inundation that have occurred over the last $\sim 10,000$ years. An understanding of volcanic ash volumes and dispersion helps support our ongoing effort to assess volcanic ash fall hazards in the state by answering questions, such as how many times a community has received ash fall and what is a reasonable amount of ash fall to expect. Ash fall hazards information in the geospatial database includes ash fall extent, ash deposit thickness, age of ash fall, source volcano, deposit descriptions, and associated literature references.

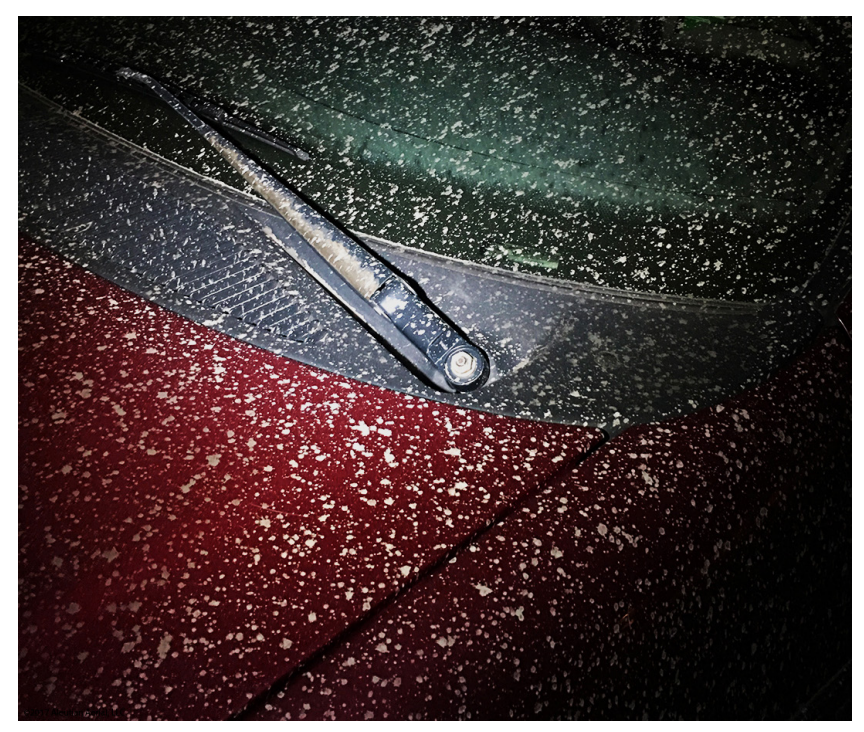

Above: Ash covers a car in Unalaska following the January 31, 2017 eruption of Bogoslof volcano. Volcanic ash consists of tiny jagged pieces of rock and glass making it hard and abrasive. Photo courtesy of Andy Dietrick. 


\section{GEOLOGIC MAPPING AND} VOLCANO HAZARD ASSESSMENT AT CHIGINAGAK, KASATOCHI, MAKUSHIN AND OKMOK VOLCANOES

Understanding the geologic history of volcanoes is one of the most important tools in volcano hazard and risk assessment. Without knowledge of a volcano's eruption history, including the frequency, magnitude, and style of past eruptions, it is difficult to constrain future eruptive capability. Volcano hazard and risk assessment requires detailed geologic mapping, including a well-constrained understanding of the geochronology, tephra stratigraphy, and geochemistry. Volcanology Section staff, along with colleagues from both the USGS and University of Alaska, Fairbanks (UAF), are advancing the understanding of volcanic processes and hazards with geologic mapping and geochemical and tephra studies at Chiginagak, Kasatochi, Shishaldin, Makushin, and Okmok volcanoes. Geologic information for Chiginagak, Okmok, Shishaldin, and Kasatochi has been compiled into the National Cooperative Geologic Mapping Program geospatial database format. A geologic map, report, and geodatabase for both Kasatochi and Chiginagak volcanoes were published this year, with data files including mapped units, whole rock geochemistry, and ${ }^{40} \mathrm{Ar} /{ }^{39} \mathrm{Ar}$ geochronology results. At Makushin volcano, a stratigraphic framework of Holocene ash fall has been completed, including geochronology and glass chemistry analyses. Field investigations have revealed multiple ash fall events which have impacted Dutch Harbor. Knowing the frequency and magnitude of these ash fall events is critical in understanding ash fall hazard risk assessment of the region.

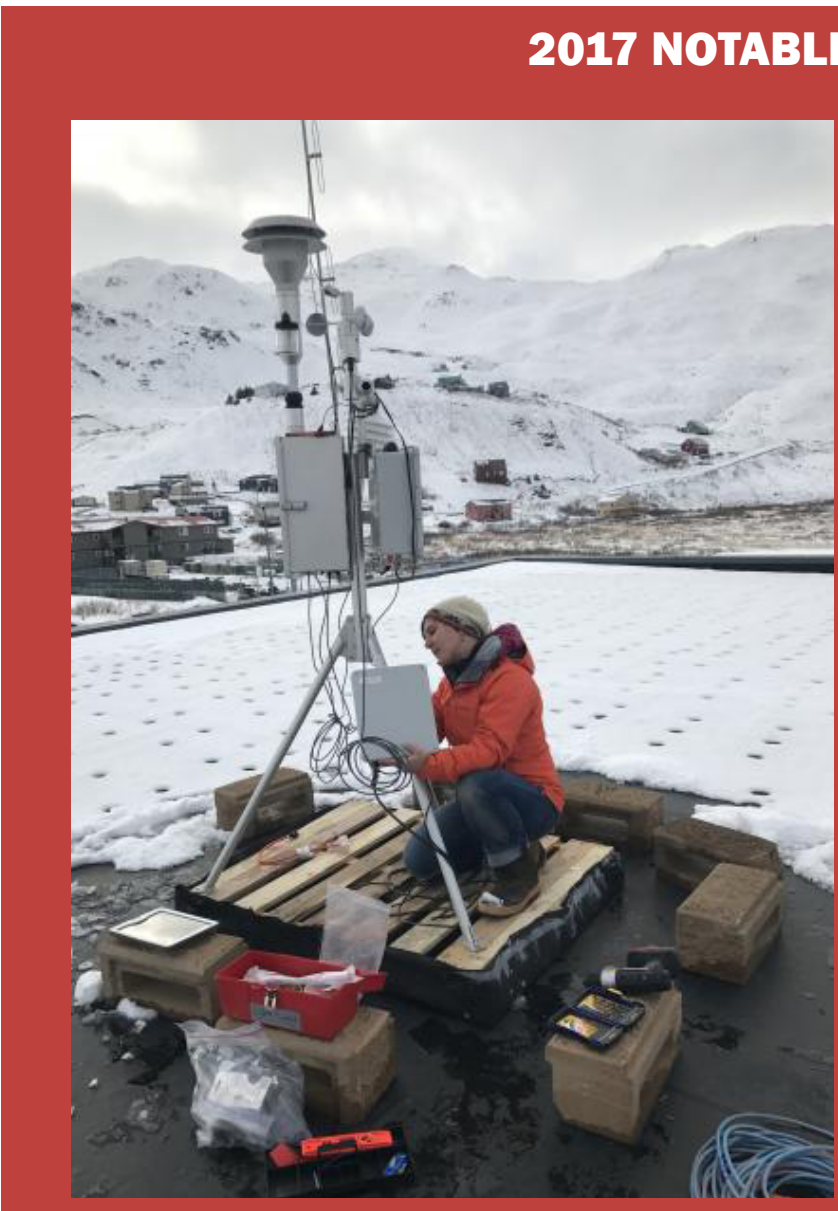

- Analyzed AVO's volcanic activity notifications and alerts through time, eruptions, and unrest periods to determine AVO's alert effectiveness and to seek improvement in our messaging. Results will be published in an on-line, scientific journal.

- Helicopter procurement and fuel logistics support for all AVO field projects including geophysical monitoring station maintenance, geologic field investigations, and eruption response.

- Authored AVO's 2014 and 2015 annual summary of volcanic activity. These annual summaries volcanic activity in Alaska have been published every year since 1993, and DGGS Volcanology staff (Cameron) is now taking the lead role in their authorship, where it had been previously assigned to USGS/AVO staff.

Kristi Wallace (AVO/USGS) installs an air quality monitor in Unalaska to record ash fall impacts during the eruption of Bogoslof volcano. Photo by Janet Schaefer. 


\section{VOLCANOLOGY 2017 PUBLICATIONS}

Cameron, C.E., Dixon, J.P., Neal, C.A., Waythomas, C.F., Schaefer, J.R., and McGimsey, R.G., 2017, 2014 Volcanic activity in Alaska - Summary of events and response of the Alaska Volcano Observatory: U.S. Geological Survey Scientific Investigations Report 2017-5077, 81 p., https:// doi.org/10.3133/sir20175077

Dixon, J.P., Cameron, C.E., Iezzi, A.M., and Wallace, Kristi, 2017, 2015 Volcanic activity in AlaskaSummary of events and response of the Alaska Volcano Observatory: U.S. Geological Survey Scientific Investigations Report 2017-5104, 61 p., https://doi.org/10.3133/sir20175104

Mulliken, K.M., Cameron, C.E., Crass, S.W., Schaefer, J.R., and Wallace, K.L., 2017, An update on the Alaska Tephra Database (poster): International Association of Volcanology and Chemistry of the Earth's Interior (IAVCEI) 2017 Scientific Assembly, November 14-18, 2017: Alaska Division of Geological \& Geophysical Surveys, 1 sheet. http://doi.org/10.14509/29746 Nye, Chris, 2017, Kasatochi Island 2009 topography: Alaska Division of Geological \& Geophysical
Surveys Miscellaneous Publication 163, 1 sheet, scale 1:10,000. http://doi.org/10.14509/29733 Nye, C.J., Scott, W.E., Neill, O.K., Waythomas, C.F., Cameron, C.E., and Calvert, A.T., 2017, Geology of Kasatochi volcano, Aleutian Islands, Alaska: Alaska Division of Geological \& Geophysical Surveys Professional Report 123, 127 p., 1 sheet, scale 1:5000. http://doi. org/10.14509/29718

Schaefer, Janet R., Scott, William E., and Layer, Paul W., 2017, Geologic map of Mount Chiginagak Volcano, Alaska: Alaska Division of Geological \& Geophysical Surveys Report of Investigations 2017-10, 32 p., 1 sheet, scale 1:63,360.

Schaefer, J.R., Mulliken, K.M., Cameron, C.E., and Wallace, K.L., 2017, Digitizing Alaska’s ashfall record: a tephra geospatial database (poster): International Association of Volcanology and Chemistry of the Earth's Interior (IAVCEI) 2017 Scientific Assembly, November 14-18, 2017: Alaska Division of Geological \& Geophysical Surveys, 1 sheet. http://doi.org/10.14509/29747 


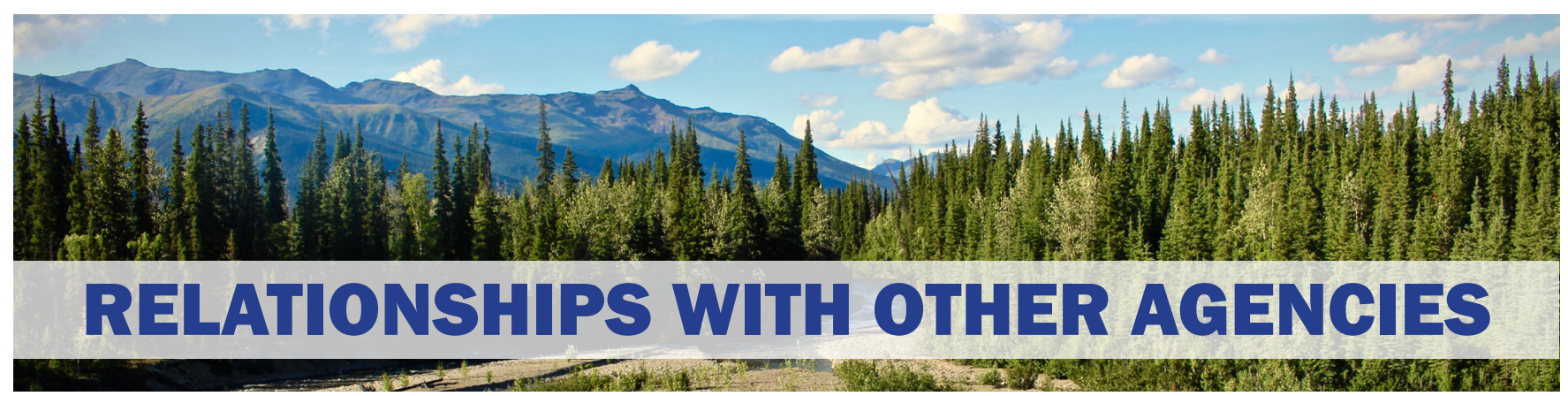

DGGS develops its strategic programs and project schedule through consultation with the many users of geologic information: state and federal agencies, the Alaska Legislature, the federal congressional delegation, professionals in the private sector, academia, and individual Alaskans. Their input to DGGS programs comes through the Alaska Geologic Mapping Advisory Board, liaison activities of the Director, and personal contact between DGGS staff and the groups listed above.

\section{STATE AGENCIES}

DGGS provides other Department of Natural Resources (DNR) and state agencies with routine analyses and reviews of various geologic issues such as geologic hazards; evaluations of pending oil and gas lease tracts; area plans; competitive coal leases; geologic assessments of land trades, sales, selections, or relinquishments; oil and gas and mineral potential; and construction materials availability.

\section{Each year DGGS works closely with:}

- DNR Division of Oil \& Gas (DOG) on issues related to energy resources, and in providing geologic control for the subsurface oil-related geologic analyses conducted by DOG;

- DNR Office of Project Management and Permitting (OPMP), with technical expertise during large project permitting;

- Division of Economic Development in the Department of Commerce, Community, and Economic Development (DCCED), to report on the status of Alaska's mineral industry;

- Division of Homeland Security \& Emergency Management (DHSEM; in the Department of Military and Veterans Affairs [DMVA]), and the Department of Environmental Conservation (DEC) to evaluate volcanic and other hazards, develop scenarios for hazards events, and update the State Hazard Mitigation Plan;

- Department of Transportation \& Public Facilities (DOT\&PF), University of Alaska Fairbanks (UAF), and other agencies to assess the impacts of landslides, slope failures, avalanches, flooding, erosion, and construction materials availability;

- Alaska Energy Authority (AEA) to evaluate hazards to proposed hydroelectric, geothermal, and other energy projects; to provide technical expertise on geothermal resource potential, and; to evaluate resource potential around the state that might provide viable alternatives for energy development in rural Alaska;

- DNR Division of Mining, Land, and Water (DMLW) to evaluate groundwater issues and address land selection and sale questions;

In recent years with the Alaska Natural Gas Pipeline project, Alaska Gasline Development Corporation (AGDC), and the State Pipeline Coordinator to assist in geologic data collection and hazards assessment for proposed natural gas pipelines.

Large inter-division or other one-time efforts responding to special needs are generally supported by interagency fund transfers. Smaller requests are funded by DGGS's annual general fund appropriation.

\section{LOCAL GOVERNMENTS}

Many of the cooperative efforts implemented by DGGS with borough and municipal governments are conducted on a mutually beneficial, but informal basis. For example, DGGS participates in a federally-funded cooperative program to develop tsunami-inundation maps for coastal communities. In communities for which inundation maps have been prepared in recent years, DGGS works closely with collaborators and city and borough governments to design project outputs to 
meet community needs for planning evacuation areas and routes.

DGGS works closely with local communities to help assess hazards and alternatives for mitigating the effects of erosion, flooding, and other surface processes that threaten their sustainability. DGGS also sends personnel to respond to natural disasters, such as the Sitka landslides in September 2015. Similarly, DGGS works with rural communities to help assess potential local energy resources as alternatives to diesel fuel. During volcanic unrest and eruption, DGGS, as a partner in the Alaska Volcano Observatory, communicates with local villages, industry sectors, the aviation community, and the military to share information and observations of volcanic unrest.

\section{THE UNIVERSITY OF ALASKA}

DGGS has a longstanding and productive professional association with geoscientists and students at the University of Alaska. University of Alaska faculty often work as DGGS project team members on a wide range of collaborative research projects. University student interns are also an important part of the DGGS workforce; while working on DGGS projects, students learn a wide variety of geology-related skills. Some graduate students are able to apply their DGGS intern work to their thesis projects through research programs established through a Memoranda of Agreement with the University of Alaska, Fairbanks (UAF) Department of Geology \& Geophysics and Department of Mining \& Geological Engineering. DGGS and the university make frequent use of each other's libraries and equipment and University of Alaska faculty and students also frequent the Geologic Materials Center in Anchorage, where faculty conduct core logging classes. DGGS' Volcanology Section has a long-term cooperative relationship with the UAF Geophysical Institute, resulting from partnership in the Alaska Volcano Observatory.

\section{FEDERAL AGENCIES}

DGGS has cooperative programs with numerous federal agencies including the U.S. Geological Survey (USGS), National Oceanic and Atmospheric Administration (NOAA), U.S. Fish and Wildlife Service (FWS), National Aeronautics and Space Administration (NASA), National Science Foundation (NSF), and periodically with the Federal Emergency Management Agency (FEMA), U.S. Department of Housing and
Urban Development (HUD), the U.S. Bureau of Land Management (BLM) and the U.S. Department of Energy (DOE). In the past, DGGS has also engaged in cooperative programs with the U.S. Minerals Management Service (MMS), now the Bureau of Ocean Energy Management.

DGGS receives federal funds from matching grants for which the division must compete nationally with other organizations on a yearly basis. DGGS has been successful in securing federal funds to support mineral inventory mapping, surficial and earthquake hazards-related mapping, geologic-hazards evaluations, and studies related to oil and gas and geothermal potential. Although DGGS has historically been very successful in receiving federal grants and appropriations, the process is competitive and these funds are therefore project-specific or complementary to statefunded programs and do not replace state general fund support. Federal funding is pursued only for projects that advance and serve the division's statutory mission.

Two ongoing cooperative federal programs have provided support for key elements of the DGGS mission for many years. One is the Alaska Volcano Observatory (AVO), a partnership established in 1988 consisting of USGS, DGGS, and the UAF Geophysical Institute. The USGS funds and administers the program for the purpose of providing a coordinated approach to mitigating volcano-hazard risks to the public, state infrastructure, and air commerce. The second ongoing program is the STATEMAP component of the National Cooperative Geologic Mapping Program, established by Congress in 1992 and administered by the USGS. STATEMAP provides matching funds for geologic mapping projects according to priorities set by the Alaska Geologic Mapping Advisory Board (GMAB; see below).

DGGS has been successful in receiving cooperative agreements from the National Geological \& Geophysical Data Preservation Program (NGGDPP) and the National Cooperative Geologic Mapping Program (NCGMP). The NGGDPP, funded by the USGS, has supported several DGGS projects to preserve and make geologic information publicly available. STATEMAP funds provide a stable source of federal funding for geologic mapping in the state. 


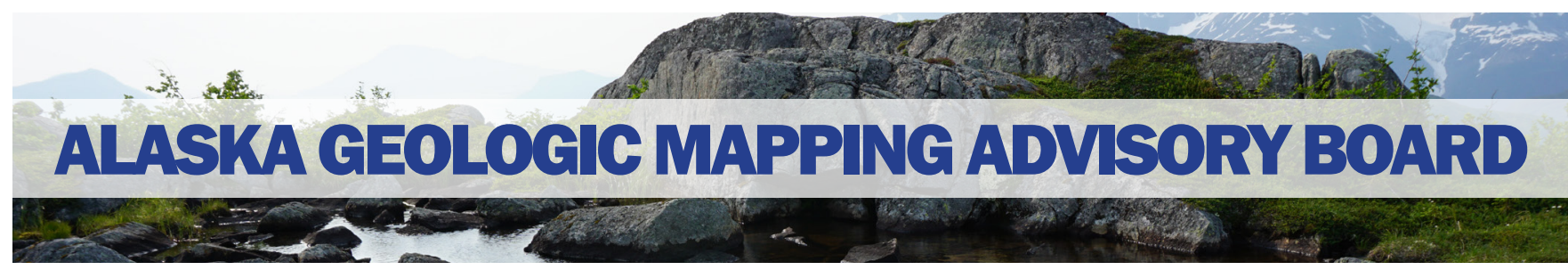

The Alaska Geologic Mapping Advisory Board (GMAB) guides DGGS in pursuing its goal of providing earth science information to the Alaska public. A number of prominent geologists and community leaders, with a variety of backgrounds and a broad spectrum of experience in Alaska, have agreed to serve on the advisory board. The board held its first meeting in Fairbanks on October 22, 1995, and normally meets three times a year to discuss state needs, review DGGS programs, solicit and welcome comments and suggestions from the public, and provide recommendations to the state geologist.

This year, DGGS welcomed Ethan Schutt of Cook Inlet Region, Inc to the board. Mr. Schutt, is from Tok Alaska, became general counsel for CIRI in 2005 as was previously general counsel for Tanana Chiefs Conference in Fairbanks. He earned a bachelor's degree from Washington State University in 1995 and a juris doctor from Stanford University in 1999.

\section{Current members of the board are:} Steve Adamczak

Vice President, Shannon and Wilson, Inc. Mr. Adamczak has more than 30 years of experience in geotechnical engineering, and represents the engineering geology and geotechnical community.

\section{Margaret Darrow}

Chair of the University of Alaska Fairbanks, Department of Mining and Geological Engineering. Dr. Darrow has a background in

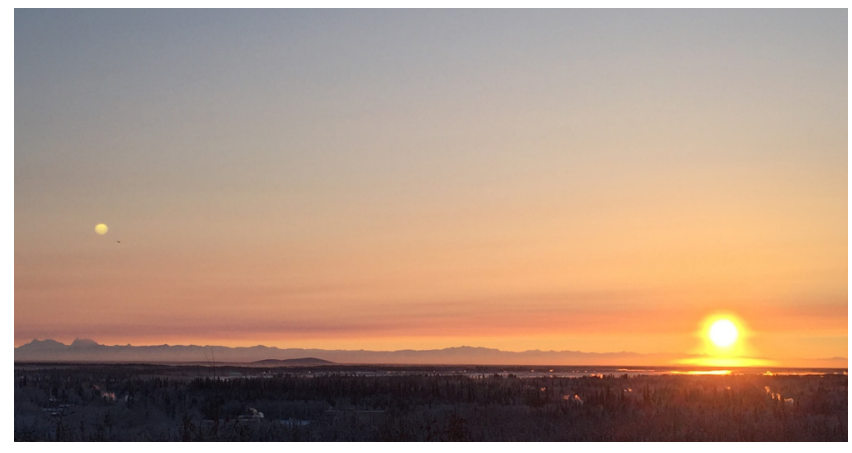

engineering geology with, and represents the University, the Department and also the engineering geology discipline.

\section{Curt Freeman, Chair}

President, Avalon Development Corporation. Mr. Freeman runs a well-known and successful consulting mineral exploration firm in Fairbanks and represents minerals industry interests.

\section{Tom Homza}

Principal Regional Geologist, Shell Exploration and Production, Alaska. Dr. Homza has 20 years oil and gas exploration experience and represents petroleum industry interests.

\section{James Jones}

U.S. Geological Survey. Dr. Jones specializes in tectonic evolution and mineral resources with the USGS Anchorage office, and represents the Federal government, earthquake hazards, and mapping interests.

\section{Anupma Prakash}

Co-Chair of the University of Alaska Fairbanks, Department of Geology and Geophysics. Dr. Prakash has a background in remote sensing in the Arctic, and represents the University and remote sensing and mapping interests.

\section{Ethan Schutt}

\section{Senior Vice President, Land and Energy}

Development, Cook Inlet Region Inc. Mr. Schutt oversees CIRI's land and energy development departments including the exploration and leasing of lands. He also directs CIRI's efforts in developing renewable and alternative energy projects. $\mathrm{He}$ represents energy resources, land management, and Alaska Native interests.

\section{Gregory Wilson}

Director Arctic Exploration and Services, ConocoPhillips Alaska. Dr. Wilson has more than 25 years of oil and gas exploration experience in Alaska and also represents the oil and gas industry. 


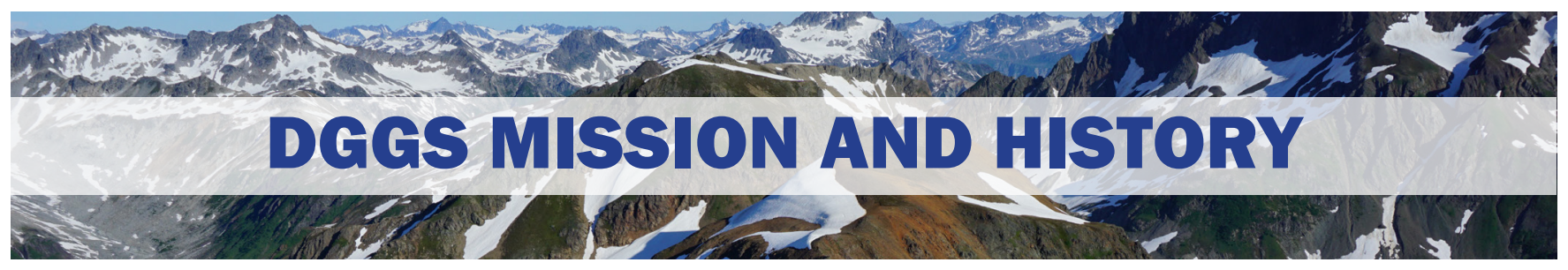

\section{MISSION STATEMENTS}

Department of Natural Resources: Develop, conserve, and enhance natural resources for present and future Alaskans

Division of Geological \& Geophysical Surveys: Determine the potential of Alaskan land for production of metals, minerals, fuels, and geothermal resources, the locations and supplies of groundwater and construction material; and the potential geologic hazards to buildings, roads, bridges, and other installations and structures (AS 41.08.020)

\section{HISTORY}

The present Division of Geological \& Geophysical Surveys (DGGS) evolved from Alaska’s Territorial Department of Mines. That heritage is reflected in the Division's ongoing commitment to the application of geology to improve the welfare of Alaska citizens. The current name and mission of the Division were established in 1972 with the passage of Alaska Statute AS 41.08.

- Territorial Department of Mines, prior to 1959

- Division of Mines and Minerals, 1959-1966

- Division of Mines and Geology, 1966-1970

- Division of Geological Survey, 1970-1972

- Division of Geological \& Geophysical Surveys, 1972-Present

\section{LEADERSHIP}

Eleven qualified professional geoscientists have served as State Geologist:

- Jim Williams, 1959-1971

- William Fackler, 1971-1973

- Donald Hartman, 1973-1975

- Ross G. Schaff, 1975-1986

- Robert B. Forbes, 1987-1990

- Thomas E. Smith, 1991-1995

- Milton A. Wiltse, 1995-2002

- Rodney A. Combellick (Acting), 2003-January 2005

- Mark D. Myers, February-October 2005

- Robert F. Swenson, November 2005-November 2013

- Steven S. Masterman, November 2013-present

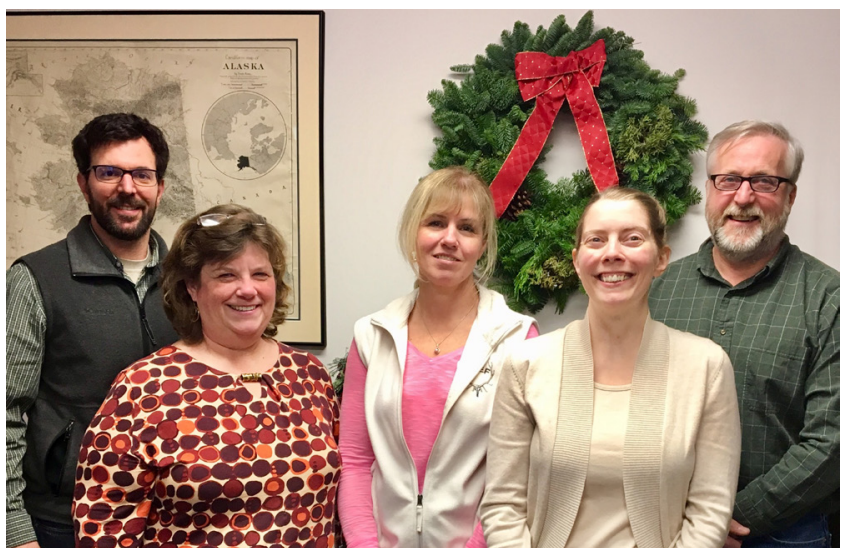

Ken Papp, Shelly Showalter, Linda Natrop, April Woolery, Steve Masterman

By statute the State Geologist serves as the Director of the Division of Geological \& Geophysical Surveys in the Department of Natural Resources (DNR) and is appointed by the DNR Commissioner. Since the early 1970s, State Geologists have been selected from lists of candidates prepared by the geologic community and professional societies in Alaska. A department order in 2002 formalized a process whereby the Geologic Mapping Advisory Board oversees evaluation of candidates and provides a list to the Commissioner. The qualifications and responsibilities of the State Geologist and the mission of DGGS are defined by statute.

\section{ORGANIZATION}

DGGS is one of seven divisions and six offices in the State of Alaska Department of Natural Resources. Under the overall administration of the Director's Office, the Division of Geological \& Geophysical Surveys is organized into five sections and the Geologic Materials Center (see organizational chart). The Division also administers the 11-member Alaska Seismic Hazards Safety Commission.

Current DGGS staff totals 36 permanent fulltime professional and support positions, 1 permanent part time position, with additional nonpermanent staff, and student interns. 


\section{PERFORMANCE MEASURES}
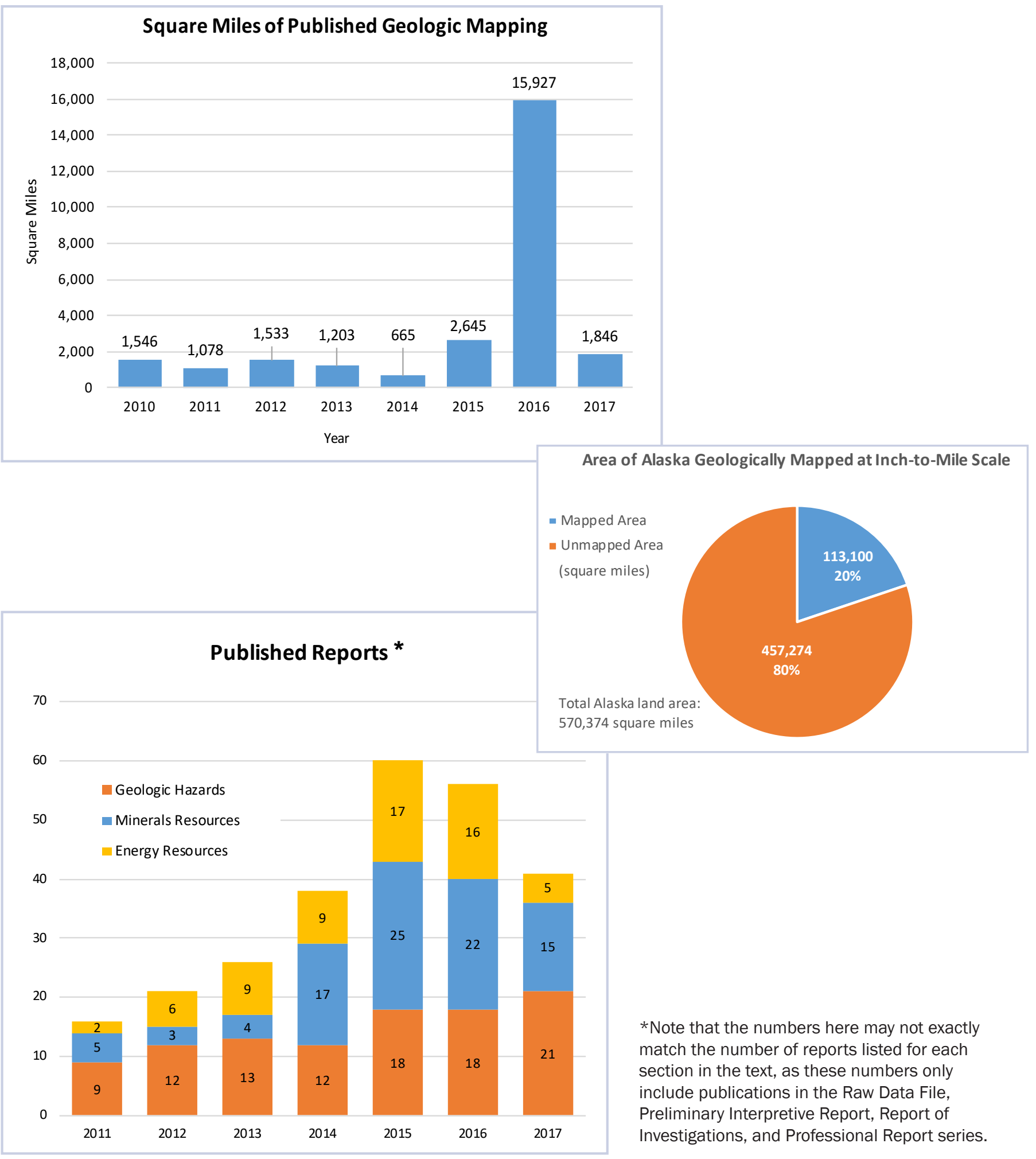

* Note that the numbers here may not exactly match the number of reports listed for each section in the text, as these numbers only include publications in the Raw Data File, Preliminary Interpretive Report, Report of Investigations, and Professional Report series. 

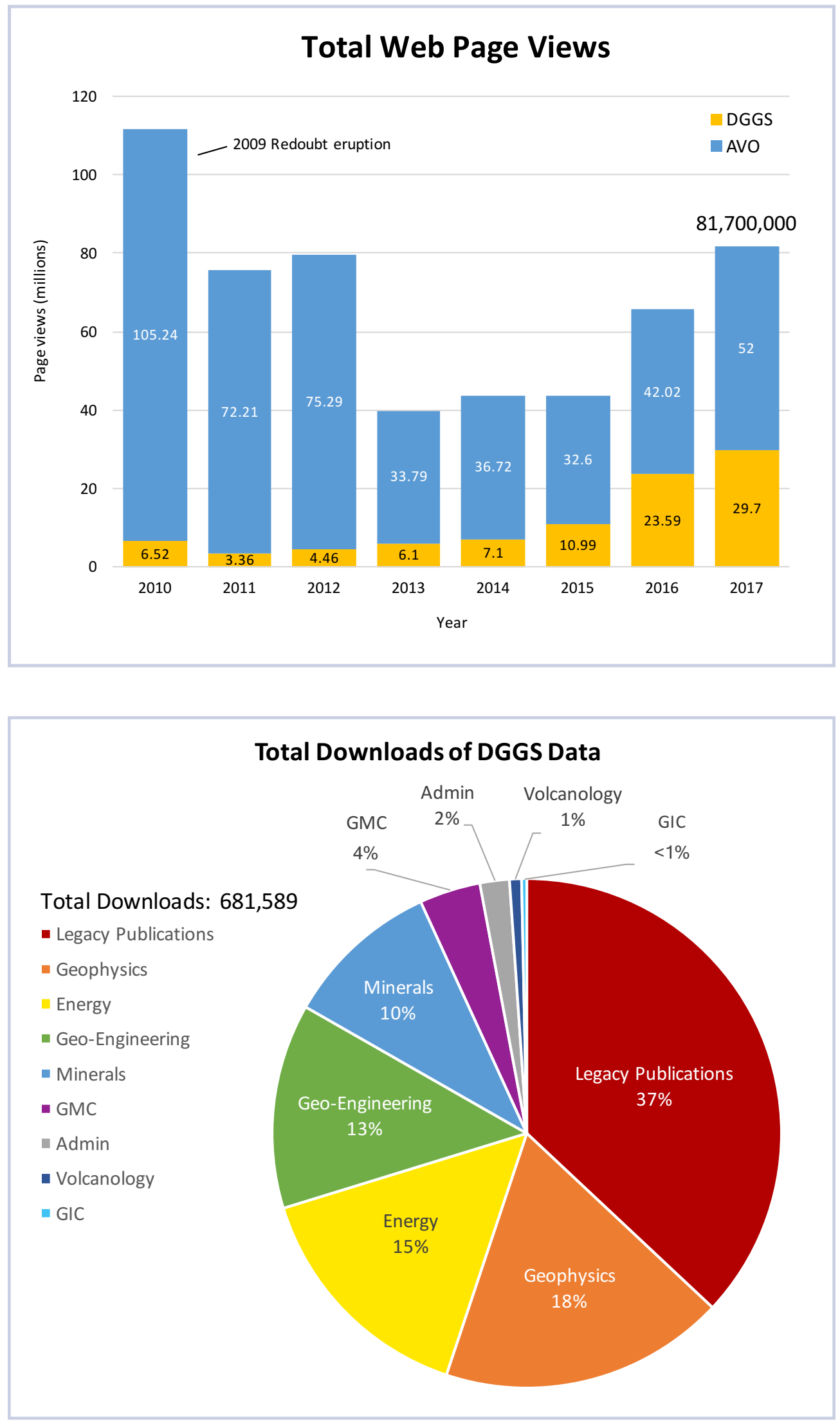

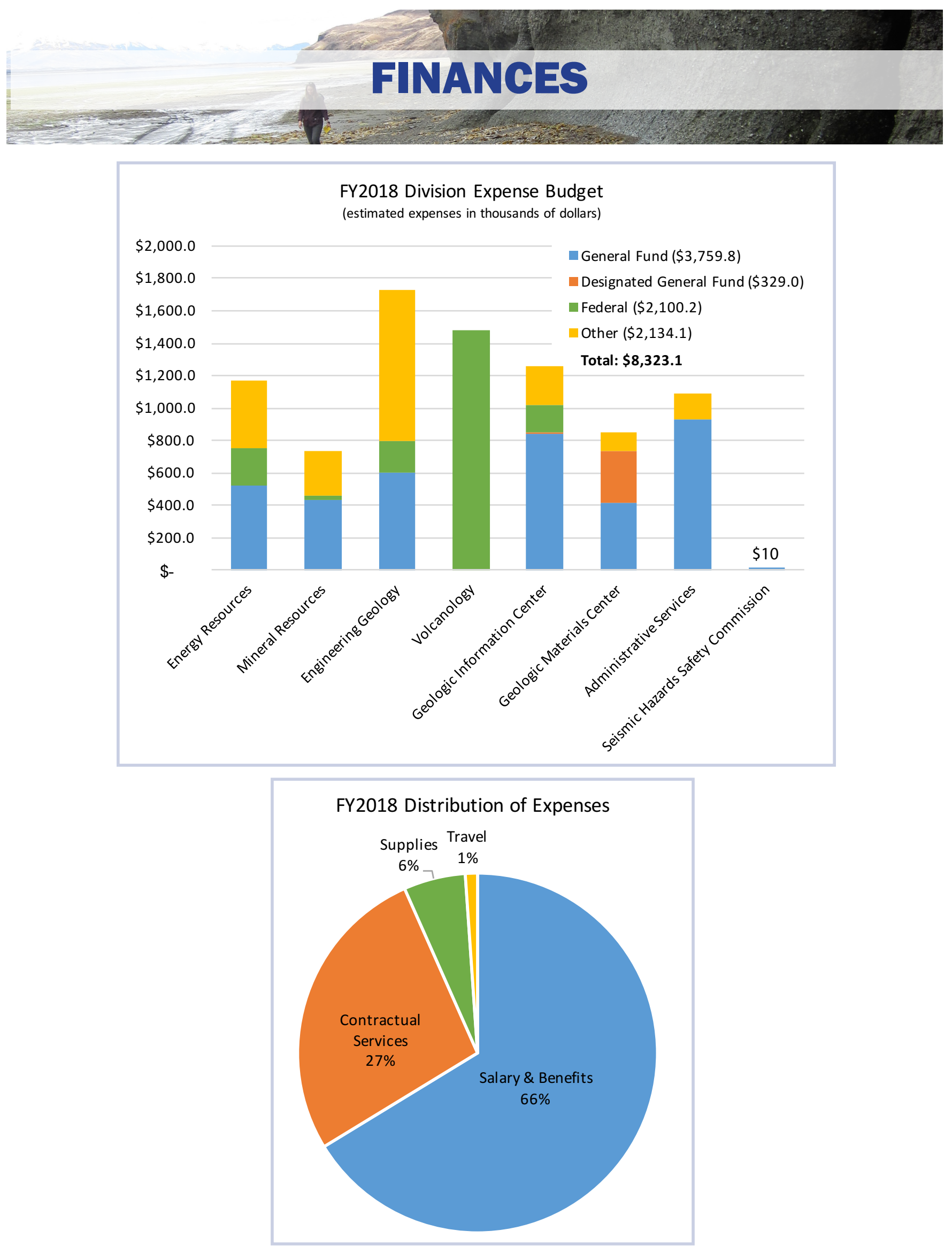

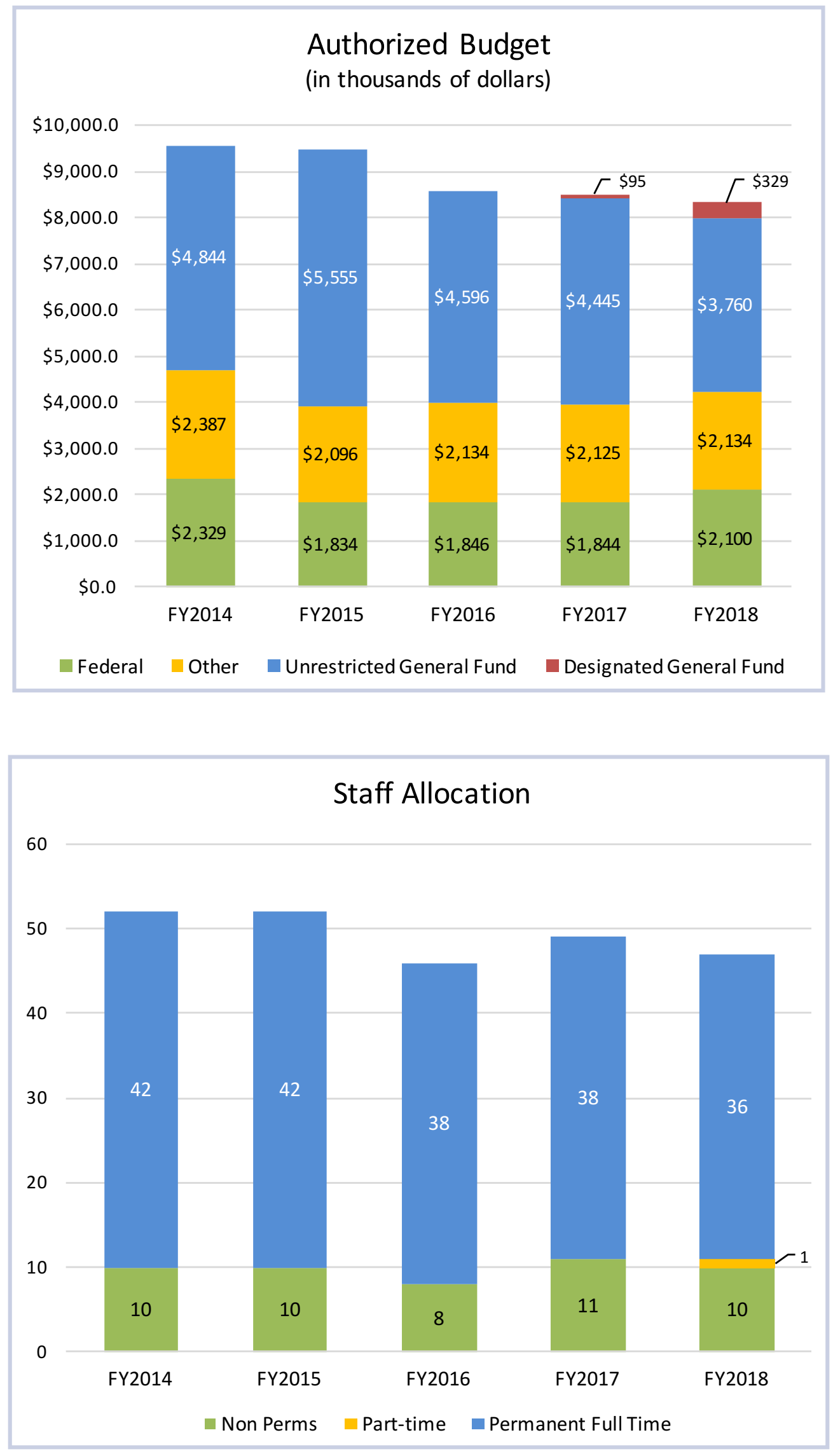


\section{WELCOME, NEW EMPLOYEES}

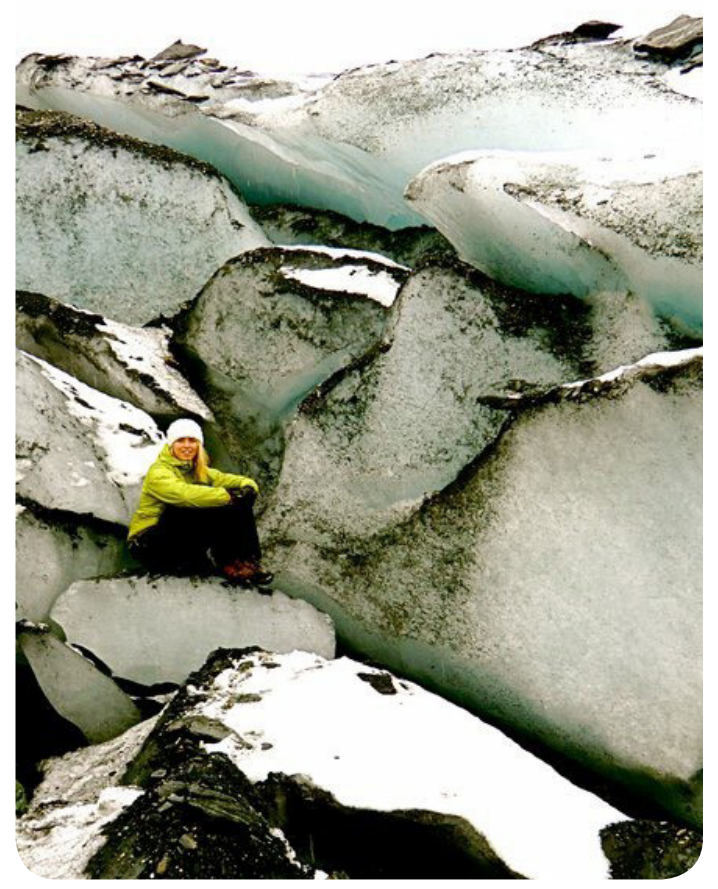

\section{Katreen Wikstrom Jones}

Katreen joined DGGS in January 2017 as a Geologist I for the Climate \& Cryosphere Hazards Program (CCHP) in the Engineering Geology Section. Originally from Sweden, she first came to Alaska in 2010, as an exchange student at the University of Alaska, Fairbanks. She fell in love with Alaska's rugged, vast landscape and the endless opportunities for backcountry recreation, as well as the research demand for studying its complex alpine terrain. Katreen earned a M.S. in Environmental Science at Alaska Pacific University in 2016. Her research background is focused on investigating snow avalanche release and flow behavior via the implementation of various remote sensing techniques and dynamical modelling. Before starting at DGGS, she worked as an Environmental Specialist/GIS technician in Anchorage, Alaska. She is excited to be an integral part of the CCHP, where she develops and analyzes high quality geospatial products for Alaska sites which are particularly prone to alpine natural hazards and where communities and infrastructure are potentially endangered.

\section{Katherine (Katie) Mulliken}

Katie has been with DGGS in a long-term, non-permanent position for the last year and recently started in a permanent Geologist I position with the Volcanology Section and interagency Alaska Volcano Observatory (AVO). She grew up in Volcano Village on the Big Island of Hawai' $i$ and after double majoring in Geology and Anthropology at the University of Hawai' $i$ at Hilo, moved to Fairbanks to get a master's degree at the University of Alaska, Fairbanks. During her graduate studies, Katie investigated the origin of volcanic ash deposits at archaeological sites in the Susitna River Valley, Alaska, and considered how the deposits may have impacted prehistoric hunter-gatherers

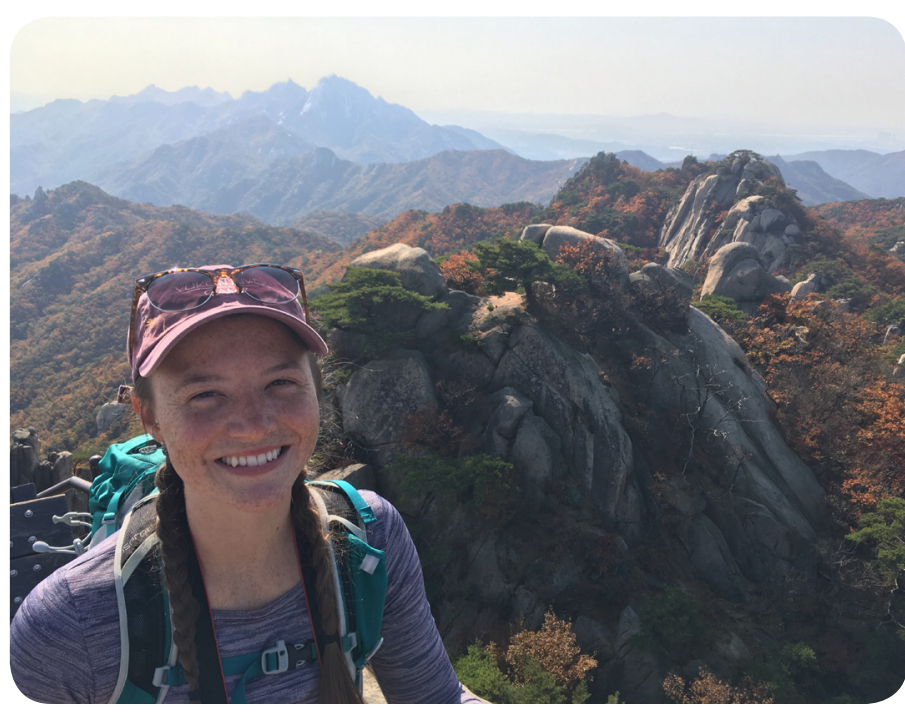
and their resources. Before working with DGGS, Katie worked for the Center for the Environmental Management of Military Lands as a field archaeologist, and she has excavated at numerous sites in interior Alaska, including the Upward Sun River and Delta River Overlook sites. In her work at DGGS, Katie will continue to help populate and maintain the Geologic Database of Information on Volcanoes in Alaska (GeoDIVA) and further Alaska ash fall studies. 


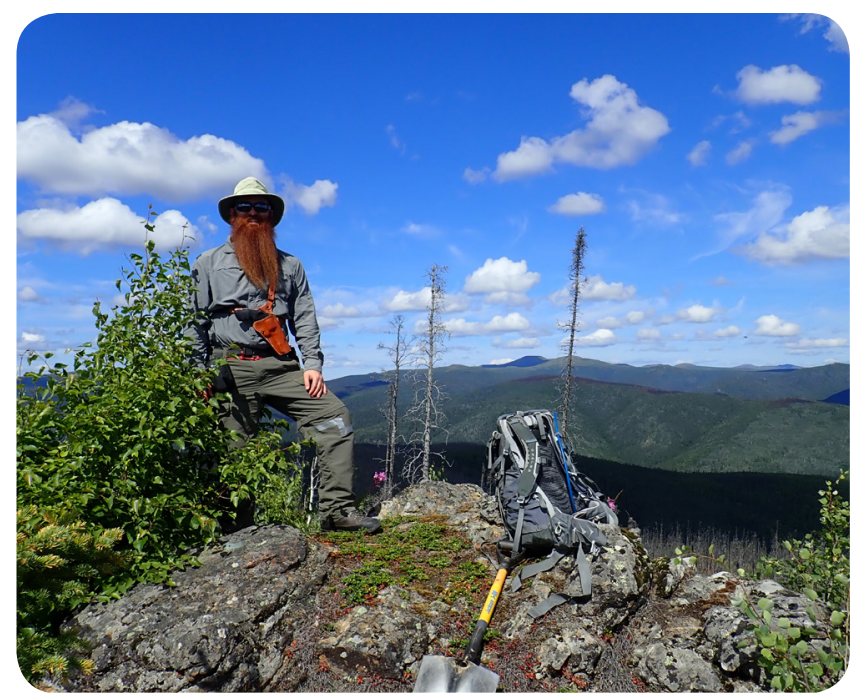

\section{J. Barrett Salisbury}

Barrett joined DGGS in early 2017 as a Geologist IV, specializing in earthquake geology for the Engineering Geology Section. He earned a B.S. in Geological Sciences with a focus on fluvial geomorphology from Washington \& Lee University in 2007. His interest in earthquakes and active faults drew him to California where he earned a M.S. in Geological Sciences at San Diego State University in 2010, followed by a Ph.D. in Geological Sciences at Arizona State University in 2016. His research focuses on integrating aspects of earthquake geology and paleoseismology using high-resolution topographic analyses and dating techniques (e.g., OSL, ${ }^{14} \mathrm{C}$ ) to understand the geomorphic evolution of active faults and characterize their activity. Barrett has worked on paleoseismology projects around the world, including Mexico, Panama, China, and Israel, and is now the seniorlevel scientific and operational leader for the division's neotectonics and active faulting research program.

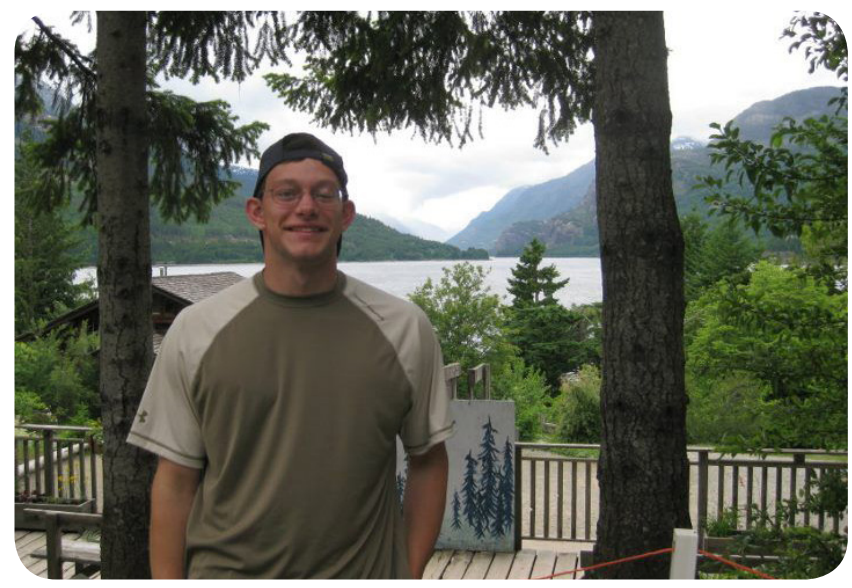

\section{Kristen Hendricks}

Kristen, who came to Fairbanks from New York in 2015, was hired as the survey's Publications Specialist in early 2017, and helps design and coordinate the division's publications queue. Her experience in communications, marketing, and design was a great fit at DGGS, as the survey continues to strongly emphasize educational and community outreach and produces an average of 35 publications a year. Prior to her new role at DGGS, Kristen was Communications Coordinator at the Northern Alaska Environmental Center, where she mastered the intricate stages of campaign organizing and community building while producing the content for all communication functions, including graphic design, social media, and social media platforms. Kristen graduated from the Rochester Institute of Technology, where she studied Medical Illustration, with high honors. She continues to put her background in fine art and illustration to good use. Since moving to Fairbanks she's also taken up several outdoor pursuits, especially skiing, and, to the bewilderment of her friends back in New York, considers winter her favorite time of year.

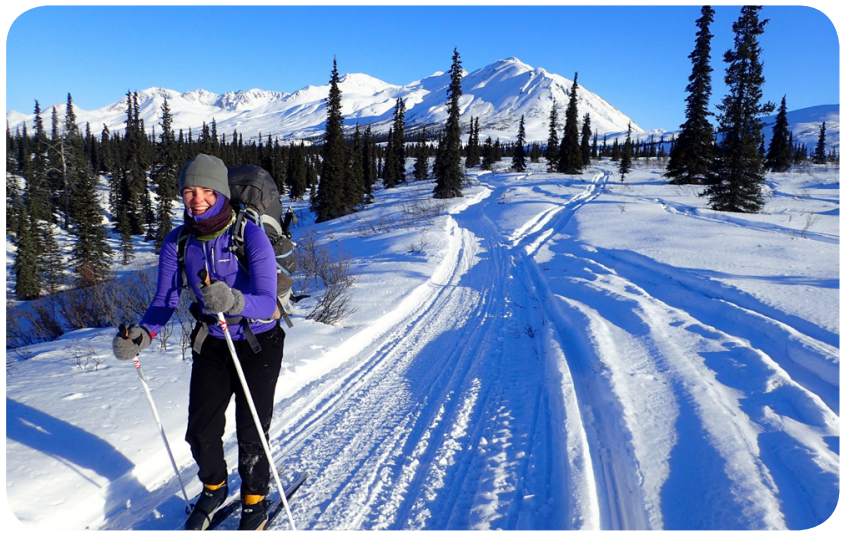

\section{Tom Cerny}

Tom recently graduated with a bachelor's degree in computer science from UAF and gained pertinent experience as a field technician for GCI and a student support technician at the UAF Office of Information Technology. As DGGS’ new, part-time Microcomputer/Network Technician, Tom rolls up his sleeves each day and quickly solves computer and software issues for everyone at the division, often with a smile. Tom is a lifelong Fairbanksan and we are grateful for his skills, experience, and infectious positive attitude. 


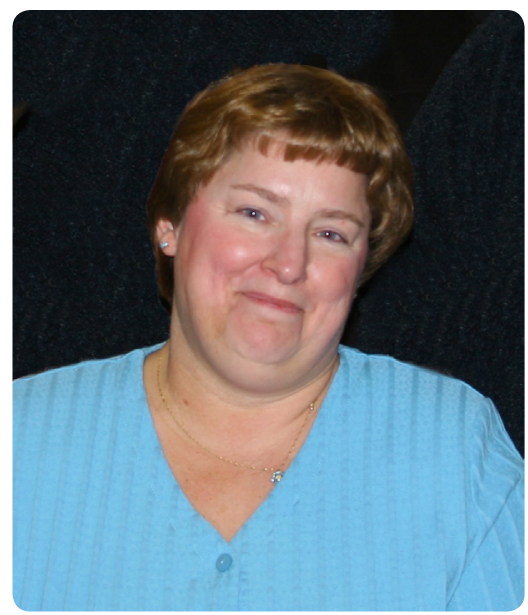

\section{Paula Davis}

Paula Davis began her employment with DGGS in March 1987 as a Clerk Typist III. She moved down the hall shortly thereafter to work as Secretary for DGGS's then-newly-arrived Director, Bob Forbes, who chose to be stationed in Fairbanks rather than Anchorage. After being appointed to be the division's Administrative Assistant, she was hired into an Administrative Manager position, in charge of compiling, submitting, and administering the budget, tracking grants and contracts, and managing the details associated with running a division.

In 1994, she moved out of the administrative realm and into a Publications Specialist position, becoming the lead editor for all of the division's reports, maps, and metadata for publication and online distribution. Paula enjoyed the challenge of learning a totally foreign vocabulary (i.e. geology and its sub-disciplines) and working alongside many geoscientists in this little corner of Alaska. A few years later, she was wisely chosen to be the section chief of the IT and publications section within the division.

Paula was our "DGGS Mom;" a warm, caring, nonjudgmental sounding board for any and all issues, who purchased and distributed more than 400 birthday, sympathy, retirement, and appreciation cards to DGGS employees as well as providing hundreds of "thank you" and random gifts, just because it made her happy. Dedicated to providing a warm and supportive environment for DGGS employees, Paula routinely baked delicious treats for staff meetings and other special events for an estimated total of 200,000 calories, dished out over many years.

Paula was the public face of DGGS, consistently providing the highest quality customer care, which she demonstrated in everything from the careful layout of DGGS professional reports to timely and informative replies to public inquiries. She was present for the purchase of the first DGGS computer and oversaw the agency's transition to becoming a world-class online geologic data repository. Paula was highly respected and well-liked by all in the division. Having worked 30 years for the state, she was sought after for her impressive institutional knowledge and led by example.

A tireless and eagle-eyed editor, Paula ensured are our survey used proper grammer grammar, spelling, and capitalization for hundreds of DGGS' technical reports and map content. Now that her editing days are behind her, "Picky Paula" is enjoying time with her family and garden on the Washington coast and plans to travel the world during her retirement. Hopefully, she's growing Oxford commas, because goodness knows we could benefit from more of those!

Happy retirement, Paula! You are soarty sorely missed.

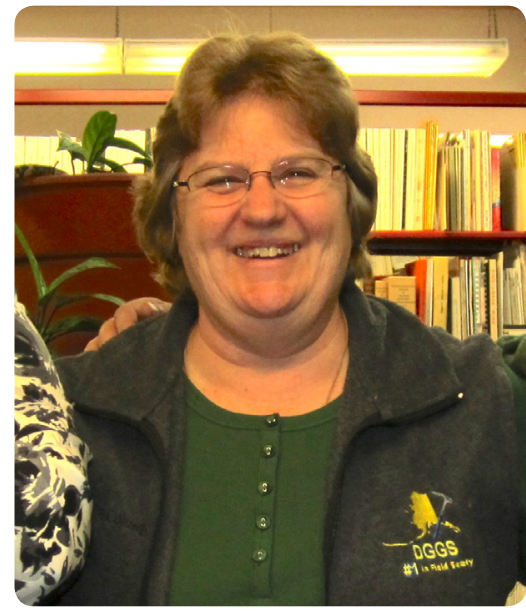

\section{Barbara (Bobby) Kirchner}

Bobby Kirchner was our division's Microcomputer/Network Technician I and tirelessly provided on-site computer hardware and software support for DGGS staff. Her dedication to the continued, successful operation of many of the computer resources and peripherals, and willingness to provide support in many other ways, was crucial to the division and its productivity.

Bobby was very much a solution-oriented person and had an impressive tenacity to research the problem until a solution was found. Due to recent budget cuts, her hours were unfortunately reduced down to 15 hours per week, despite a full-time workload. With the division's heavy dependence on computer resources, Bobby was constantly prioritizing tasks and seeking out efficiencies in the few hours she had to work. Regardless of the issue or her growing list of "trouble tickets," Bobby came to work each day with a positive attitude and genuinely enjoyed helping others within the DGGS "family."

Sadly, Bobby decided to retire in June, 2017. A month before leaving the survey, Bobby rescued one of our geologists (Dave LePain), whose computer literally blew up while in the throes of preparing a poster presentation and the handouts for a major scientific workshop. Within a few hours of the mishap (and after providing Dave with oxygen), she was able to provide back-ups of Dave's files so he could continue his meeting preparations on a field laptop, and was able to expedite the process of ordering a new desktop computer. Thanks to Bobby's prompt action, the computer arrived in time for Dave to finalize his poster and core workshop materials.

We are thankful that Bobby remained so diligent, courteous, and professional up to, and including, her last day with DGGS. Her patience and dedication to the survey and the state will be greatly missed.

Happy retirement, Bobby! 
DGGS STAFF

State Geologist's Office

Steve Masterman

State Geologist/Director

Kenneth Papp

Division Operations Manager/

Geologic Information Center

Section Chief

\section{Administration}

Shelly Showalter

Administrative Officer II/Section

Chief

April Woolery

Administrative Assistant III

Linda Natrop

Natural Resources Tech II

Energy Resources

David LePain

Petroleum Geologist I/Section

Chief

Robert Gillis

Geologist IV

Nina Harun

Geologist II

Trystan Herriott

Geologist III

Marwan Wartes

Geologist IV

Amanda Willingham

Geologist II

\section{Engineering Geology}

De Anne Stevens

Geologist V/Section Chief

Ronald Daanen

Geologist IV

Trent Hubbard

Geologist IV

Jacquelyn Overbeck

Geologist IV

Barrett Salisbury

Geologist IV

Gabriel Wolken

Geologist IV

Katreen Wikstrom Jones

Geologist I
Geologic Information Center

Kenneth Papp

Division Operations Manager/

Geologic Information Center

Section Chief

Patricia Gallagher

GIS Analyst III

Michael Hendricks

GIS Analyst III

Thomas Cerny

Micro/Network Tech II

Kristen Hendricks

Publications Specialist I

Simone Montayne

Geologist III

Susan Seitz

Analyst/Programmer IV

Ken Woods

Micro/Network Specialist II

\section{Geologic Materials Center}

Kurt Johnson

GeologistV/GMC Curator

Jean Riordan

Geologist III

Chris Ramey

Analyst/Programmer IV
Mineral Resources

Melanie Werdon

Geologist V/Section Chief

Abraham Emond

Geologist IV

Gina Graham

Geologist III

Jennifer Athey

Geologist IV

Karri Sicard

Geologist III

Evan Twelker

Geologist IV

Alicja Wypych

Geologist III

Volcanology

Janet Schaefer

Geologist V/Section Chief

Cheryl Cameron

Geologist V

Scott Crass

Analyst/Programmer IV

Katherine Mulliken

Geologist I

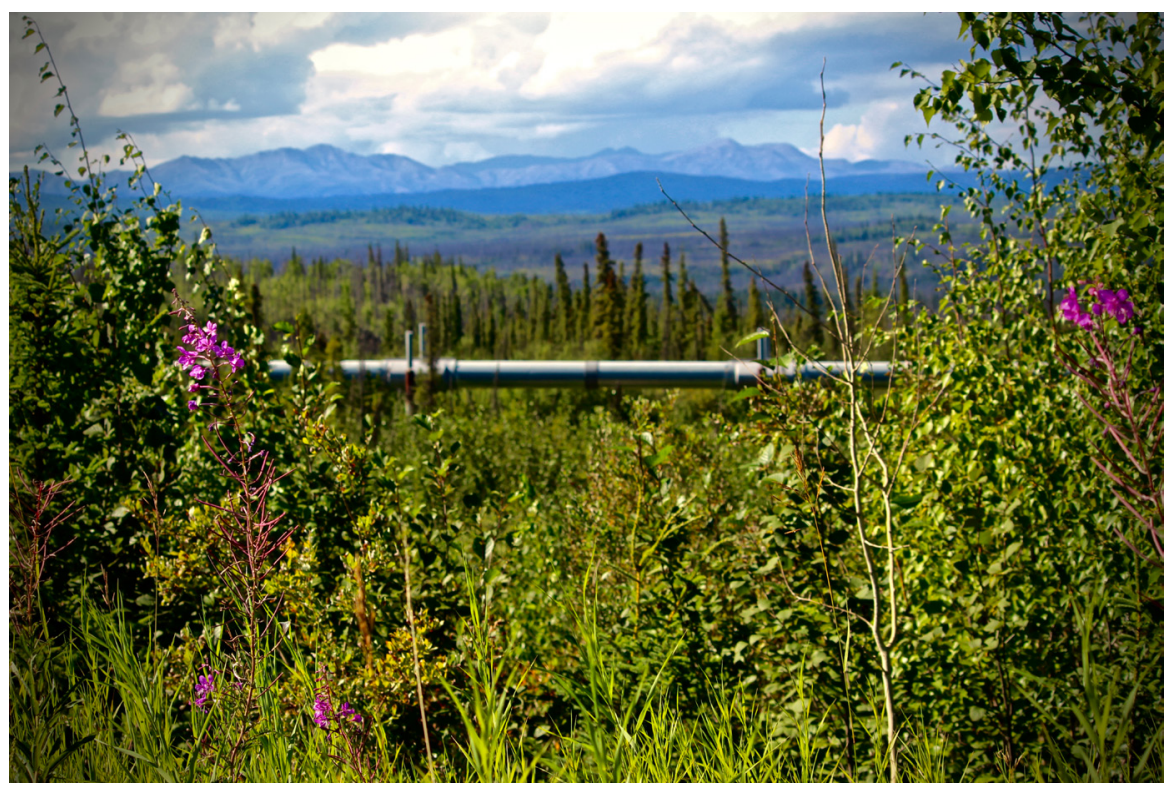



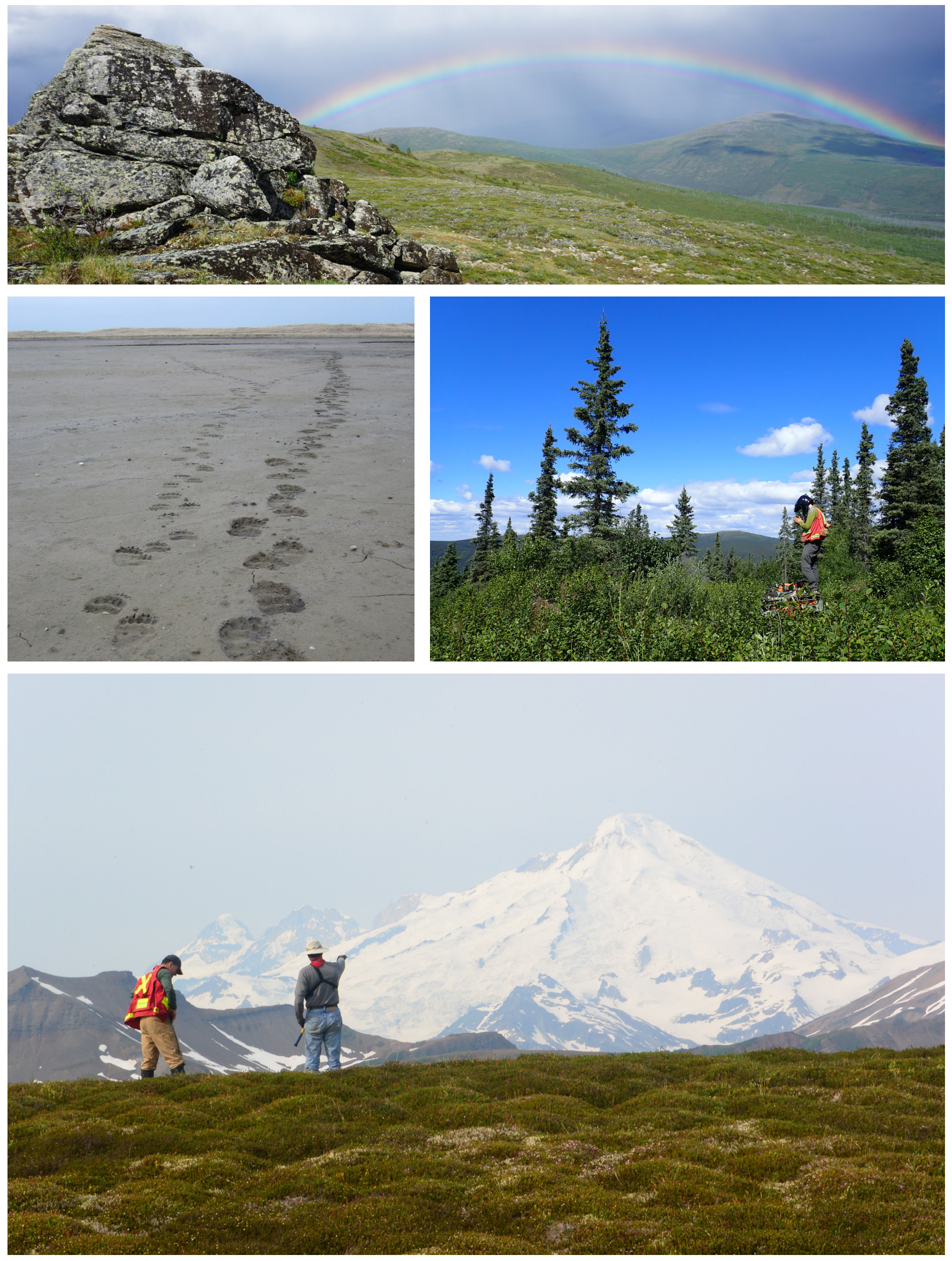